Florida International University FIU Digital Commons

FIU Electronic Theses and Dissertations

University Graduate School

6-29-2016

\title{
CFO Turnover, Firm's Debt-Equity Choice and Information Environment
}

Muhammad Bakhtear U. Talukdar

Florida International University, mtalukda@fiu.edu

DOI: $10.25148 /$ etd.FIDC000708

Follow this and additional works at: https://digitalcommons.fiu.edu/etd

Part of the Corporate Finance Commons, and the Finance and Financial Management Commons

\section{Recommended Citation}

Talukdar, Muhammad Bakhtear U., "CFO Turnover, Firm's Debt-Equity Choice and Information Environment" (2016). FIU Electronic Theses and Dissertations. 2618.

https://digitalcommons.fiu.edu/etd/2618

This work is brought to you for free and open access by the University Graduate School at FIU Digital Commons. It has been accepted for inclusion in FIU Electronic Theses and Dissertations by an authorized administrator of FIU Digital Commons. For more information, please contact dcc@fiu.edu. 


\section{FLORIDA INTERNATIONAL UNIVERSITY}

Miami, Florida

\section{CFO TURNOVER, FIRM'S DEBT-EQUITY CHOICE AND INFORMATION ENVIRONMENT}

A dissertation submitted in partial fulfillment

of the requirements for the degree of

DOCTOR OF PHILOSOPHY

in

BUSINESS ADMINISTRATION

by

Muhammad Bakhtear Talukdar

2016 
To: Acting Dean Jose M. Aldrich

College of Business

This dissertation, written by Muhammad Bakhtear Talukdar, and entitled CFO Turnover, Firm's Debt-Equity Choice and Information Environment, having been approved in respect to style and intellectual content, is referred to you for judgment.

We have read this dissertation and recommend that it be approved.

$\begin{array}{r}\hline \text { Abhijit Barua } \\ \hline \text { Ali M. Parhizgari } \\ \hline \text { Arun J. Prakash } \\ \hline \text { Arun Upadhyay } \\ \hline \text { Suchismita Mishra, Co-Major Professor } \\ \hline \text { Kannan Raghunandan, Co-Major Professor }\end{array}$

Date of Defense: June 29, 2016

The dissertation of Muhammad Bakhtear Talukdar is approved.

Acting Dean Jose M. Aldrich

College of Business

Andrés G. Gil

Vice President for Research and Economic Development and Dean of the University Graduate School

Florida International University, 2016 
C Copyright 2016 by Muhammad Bakhtear Talukdar

All rights reserved. 


\section{DEDICATION}

I would like to dedicate this dissertation to my lovely wife, Saima Sultana, my son, Zayan Bakhtear, my mother, Selina Serniyabat, and my brothers, Dr. Munir Talukdar, Adnan Talukdar, and Abir Talukdar. My special thanks goes to my wife, without whose continuous support during my graduate studies, it would have been difficult, if not impossible, to complete this work. 


\section{ACKNOWLEDGMENTS}

I would like to thank Dr. Suchismita Mishra, Dr. Kannan Raghunandan, Dr. Arun J. Prakash, Dr. Ali M. Parhizgari, Dr. Abhijit Barua, and Dr. Arun Upadhyay, members of my committee for their helpful suggestions and continued support. I would like to especially thank Dr. Arun J. Prakash for his valuable guidance and motivation that he provided throughout my doctoral study at FIU. I am also grateful to my family and my wife's family for their support. Without their support, motivation and consistent encouragement, this dissertation would not be possible. I would like to thank Dr. Golam Robbani, the Chair, Department of Finance and Economics at Alabama A\&M University for referring FIU for my PhD and his kind guidance during my study. My special thanks go to my friend Dale DeJong for his help and support during my dissertation. Dr. Jianbin Zhu at the Statistical Consulting at UGS has always been a phenomenal help in untangling SAS codes, my appreciation for his kind help. Last but not least, my deep gratitude to my adviser, Dr. Suchismita Mishra for her endurance, patience and kindness. She treated me as more than a PhD student, she was always there for me whether it be for reading my dissertation, providing useful feedback, writing letters of recommendation, and the list goes on. Without her kind support, this dissertation would not be to the high standard that it is now. 


\section{ABSTRACT OF THE DISSERTATION \\ CFO TURNOVER, FIRM'S DEBT-EQUITY CHOICE AND INFORMATION \\ ENVIRONMENT}

by

Muhammad Bakhtear Talukdar

Florida International University, 2016

Miami, Florida

Professor Suchismita Mishra, Co-Major Professor

Professor Kannan Raghunandan, Co-Major Professor

The CEO and CFO are the two key executives of a firm. They work cohesively to ensure the growth of the firm. After the adoption of the Sarbanes Oxley Act (SOX) in 2002, the importance of CFOs has increased due to their personal legal obligation in certifying the accuracy of financial statements. Only a few papers such as Mian (2001), Fee and Hadlock (2004), and Geiger and North (2006) focus on CFOs in the pre-SOX era. However, a vacuum exists in research focusing exclusively on CFOs in the post-SOX era. The purpose of this dissertation is to delve into a comprehensive investigation of the CFOs. More specifically, I answer three questions: a) does the CEO change lead to the CFO change? b) does the CFO appointment type affect the firm's debt-equity choice? and c) does the CFO appointment affect the firm's information environment?

I use Shumway's (2001) dynamic hazard model in answering question 'a'. For question 'b', I use instrumental variable (IV) regression under various estimation techniques to control for endogeneity. For part 'c', I use the cross sectional difference-in- 
difference (DND) methodology by pairing treatment firms with control firms chosen by the propensity scores matching (PSM).

I find there is about a $70 \%$ probability of CFO replacement after the CEO replacement. Both of their replacements are affected by prior year's poor performance. In addition, as a custodian of the firm's financial reporting, the CFO is replaced proactively due to a probability of restatement of earnings. I find firms with internal CFO hires issue more equity in the year of appointment than firms with external hires. The promoted CFO significantly improves the firm's overall governance which helps the firm obtain external financing from equity issue. However, I find that CFO turnover does not significantly affect the firm's information environment. To ensure that my finding is not due to mixing up of samples of good and distressed firms together, I separated distressed firms and re-ran my models and my finding still holds.

This dissertation fills the gap in the literature with regards to CFOs and their post SOX relationship with the firm. 


\section{TABLE OF CONTENTS}

CHAPTER

PAGE

1. DOES THE CEO CHANGE LEAD TO THE CFO CHANGE? .....................................

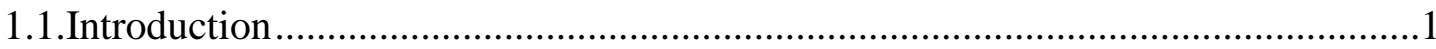

1.2.Literature Review and Development of Hypotheses..............................................6

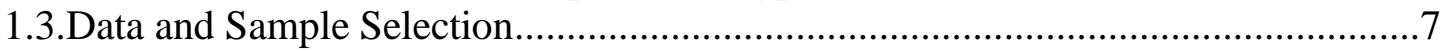

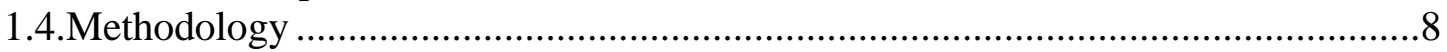

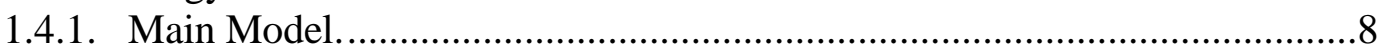

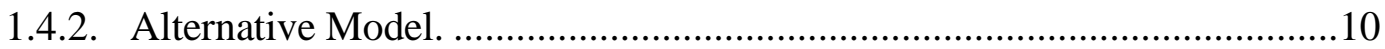

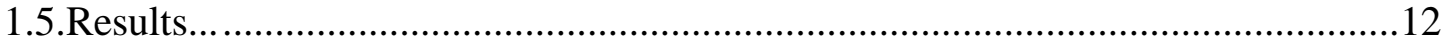

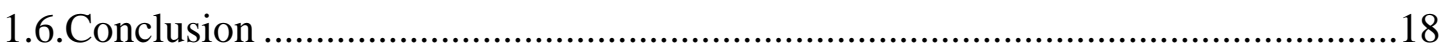

2. DOES THE CFO APPOINTMENT TYPE AFFECT THE FIRM'S DEBT-EQUITY

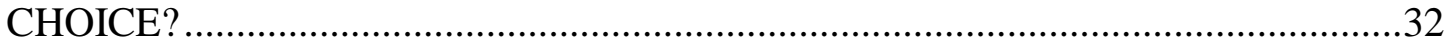

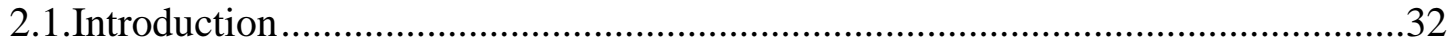

2.2.Literature Review and Development of Hypotheses...............................................38

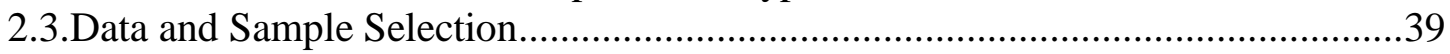

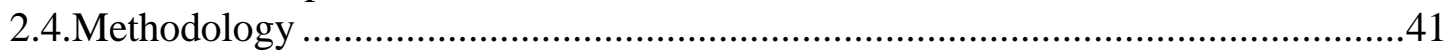

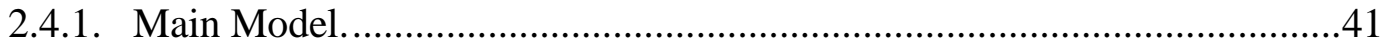

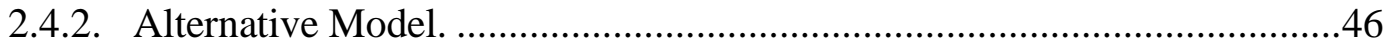

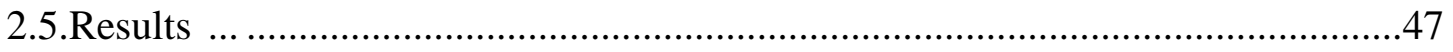

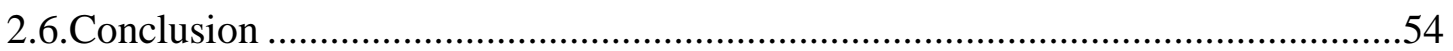

3. DOES THE CFO APPOINTMENT AFFECT THE FIRM'S INFORMATION

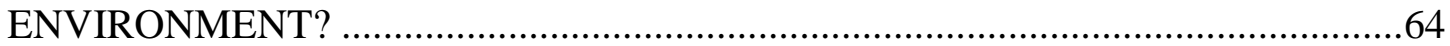

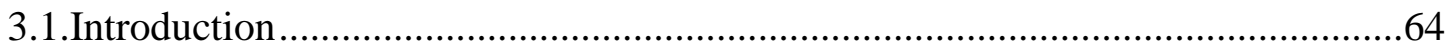

3.2.Literature Review and Development of Hypotheses..............................................69

3.2.1. Information Environment and CFO Change .........................................69

3.2.2. Information Environment Proxies.........................................................72

3.2.3. Testable Hypotheses ………………………........................................ 72

3.3.Data and Sample Selection...........................................................................

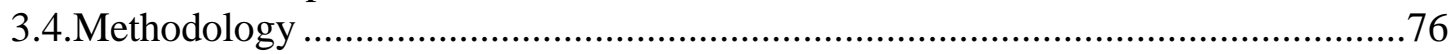

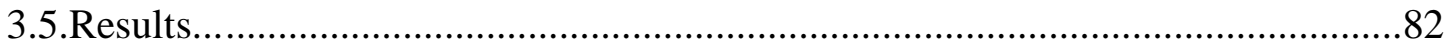

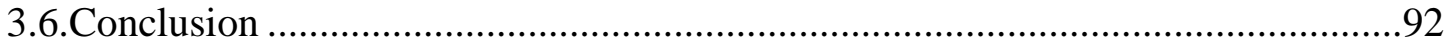

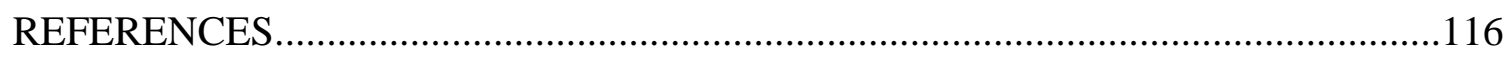

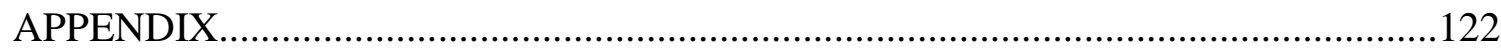

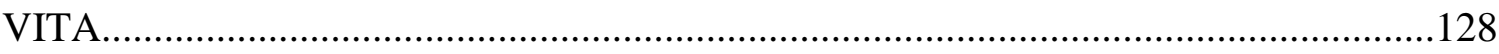




\section{LIST OF TABLES}

TABLE

PAGE

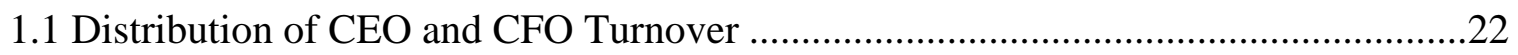

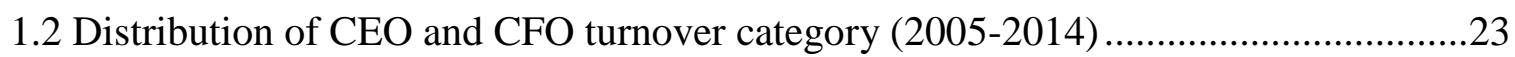

1.3 Descriptive Statistics (Full Sample)...............................................................24

1.4 Descriptive Statistics (CEO-CFO Changed Years) ............................................25

1.5 Calculation of F-score following Dechow, Ge, Larson, and Sloan (2011)................26

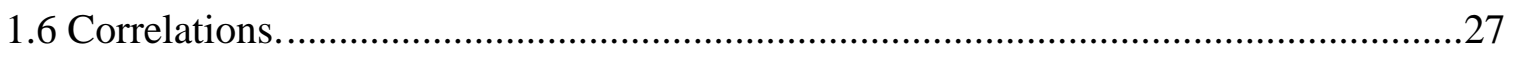

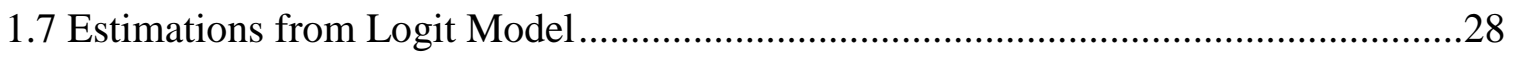

1.8 Estimation from Fixed Effect Logit Model .....................................................29

1.9 Estimation from Dynamic Hazard Model ........................................................... 30

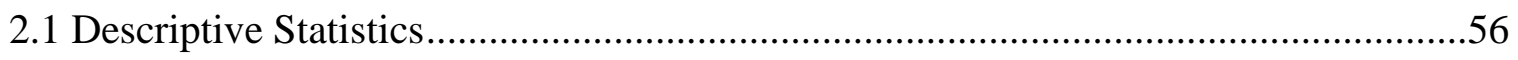

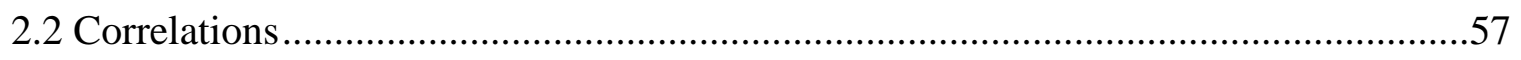

2.3 Debt-equity Choice by Internal and External CFOs ........................................58

2.4 T-test on Other Variables between Two Groups .................................................59

2.5 Effect of Internal CFO on Governance and Equity Issue ....................................60

2.6 Internal CFO and Firm Equity Choice .........................................................61

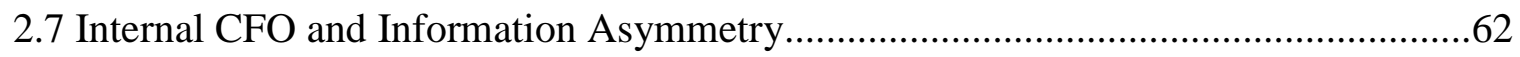

2.8 Internal CFO and Firm Equity Choice (Probit Model) ......................................63

3.1 Definition of Information Environment Variables ...............................................97

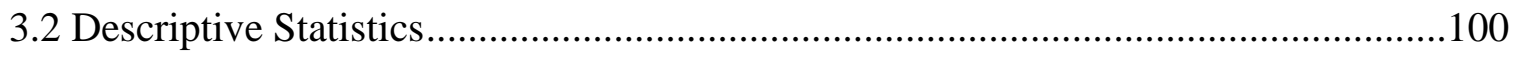

3.3 T-test of Information Environment Variables................................................. 102

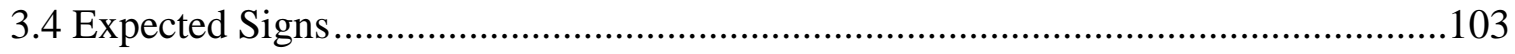


3.5 Multivariate Analysis (All Firms) 104

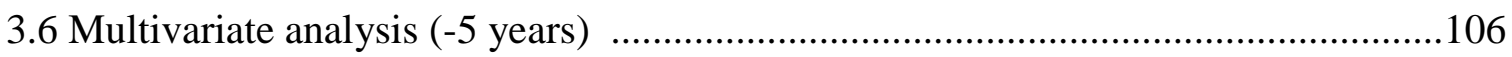

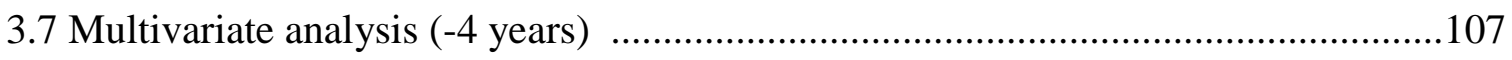

3.8 Multivariate analysis (-3 years) ………………................................................108

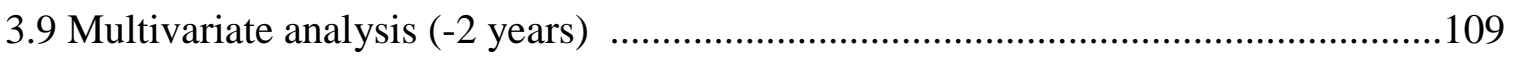

3.10 Multivariate analysis (-1 year) …………………..........................................110

3.11 Multivariate Analysis for Internal CFO Appointment (All Firms) ..........................111

3.12 Multivariate Analysis for External CFO Appointment (All Firms) ........................112

3.13 Multivariate Analysis for External CFO Appointment (-5 Years) ..........................113

3.14 Multivariate Analysis for External CFO Appointment (-4 Years) .........................114

3.15 Multivariate Analysis for External CFO Appointment (-3 Years) .........................115 


\section{LIST OF FIGURES}

FIGURE

PAGE

1.1 Spike of CFO Turnover following CEO Turnover ....

1.2 CEO \& CFO Turnover.

2.1 Why I have defined internal CFO as having year-difference is $>=2$ years..................55

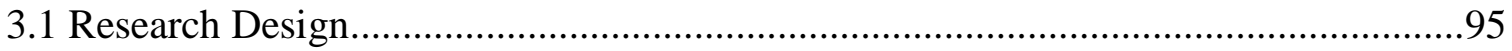

3.2 Comparison between institutional holding (block holding by outsiders) of a group of firms in 1996-2001 with institutional holding of the same group of firms in 2005-2011. 


\section{CHAPTER 1: DOES THE CEO CHANGE LEAD TO THE CFO CHANGE?}

\subsection{Introduction}

The Chief Executive Officer (CEO) is the central point of many governance and earnings management literature ${ }^{1}$. Some research looks into the dynamic relationship between the CEO and the CFO (Chief Financial Officer), due to the growing importance of the $\mathrm{CFO}$ as second in command in terms of financial reporting after the adoption of the Sarbanes Oxley Act (SOX) of $2002^{2}$. Coyne and Coyne (2007) find that one out of four proxy-level executives had to leave the firm within a year of the CEO taking charge following SOX. Moreover, Fee and Hadlock (2004) find that non-CEO departure spiked significantly after the new CEO took office (within six months) in their sample period. They argue that the board and/or the new CEO cleans out the old management team fairly quickly when the old CEO is dismissed. My objectives in this essay are twofold. First, the purpose is to investigate whether the pre-SOX finding on the CEO-CFO turnover relation (i.e., following the CEO turnover there is a spike of non-CEO turnover) remains in the post SOX. Second, the aim is to investigate whether the CEO departure can be an opportune moment for the CFOs to take over his/her (earlier) boss's position. The likelihood of accounting restatement and receiving adverse SOX 404 opinions depends on the ability of the CFO. Aier et al. (2005) show that restatement is negatively associated with the CFO's

\footnotetext{
${ }^{1}$ For example, see McAnally, Weaver, and Srivastava (2008), Graham and Harvey (2001), Parrino (1997), and Jiang, Petroni, and Wang, (2010).

${ }^{2}$ Hayes et al. (2002), and Fee and Hadlock (2004) take a broader perspective in modeling CEO and non-CEO manager turnover.
} 
financial expertise. Li et al. (2010) show that prior years' adverse auditor opinion can be removed by hiring a $\mathrm{CFO}$ with better qualifications.

Moreover, financial background is the most valued tenet to become the CEO. A Forbes magazine study shows that about $30 \%$ of the Fortune 500 CEOs spent the first few years of their careers in developing a strong background in finance ${ }^{3}$. After the debacle of Enron (October 2001) and at the wake of WorldCom's (June 2002) accounting fraud ${ }^{4}$, the US Congress passed the SOX in July 2002. Both the CEO and CFO of WorldCom escaped from the Congressional hearing, citing their Fifth Amendment rights. Section 302 of SOX separates the $\mathrm{CEO}$ and the $\mathrm{CFO}$ from the rest of the executive team and distinguishes them by assigning personal legal responsibility in ensuring the accuracy of financial statements ${ }^{5}$. Jiang et al. (2010) argue that "Because CFOs' primary responsibility is financial reporting, CFO equity incentives should play a stronger role than those of the CEO in earnings management (p. 513)." They show that "the magnitude of accounting accruals and likelihood of beating analyst forecasts are more sensitive to CFO equity incentives than to those of the CEO (p. 513)." The growing importance of the CFO in the organizational

\footnotetext{
${ }^{3}$ Financial expertise is by far the most common early experience of CEOs, followed by sales and marketing. The full study is available at http://www.forbes.com/sites/ciocentral/2011/12/05/the-path-to-becoming-afortune-500-ceo/\#5400b64b28c9.

${ }^{4}$ WorldCom mislabeled the current expenses (income statement item) of line-fees for accessing third parties' telephone lines as the long-term assets (balance sheet item) and therefore, had shown inflated net income and increased assets. For the full story on WorldCom: The Accounting Scandal, please refer to: http://www.law.umaryland.edu/marshall/crsreports/crsdocuments/RS21253_08292002.pdf

${ }^{5}$ From section 302 of the Sarbanes-Oxley Act of 2002, "The Commission shall, by rule, require, for each company filing periodic reports under section 13(a) or 15(d) of the Securities Exchange Act of 1934 (15 U.S.C. $78 \mathrm{~m}, 78 \mathrm{o}(\mathrm{d})$ ), that the principal executive officer or officers and the principal financial officer or officers, or persons performing similar functions, certify in each annual or quarterly report filed or submitted...." For the complete text please refer to: https://www.sec.gov/about/laws/soa2002.pdf.
} 
structure motivates me to look into the causal relation between the $\mathrm{CEO}$ and $\mathrm{CFO}$ turnover ${ }^{6}$.

When a firm faces the need to implement a new strategy especially after a spell of poor performance, it replaces its current CEO to make a 'turnaround'. New CEOs significantly change the status quo of current operations and bring massive changes into the firm's policies and strategies. As found by Weisbach (1995), the probability of unprofitable divestment of acquisitions that were done at the time of previous CEOs increases significantly after a new CEO takes office. Moreover, Huson et al. (2004) find that firm performance prior to appointing a CEO deteriorates and improves after the appointment of a new CEO. Therefore, CEO change is an important event in a firm's life, and it is worthwhile to see how non-CEO executives/managers are affected by such a change.

Fee and Hadlock (2004) find that the association between CEO and non-CEO executive turnover is driven by the CEO departure followed by poor performance. However, performance alone cannot predict non-CEO executive departure. Moreover, they find when CEOs are replaced from the external labor market, the departure of non-CEO managers jumped within the first six months of such replacement. Fee and Hadlock use data from the 1990s and sample firms from the S\&P 500 index. Their findings may be biased due to firm size because the S\&P 500 only includes big firms in the index. Moreover, in their sample period, the $\mathrm{CFO}$ was not a big figure in the executive team; therefore, Fee and Hadlock (2004) do not distinguish the CFO vs. other executives. After SOX, the CFO

\footnotetext{
6 "Turnover," "change," and "replacement" are used interchangeably in this paper.
} 
has been getting more importance in the press as well as in academic literature. A comprehensive analysis of the replacement of the CEO and CFO, the top two executives of the firm, and the reason(s) behind such replacement are an interesting phenomenon in corporate governance literature.

There are only a few papers (Parrino, 1997; Mian, 2001; Fee and Hadlock 2004), which analyze non-CEO executive replacement surrounding CEO replacement. However, they differ broadly in their methodologies and dimensions in analyzing the relation between CEO turnover and non-CEO departures. For example, in Mian's (2001) paper, a $t$-test between CFO turnover 'before' and 'after' CEO replacement establishes a clear association between CEO change and CFO replacement. In addition, Parrino (1997) compares forced and voluntary turnover of former CEOs with replacement from inside the organization (via promotion) and outside the organization. Like Mian (2001), he employed a $t$-test between two proportions and concluded that in the case of forced turnover, outside replacement is evident. Unlike Mian (2001) and Parrino (1997), Fee and Hadlock (2004) employed multinomial logit model and from related coefficients, they derived the implied probability, which produces a percentage of an event happening. For example, they find in the normal case (defined as "in the case when CEO is not fired") the non-CEO manager turnover rate is $9.28 \%$, however, this rate jumps to $21.03 \%$ if the CEO leaves the office last year or this year for reasons (or the CEO is fired) other than health, death, corporate control transactions, and pursuit of their career to other companies. For only forced turnover, the corresponding rates are $2.85 \%$ and $13.50 \%$, respectively. However, as I mentioned earlier, their findings are based on S\&P 500 firms, and the sample period is quite a long time ago (1993-1998). 
I find that the $\mathrm{CEO}$ change causes the $\mathrm{CFO}$ change. There is approximately an $82 \%$ probability of CFO replacement after the CEO has been replaced. There is about a $69 \%$ probability of $\mathrm{CFO}$ turnover when the $\mathrm{CEO}$ is replaced due to prior years' poor performance. However, this rate jumps to $79 \%$ when there is both CEO replacements due to poor performance and a likelihood of accounting restatements. These are the results from Shumway's (2001) Dynamic Hazard Model. As an overseer of a firm's financial reporting, the CFO is replaced proactively due to a probability of the restatement of earnings. I use F-score (see Dechow et al. 2011) to calculate the likelihood of accounting restatement. I use various specification and estimation techniques in the robustness process. I use logit model in this study. Also, I use the dynamic hazard model and the firm and year fixed effect logit model using all years (including both the CEO-CFO and non-CEO-CFO change years). My findings hold across all these various models.

I contribute to the existing literature in four ways. First, in addition to re-confirming the pre-SOX finding that CEO turnover causes non-CEO turnover, I show that CEO resignation can be a career opportunity for the CFOs. Second, relative to existing literature, my study is based on a newer data set and involves the post-SOX era. Third, while previous studies drew conclusions based on event study or $t$-statistic, I use an advanced model with strong probabilistic inference ability to predict the CFO change surrounding the CEO change. Indeed, the validity of the statistical conclusion based on $t$-statistic may sometimes be confounding as argued by Soyer and Hogart (2012) “... There was widespread confusion in the interpretation of statistical results, due to a confounding of the concepts of statistical and economic or substantive significance. Too many results depended on whether the $t$ - or other statistics exceeded arbitrarily defined limits (p. 697)," (see also 
McCloskey and Ziliak [1996]). Finally, I focus on the CFO and CEO turnover relationship under various action categories: appointment, dismissal and resignation. The importance of the $\mathrm{CFO}$ as the second person in charge is increasing day by day, thus, focusing $\mathrm{CFO}$ and CEO turnover relationship and modeling it through the accurate probabilistic inference ability adds value to the existing literature.

\subsection{Literature Review and Development of Hypotheses}

Mian (2001), Parrino (1997), and Fee and Hadlock (2004) add to the design of my research questions. Since the CEO is the main person to evaluate the performance of nonCEO executives, it is natural to expect when the CEO is replaced, he or she brings changes to the team they will be working with. Thus, my first hypothesis deals with the central question of my research: whether CEO replacement brings change to his/her CFO?

Hypothesis-1: The CEO change leads to the subsequent CFO change within a year. Forced versus voluntary departures are interesting dimensions of executive turnover research (see Hayes et al., 2002, Parrino, 1997; Jalal and Prezas, 2012). In the cases of a CEO's voluntary turnover (such as resignation), the CFO may have an opportunity for a career jump and may take over his/her previous boss's position (CEO). In the cases where CEOs are ousted (due to dismissal or employment ceased) from their positions, it can be expected that the firm may also want to remove the second-in-command in terms of financial reporting, the CFO. Hazarika et al. (2012) show that forced turnover of CEOs is positively related with the firm's earnings restatement. In addition, they find that earning management is positively related with the CFO's forced removal. Therefore, in the case of earning restatements, firms may fire either the $\mathrm{CEO}$ or $\mathrm{CFO}$ or both. I posit that, 
Hypothesis-2A: Voluntary turnover of CEOs creates a career opportunity for CFOs.

Hypothesis-2B: Involuntary turnovers of CEOs instigate involuntary turnovers of CFOs.

\subsection{Data and Sample Selection}

I take $\mathrm{CEO}$ and $\mathrm{CFO}$ turnover data from AuditAnalytics ${ }^{7}$ (AA). Variables used for calculating F-score (Dechow et al., 2011) are taken from COMPUSTAT. Stock market returns data are collected from CRSP (Center for Research in Security Prices). Although AA shows that it has data since 1999, there is only a few observations in 1999-2002, 10 CEO turnovers and 4 CFO turnovers. In 2004, the U.S. Securities and Exchange Commission was finalizing the rulings regarding $8-\mathrm{K}$ filings and the effective date of the Final Rule ${ }^{8}$ was August 23, 2004. Moreover, data are still being collected on firms that have fiscal year ended in the later part of 2015. Therefore, I excluded 2004 and 2015. My sample period covers 2005-2014, a decade of full-year data. Following accounting and finance literature, I excluded firms from regulated and financial industries (SIC 4900-4999 and 6000-6900) and excluded firms that have had total assets less than ten million. I label "Full Sample" for all firms including four major sub-samples: "Appointed," "Resigned," "Dismissed," and "Employment Ceased." I take these categories from AuditAnalytics which define them as follows:

Appointed - indicates an engagement, appointment, election to Board, etc.

\footnotetext{
${ }^{7}$ Please refer to http://www.auditanalytics.com/

${ }^{8}$ Please refer to https://www.sec.gov/rules/final/33-8400.htm
} 
Dismissed - indicates a clear involuntary termination of employment or board service

Resigned - indicates a voluntary departure.

Employment Ceased - used when the filing is unclear as to whether the departure was voluntary or involuntary.

I combined dismissed and employment ceased and label them as an involuntary turnover. Also, I label resigned as a voluntary turnover. The reason I included resigned as the subsample is sometimes firms do not want to fire a CEO or CFO but rather give them options to leave on their own. Firing is bad news for the fired executives as well as for the firms. Fired executives have a hard time finding a similar or better job. Gilson (1989) studies managers' turnover from financially distressed firms. He finds it takes three years for the resigned managers to be employed by a similar firm. Also, the board does not want to associate itself with firing because of board members personal reputational risk (Taylor 2010). I winsorize all variables (except dichotomous variables) at $1 \%$ and $99 \%$ level.

The number of observations across models are different due to: a) using a sub-set of full sample, b) using more variables into some model than others, and c) not all variables having the data for the same years. I mention the number of observations (NOBS) used in the models in the result tables.

\subsection{Methodology}

\subsubsection{Main Model}

My objective in this essay is to predict the possibility of CFO turnover within a year surrounding CEO turnover. A firm qualifies to be included in the sample when it experiences CFO turnover in any particular year and/or CEO replacement. I am taking the 
post-year of CEO replacement because Hayes et al. (2002) find that the association between $\mathrm{CEO}$ and non-CEO changes persists i.e., non-CEO managers are more likely to leave the company's top management team even the year after CEO turnover. In line with Fee and Hadlock (2004), I use the following model to define CFO turnover as a function of the prior year's CEO turnover with other specified controls:

$$
\begin{aligned}
& \text { CFOturnover }_{i, t}=\text { CEOturnover }_{i, t-1}+\text { Return }_{i, t-1}+\text { LnofSales }_{i, t}+\text { CEO }_{i, t} \\
& \text { Return }_{i, t-1} \\
& \text { F } \text { score }_{i, t}+e_{t}
\end{aligned}
$$

CFOturnover $_{i, t}$ is CFO turnover for firm $i$ in year $t$ and CEOturnover ${ }_{i, t-1}$ is CEO turnover for firm $i$ in the prior year, respectively. Return $_{i, t-1}$ is the "firm's buy-and-hold stock return for the period ending at the start of the fiscal year during which the departure takes place less the value-weighted 2-digit compounded monthly industry return over this same period" (Fee and Hadlock, 2004, p.14). LnofSales $i, t$ is natural log of sales. The interaction term, CEOi, $*$ Return ${ }_{i, t-1}$ is for capturing the effects of CEO being fired for poor performance. Fscore $i, t$ is the probability of the firm's earnings restatements. Because both sales and F-score are internal mechanisms for the board to monitor managers, I calculate both of them for the current year. Hazarika et al. (2012) show that boards tend to act proactively to discipline managers by firing managers before accounting restatement happens. F-score is calculated following Dechow et al. (2011) and using the logit regression which takes the following form:

$$
\begin{aligned}
& \pi(\text { Restatement }=1)=f(\text { RSSTaccruals }+\Delta \text { inReceivables }+\Delta \text { inInventories }+ \\
& \text { SoftAssets }+\Delta \text { inCashSales }+\Delta i n R O A+\Delta \text { inEmployees }+ \text { LeaseDummy }+ \\
& \text { IssueDummy }+u_{t}
\end{aligned}
$$


In order to calculate the F-score, the predicted restatement from the above equation is divided by the unconditional probability ${ }^{9}$. Unconditional probability is defined by dividing the total number of accounting restatements by the total number of sample firms including the restated firms. An F-score equal to 1.00 means the firm has the same probability of restating earnings as unconditional probability. The higher F-score than 1.00 means firms have higher probability of restating earnings. For example, an F-score of 2.00 means firms have twice the probability of restating earnings compared to a randomly selected firm from the sample. The variable definitions are given in the appendix.

I use the logit regression for equation (1). Also, I use the (firm and time) fixed effect logit regression. Both the logit regression and the fixed effect logit regression give an estimated probability effect of independent variables on the dependent variable. However, the latter model adjusts for variability due to time and variability caused by changes in the firm characteristics over time. I use both specifications for all firms and three sub-samples.

\subsubsection{Alternative Model}

Like extant research, I use the logit model in which the dependent variable is dichotomous (taking a 0 or 1 as response). However, Shumway (2001) shows that a static logit model is not a better predictor model, especially when data are time series and a firm's characteristics change over time. Therefore, he suggests a more dynamic hazard model. A static logit model only considers the firm-year of the event, whereas a hazard model considers each firm year observation. Therefore, it is more efficient than logit (or multinomial choice model) in out-of-sample forecasts. Davidson et al. (2013) use a more

\footnotetext{
${ }^{9}$ Dechow et al. (2011) scale their negative predicted restatement by using EXP(predicted restatement)/1+ EXP(predicted restatement). However, in my case, all the predicted values are positive and therefore, I did not have to use the conversion.
} 
dynamic hazard model and point out two major benefits of the model over a static logit model: a) it overcomes sample selection biases which may arise from only one nonrandomly selected observation per firm, and b) incorporates the time-varying nature of the predictor variables. The following discussion is heavily based on Shumway (2001) who first shows the superiority of a hazard model over a (static) logit model.

A logit model is from a group of static models which has the following likelihood function,

$$
\mathcal{L}=\prod_{i=1}^{n} F\left(t_{i}, x_{i} ; \theta\right)^{y_{i}}\left[1-F\left(t_{i}, x_{i} ; \theta\right)^{1-y_{i}}\right]
$$

Where, $\mathrm{F}$ is a cumulative density function (CDF) which corresponds to $f(t, x ; \theta)$. The hazard model requires a few more definitions than the above function. The survivor function (gives the probability of surviving up to time $t$ ) and the hazard function (gives the probability of failure at time $t$ conditional on surviving up to time $t$ ) take the following forms, respectively:

$$
\begin{gathered}
S(t, x ; \theta)=\sum_{j<t} f(j, x ; \theta) \\
\varphi(t, x ; \theta)=\frac{f(t, x ; \theta)}{S(t, x ; \theta)}
\end{gathered}
$$

The hazard model has the following likelihood function,

$$
\mathcal{L}=\prod_{i=1}^{n} \varphi\left(t_{i}, x_{i} ; \theta\right)^{y_{i}} S\left(t_{i}, x_{i} ; \theta\right)^{1-y_{i}}
$$


"The hazard model can incorporate time-varying covariates by making $x$ depend on time" (Shumway, 2001, p. 105).

To calculate implied probability or odds for each co-variate I use the following formula $^{10}$,

$$
\text { Probability }=\frac{\text { Hazard Ratio }}{1+\text { Hazard Ratio }}
$$

In addition, I also run the firm and time fixed effect model to purge out any effect that is due to the firm's characteristics and time.

\subsection{Results}

Table 1.1 reports the distribution of CEO and CFO turnovers. In total, there were 9,773 turnover events. CFO turnovers were 5,499 and 4,337 CEO turnovers. In all years, CFO turnover is more than CEO turnover. The highest turnover happened in 2007: 496 CEO turnovers and 708 CFO turnovers. The year 2006 had the second highest for both the CEO turnover (485 turnovers) and the CFO turnover (698 turnovers). Figure 1.1 shows the spike of the CFO turnover following the CEO turnover for "Full Sample" and under "Voluntary Turnover" and "Involuntary Turnover." Figure 1.2 shows the CEO-CFO turnover distribution. CFO turnover followed the CEO turnover in the sample period: 20052014. Financial crisis had a greater toll on CFOs than CEOs as more CFOs were replaced or laid off during 2008-2009 (noticeable decline in CFO line from 2008 to 2009).

\footnotetext{
${ }^{10}$ The same conversion formula is used by Spruance et al. (2004). See Antimicrobial Agents and Chemotherapy, Aug. 2004, p. 2787-2792.
} 
Table 1.2 includes turnover categories by "action" field in AuditAnalytics (AA). The "action" field categorizes all turnover events by recent change that has taken place or will take place in the $\mathrm{CEO}$ or $\mathrm{CFO}$ title. AA defines it as follows:

"This field describes the action that describes the change that has taken or will take place, i.e., an appointment, resignation, dismissal, etc. For the most part, the action that is indicated is what is stated in the filing, unless it is very clear that the filing says one thing, but means another. For instance, if the filing states that a director's resignation from the board was required as part of a settlement to end a lawsuit, the action would be graded as a dismissal."

The most action category is "appointed" (frequency is 5,962 and 58.30\% of total turnover events), and the least are "declined re-election" or "nominated." In my sample, I excluded generic retirements and those deceased, which are 687 events and 23 events, respectively. In my sub-sample analysis, I use "Resigned" as voluntary turnover and "Dismissed" and "Employment Ceased" together as involuntary turnover which have 2,650 and $644(=150+494)$ events, respectively.

Table 1.3 reports the descriptive statistics using all firm-year data including CEO and $\mathrm{CFO}$ turnover years. For a firm that has experienced $\mathrm{CEO}$ and/or CFO replacement in any year in 2005-2014 is included in the sample assuming the firm was established before 2005. There is 10 years of data. The buy-and-hold market adjusted return is positive $(=12.10 \%)$, however, the interaction of return with the CEO is negative $(=-0.90 \%)$, which means that CEO replacement is associated with poor firm performance. RSST accruals stand for Richardson, Sloan, Soliman, Tuna accruals. I follow Richardson et al. (2005) to calculate the accruals. Soft assets are the ratio of total assets, except PP\&E, cash, and cash 
equivalents to total assets. About half (=mean is 0.49 ) of the firm's assets are composed of soft assets. Change in number of employees is negative ( $=-5.00 \%)$, which implies that over the time firms reduced their employee base. Lease dummy and issue are indicator variables. Lease dummy takes a value of 1.00 for existence of operating lease, and issue takes a value of 1 , if the firm issues either debt or equity in the sample period. In both cases, over $70 \%$ of the firms have existence of operating lease and issue either debt and/or equity. Year is a trend variable, which takes a value of 0-10 (e.g., 2005-2005=0 and 2014-2005=10).

Table 1.4 reports the descriptive statistics only for the firms which experienced either CEO or CFO or both turnovers. These are sub-section of firms reported in Table 1.5. Overall, the results are similar with few exceptions: a) the likelihood of restatement is higher (1.02 versus 0.98$), b)$ the changes in ROA is more negative (-1.30\% versus $-0.50 \%)$, and c) the proportion of firms with operating lease obligations is higher (91\% versus $78 \%$ ).

Table 1.5 reports one of the key variables I use in my study-F-score. F-score is a parsimonious way of identifying the probability of a firm to restate its earnings. I take this measure from Dechow et al. (2011). Panel-A reports the maximum likelihood estimation from logistics regression. The important determinants for earnings restatement are accruals (like Dechow et al., I take accruals from Richardson et al. 2005), soft assets, changes in cash sales, changes in employees, existence of operating lease, existence of debt or equity. Panel-B reports the overall model fit statistics using three information criteria: AIC (Akaike information criterion), SC (Schwarz criterion) and $-2 * \log$ likelihood ratio. My results are similar to that of Dechow et al. (2011), except my change in cash sales is negatively impacting restatement, whereas in the reference paper of Dechow et al. (2011) it is positive. In both cases, intercept is negatively significant. The three criteria tell us the 
validity of the covariates used in the logistic regression. AIC and $-2 * \log$ likelihood ratio are lower when covariates are added to the intercept, which implies that the covariates significantly (refer to Panel-C) improve the model. Generally speaking, information criteria are used to pick the best model among competing models.

Table 1.6 reports correlations between the variables both dependent and independent. I am specifically interested in the correlation between last year's CEO turnover and this year's CFO turnover. The correlation between these two variables is 0.246 and significant at $<0.0001$ level. Moreover, earlier research shows that poor performance is responsible for firing managers. I use last year's industry adjusted returns ${ }^{11}$ for poor performance and multiplied it by this year's CEO turnover. The product has a significant positive correlation $(=0.026$ significant at $<0.0001$ with the $\mathrm{CFO}$ turnover, which means that both $\mathrm{CEO}$ and $\mathrm{CFO}$ can be replaced for the poor performance. F-score is a probabilistic estimate for accounting restatement. It has a positive correlation $(=0.067$ significant at 0.0001 ) with $\mathrm{CFO}$ turnover, which means that the higher the probability of accounting restatement, the higher the chance that the CFO would be replaced.

Table 1.7 includes the output from logit model. The second column includes all the firm-year irrespective of the categories. Column 3 and 4 report subsample analysis for voluntary (=resigned) and involuntary (=dismissed and employment ceased) turnover category, respectively. The dependent variable in all three settings is CFO turnover (=all categories) for this year, voluntary (=resigned) for this year, and involuntary (=dismissed and employment ceased) for this year. The variable of interest is the prior year's CEO

\footnotetext{
${ }^{11}$ Return is defined as "firm's buy-and-hold stock return for the period ending at the start of the fiscal year during which the departure takes place less the value-weighted 2-digit compounded monthly industry return over this same period (Fee and Hadlock 2004, p.14)."
} 
turnover. In "Full Sample" and "Voluntary Turnover" models, the prior year's CEO turnover significantly affects this year's CFO turnover. The coefficient for the $\mathrm{CEO}_{\mathrm{t}-1}$ is significant and negative for the voluntary (=resigned) turnover. This means that firms most probably have a succession plan for the leaving CEOs and they prepare CFOs to take over. The CEO resignation is a career opportunity for the CFO. Like correlation, the interaction term $\left(=\mathrm{CEOt}^{*}\right.$ return $\left._{\mathrm{t}-1}\right)$ has a significant positive affect on the CFO turnover. Fee and Hadlock (2004) use this variable and show that for negative performance, CEOs are penalized before any other executive.

F-score implies the likelihood of accounting restatement has a positive impact on CFO turnover, which means the higher this likelihood the higher the probability of turnover. It is significant and positive $(\mathrm{t}-\mathrm{value}=10.00)$ which implies that as a second-incommand in financial reporting, CFOs are penalized. Year is negatively related with CFO turnover. For new firms, it is difficult to fire and replace executives. Moreover, there is not enough history to evaluate an executive performance.

Table 1.8 is similar to "Full Sample" in Table 1.7. I use firm and year fixed effect logit model. After controlling for time and firm characteristics, the prior year CEO turnover still significantly determines the CFO turnover. CEO turnover has a $t$-value of 25.16 and is significant at less than $1 \%$. Among other variables, prior year's return and the product of prior year's return with CEO turnover is significant. The prior year's return has a negative impact on the CFO turnover decision. However, when the CEO is replaced for the prior year's poor performance $\left(=\mathrm{CEOt}{ }^{*}\right.$ return $\left._{\mathrm{t}-1}\right)$, there is a severe consequence on the $\mathrm{CFO}$ turnover. For example, $t$-value for the prior year return is -2.28 , whereas $t$-value for the 
interaction term is 9.24 . The mean of the interaction term is negative $(=-0.90 \%)$ which justifies the fact of penalizing both CEOs and CFOs for the poor performance.

Table 1.9 includes the output from the hazard model. Originally used in cancer treatment, this model dynamically uses every piece of available information and updates the outcome variable. In my case, the model essentially uses all the years including nonCEO and non-CFO change years. Therefore, outcome from this model is more robust. In finance, Shumway (2001) first used it to forecast bankruptcy risk. Since then, many other researchers (Molina, 2002; Billett et al., 2011; Hazarika et al., 2012; Davidson et al., 2013) have used the hazard model. The output from this model is used to calculate the implied probability of CFO turnover conditioning on CEO turnover. I gradually build up the model. In "Model 1," I use last year's CEO turnover, the prior year's return, and the interaction term between them. In "Model 2," I add the natural log of sales. In "Model 3," I add the $\log$ of sales and F-score. The objective of the hazard model is to compute the very last column, probability rather than estimating any effect. Probability is calculated as the hazard ratio divided by (1+hazard ratio). In all three models, CEO turnover has at least $81 \%$ probability that the $\mathrm{CFO}$ will be replaced after a CEO replacement. CEO replacement due to a poor performance (represented by the interaction term) plays a significant role in CFO replacement (the minimum probability is $68 \%$ ). It is to be noted that CEO turnover includes all possible reasons for replacement such as non-alignment with the board, scandals, conflict of interests, and poor performance etc. Poor performance is one of the many reasons. Therefore, it is reasonable to have CEO turnover with a higher probability in the general case and CEO turnover $*$ Return $_{t-1}$ has a lower probability value. 
F-score or the probability of accounting earnings also plays a significant role in CFO replacement. As I mentioned earlier, a board is proactive in replacing the CEO or $\mathrm{CFO}$, if there is a trace that these executives are going to misstate earnings. Hazarika et al. (2012) show that it does not matter whether managers inflate or deflate earnings or if they receive any sanction by SEC or restate earnings. The board acts proactively and fires the executive(s) who might be involved in earnings misstatement. In my sample, I use restatement for the current year to calculate F-score, which based on Hazarika et al.'s (2012) findings, are correctly used. All the variables used in the three models are significant at $1 \%$ or lower (see $\mathrm{P}>\mathrm{Z}$ values in the column 5), except the natural log of sales in Model2, which is significant at the $5 \%$ level. The model fit statistics are reported in the bottom rows of each model. All three models are overall statistically significant (refer to LR chi $^{2}$, $\log$ likelihood and probability>chi ${ }^{2}$.

\subsection{Conclusion}

In this essay, I use a dynamic hazard model prescribed by Shumway (2001) which can produce much more accurate probabilistic inferences than a traditional (static) logit model. Moreover, in light of the growing importance of the role of CFO in the post-SOX era in corporate financial decision-making, I analyze his/her turnover relation with the CEOs. To my knowledge, there is no recent paper, especially after the SOX, which analyzes CEO-CFO relationship. It would be interesting if I could analyze both pre-andpost SOX scenarios. However, the data limitation hindered me from doing so.

Hazarika et al. (2012) show that both CEO and CFO have to leave the firm after an informal allegation of an earning misstatement is found by the firm's internal audit department and before the managers are found guilty when the firm announces an 
accounting restatement or sanctions by Securities and Exchange Commission (SEC) at a later period. Nowadays, corporate boards are more proactive than reactive as they used to be. The reason I use likelihood of restatement (denoted by F-score) as opposed to restatement per se is to capture the board's pro-activeness. Like Hazarika et al. (2012), I find consistent evidence of board pro-activism in replacing key executives due to poor performance and likelihood of earnings restatements. 
Figure 1.1 Spike of CFO Turnover following CEO Turnover

This figure shows the spike of CFO turnovers following the CEO turnover. In Full Sample, 5,186 CFOs were replaced, following 3,001 CEO replacements in the sample period of 2005-2014. In the case of both voluntary turnovers and involuntary turnovers, the increasing trend continued. The Voluntary Turnover includes resigned, whereas, Involuntary Turnover includes dismissed and employment ceased. In the opposite category, Remained, for Full Sample, 356 more CFOs remained in the position than CEOs. However, fewer CFO remained in the position following CEO involuntary and voluntary turnovers. The arrow indicates the spike of the CFO replacement following the CEO replacements.
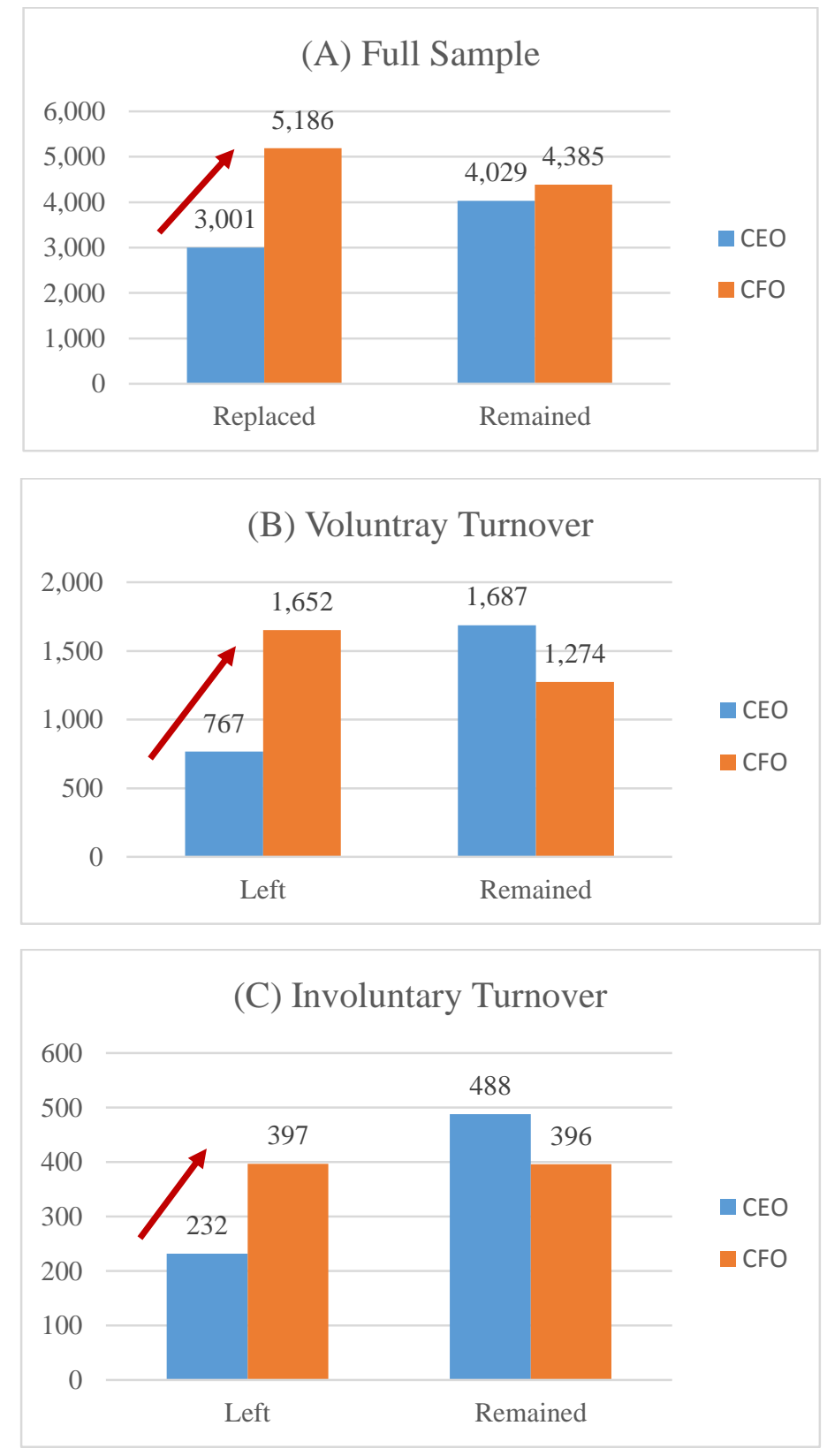


\section{Figure 1.2 CEO \& CFO Turnover}

This figure shows the distribution of CEO and CFO turnover in the sample period (20052014). The figure shows that CFO turnover follows the CEO turnover. Since 2009, the difference (in the figure, vertical distance) between CEO and CFO turnover shrunk. The financial crisis took a bigger toll on the CFO turnover than it did on CEO turnover. From 2008 to 2009, there is an abrupt drop in the CFO turnover. Overall, CEO turnover follows a smoother path than CFO turnover.

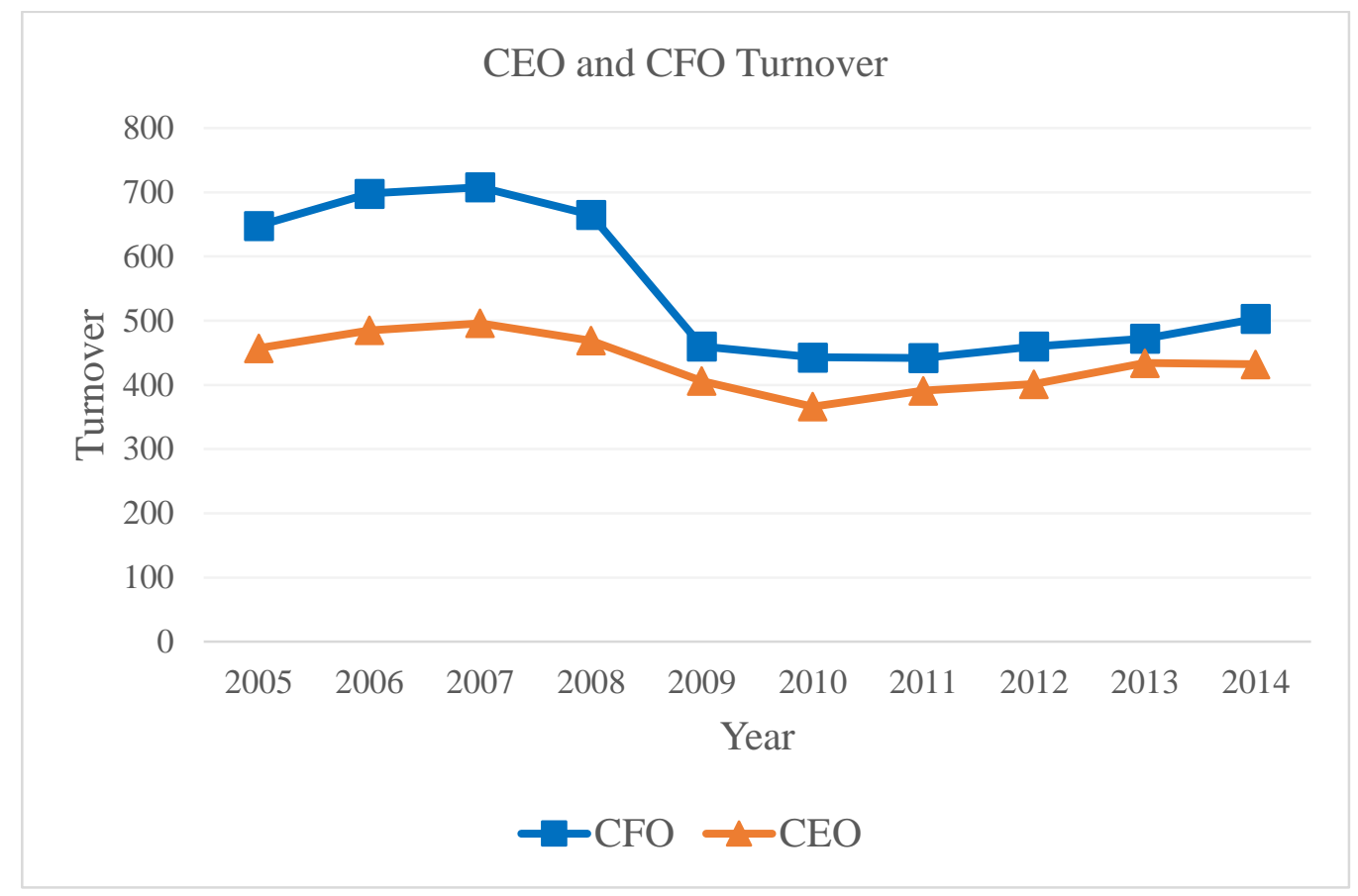


Table 1.1 Distribution of CEO and CFO Turnover

This table reports the turnover distribution for both CEOs and CFOs. Executive turnover happening for that year is represented by 1 and no turnover happening for that year is 0 . The number for both $\mathrm{CEO}$ and $\mathrm{CFO}$ turnover at the same time can be found by subtracting $\mathrm{CEO}=0$ from $\mathrm{CFO}=1$. For example, in 2007, there are 13 (=708-695) cases in which both the executives are replaced. Relatively, a high number of turnover occurred during 20052008. In all the years, CFO turnover is higher than CEO turnover.

\begin{tabular}{ccccccc}
\hline & \multicolumn{3}{c}{ CFO Turnover } & & \multicolumn{3}{c}{ CEO Turnover } \\
\hline Year & 0 & 1 & Total & 0 & 1 & Total \\
\hline 2005 & 453 & 648 & 1,101 & 644 & 457 & 1,101 \\
2006 & 475 & 698 & 1,173 & 688 & 485 & 1,173 \\
2007 & 483 & 708 & 1,191 & 695 & 496 & 1,191 \\
2008 & 463 & 665 & 1,128 & 659 & 469 & 1,128 \\
2009 & 398 & 460 & 858 & 452 & 406 & 858 \\
2010 & 363 & 443 & 806 & 440 & 366 & 806 \\
2011 & 384 & 442 & 826 & 435 & 391 & 826 \\
2012 & 397 & 460 & 857 & 456 & 401 & 857 \\
2013 & 429 & 472 & 901 & 467 & 434 & 901 \\
2014 & 429 & 503 & 932 & 500 & 432 & 932 \\
Total & 4,274 & 5,499 & 9,773 & 5,436 & 4,337 & 9,773 \\
\hline
\end{tabular}


Table 1.2 Distribution of CEO and CFO turnover category (2005-2014)

This table reports the turnover categories of CEOs and CFOs in the sample period, 20052014. The highest category is "appointed" which says the executive is appointed for the firm. "Resigned" is resignation. It includes both voluntary and involuntary resignation. Sometimes, the board does not want to fire CEOs or other key executives for personal reputation risk (Taylor 2010). "Dismissed" and "Employment Ceased" are considered as involuntary turnover. In my sample, I exclude "retired" and "deceased." Without these two categories, there are 9,063 total turnover events.

\begin{tabular}{lcccc}
\hline Turnover category & Frequency & Percent & $\begin{array}{c}\text { Cumulative } \\
\text { Frequency }\end{array}$ & $\begin{array}{c}\text { Cumulative } \\
\text { Percent }\end{array}$ \\
\hline Administrative Leave & 6 & 0.06 & 6 & 0.06 \\
Appointed & 5692 & 58.24 & 5,698 & 58.3 \\
Appointment Revoked/Not Accepted & 2 & 0.02 & 5,700 & 58.32 \\
Deceased & 23 & 0.24 & 5,723 & 58.56 \\
Declined Re-election & 1 & 0.01 & 5,724 & 58.57 \\
Dismissed & 150 & 1.53 & 5,874 & 60.1 \\
Employment Ceased & 494 & 5.05 & 6,368 & 65.16 \\
Nominated & 1 & 0.01 & 6,369 & 65.17 \\
Personal Leave & 30 & 0.31 & 6,399 & 65.48 \\
Re-elected & 16 & 0.16 & 6,415 & 65.64 \\
Resigned & 2650 & 27.12 & 9,065 & 92.76 \\
Retired & 687 & 7.03 & 9,752 & 99.79 \\
Retracted Resignation & 8 & 0.08 & 9,760 & 99.87 \\
Returned to Position & 13 & 0.13 & 9,773 & 100 \\
Turnover without "Deceased" and "Retirement" & & 9,063 & \\
\hline
\end{tabular}


Table 1.3 Descriptive Statistics (Full Sample)

This table reports the descriptive statistics of the variables used in the study. Current year's CFO return is $9.50 \%$ and the prior year's CEO turnover is $6.90 \%$. Return is defined as "firm's buy-and-hold stock return for the period ending at the start of the fiscal year during which the departure takes place less the value-weighted 2-digit compounded monthly industry return over this same period." (Fee and Hadlock 2004, p.14). The average return is positive, $15.00 \%$. The product of the prior year's return and this year's CEO turnover is negative $(=-0.90 \%)$. F-score implies the probability of a firm's earning restatement following Dechow et al. (2011). F-score=1 means the firm has the same unconditional expectation of accounting restatement. Unconditional expectation is calculated as the number of restated firms divided by the total firms (including restated firms) in the sample period. Values over 1.00 indicates the probability of restatement. On average, most of the firms have similar to unconditional expectation of restating earnings ( $F$ score is close to 1.00). The firms that restated their earnings were $8.80 \%$. Both change in ROA and change in employees are negative, which means during the sample period most of the firms had negative growth in earnings and also cut back on size (=number of employees). About $78 \%$ of the firms have future operating lease obligations and about $73 \%$ of the firms either issued debt or equity during the sample period (2005-2014).

\begin{tabular}{lccccc}
\hline \multicolumn{1}{c}{ Variable } & OBS & Mean & Std. Dev. & Min & Max \\
\hline CFO turnover & 56,729 & 0.091 & 0.288 & 0.000 & 1.000 \\
CEO turnover & 47,007 & 0.057 & 0.231 & 0.000 & 1.000 \\
Return ${ }_{\text {t } 1}$ & 48,698 & 0.121 & 1.052 & -0.949 & 7.249 \\
Ln of sales & 52,227 & 5.655 & 2.438 & -1.378 & 11.128 \\
CEO $^{*}$ Return $\mathrm{t}-1$ & 48,698 & -0.009 & 0.113 & -0.628 & 0.528 \\
F-score & 39,151 & 0.984 & 0.168 & 0.394 & 1.663 \\
Restatement & 42,378 & 0.088 & 0.284 & 0.000 & 1.000 \\
RSST accruals & 48,577 & 0.030 & 0.218 & -0.718 & 0.813 \\
$\Delta$ in receivables & 51,850 & 0.011 & 0.054 & -0.172 & 0.236 \\
$\Delta$ in inventories & 52,214 & 0.006 & 0.037 & -0.130 & 0.173 \\
Soft assets & 56,618 & 0.487 & 0.282 & 0.005 & 0.974 \\
$\Delta$ in cash sales & 47,428 & 0.119 & 0.828 & -3.190 & 5.266 \\
$\Delta$ in ROA & 48,791 & -0.005 & 0.155 & -0.605 & 0.619 \\
$\Delta$ in employees & 45,780 & -0.050 & 0.390 & -1.924 & 1.453 \\
Lease dummy & 56,729 & 0.779 & 0.415 & 0.000 & 1.000 \\
Issue & 56,729 & 0.731 & 0.443 & 0.000 & 1.000 \\
Year & 56,729 & 4.374 & 2.884 & 0.000 & 9.000 \\
\hline
\end{tabular}


Table 1.4 Descriptive Statistics (CEO-CFO Changed Years)

This table reports the descriptive statistics of the variables related with the firms that experienced CEO or CFO or both turnovers. The current year's CFO return is $54.20 \%$ and the prior year's CEO turnover is $42.70 \%$. Return is defined as “firm's buy-and-hold stock return for the period ending at the start of the fiscal year during which the departure takes place less the value-weighted 2-digit compounded monthly industry return over this same period." (Fee and Hadlock 2004, p.14). F-score implies the probability of a firm's earning restatement following Dechow et al. (2011). F-score=1 means the firm has the same unconditional expectation of accounting restatement. Unconditional expectation is calculated as the number of restated firms divided by the total firms (including restated firms) in the sample period. Values over 1.00 indicates the probability of restatement. On average, firms experienced CEO or CFO change have higher F-score than the overall. For example, $\mathrm{F}$ score for all firms is 0.98 versus 1.02 for only $\mathrm{CEO}$ or $\mathrm{CFO}$ change firms. $11.00 \%$ of the firms restated their earnings. Both change in ROA and change is employees are negative, which means during the sample period most of the firms had negative growth in earnings and also cut back on size (=number of employees). About $91 \%$ of the firms have future operating lease obligations and about $78 \%$ of the firms either issued debt or equity during the sample period (2005-2014).

\begin{tabular}{lccccc}
\hline Variable & OBS & Mean & Std. Dev. & Min & Max \\
\hline CFO turnover & 9,571 & 0.542 & 0.498 & 0.000 & 1.000 \\
CEO turnover & 7,030 & 0.427 & 0.495 & 0.000 & 1.000 \\
Return ${ }_{\text {- }}$ & 8,921 & 0.113 & 1.192 & -0.949 & 7.249 \\
Ln of sales & 9,281 & 5.656 & 2.415 & -1.378 & 11.128 \\
CEO $^{*}$ Return $\mathrm{t}-1$ & 8,921 & 0.022 & 0.653 & -0.925 & 4.820 \\
F-score & 7,613 & 1.016 & 0.145 & 0.394 & 1.641 \\
Restatement & 9,471 & 0.110 & 0.313 & 0.000 & 1.000 \\
RSST accruals & 8,390 & 0.000 & 0.228 & -0.718 & 0.813 \\
$\Delta$ in receivables & 9,108 & 0.007 & 0.057 & -0.172 & 0.236 \\
$\Delta$ in inventories & 9,065 & 0.003 & 0.040 & -0.130 & 0.173 \\
Soft assets & 9,549 & 0.540 & 0.260 & 0.005 & 0.974 \\
$\Delta$ in cash sales & 8,671 & 0.126 & 0.693 & -3.190 & 5.266 \\
$\Delta$ in ROA & 8,832 & -0.013 & 0.178 & -0.605 & 0.619 \\
$\Delta$ in employees & 8,822 & -0.039 & 0.393 & -1.924 & 1.453 \\
Lease dummy & 9,571 & 0.909 & 0.288 & 0.000 & 1.000 \\
Issue & 9,571 & 0.778 & 0.416 & 0.000 & 1.000 \\
Year & 9,571 & 4.183 & 2.918 & 0.000 & 9.000 \\
\hline
\end{tabular}


Table 1.5 Calculation of F-score following Dechow, Ge, Larson, and Sloan (2011)

The following table provides the maximum likelihood estimation from logit regression. The dependent variable is actual restatement which takes a value of 1 if the firm announce accounting restatement in any particular year and 0 otherwise. RSST accruals is calculated following Richardson, Sloan, Soliman, and Tuna (2005). Dechow et al. (2011) show only the following variables (refer Model \#2 in their paper) matter for determining the probability of accounting restatement. The model has the highest rate of correct classification (refer to p. 55-59) of restatement. Panel A reports the coefficient from the estimation. Panel B reports the information criteria. The log likelihood $(-2 \log \mathrm{L})$, Akaike's information criterion (AIC), and Schwarz criterion (SC) are reported in Panel B. AIC and -2 Log L are lower under "Intercept and Covariates" than under "Intercept Only," which implies the validity of the covariates used in the model estimation. Panel C provides a hypothesis test result if the global beta is 0 (=null hypothesis). The failure to reject the null hypothesis implies that the variables used are well picked to estimate the probability for the firm's accounting restatement.

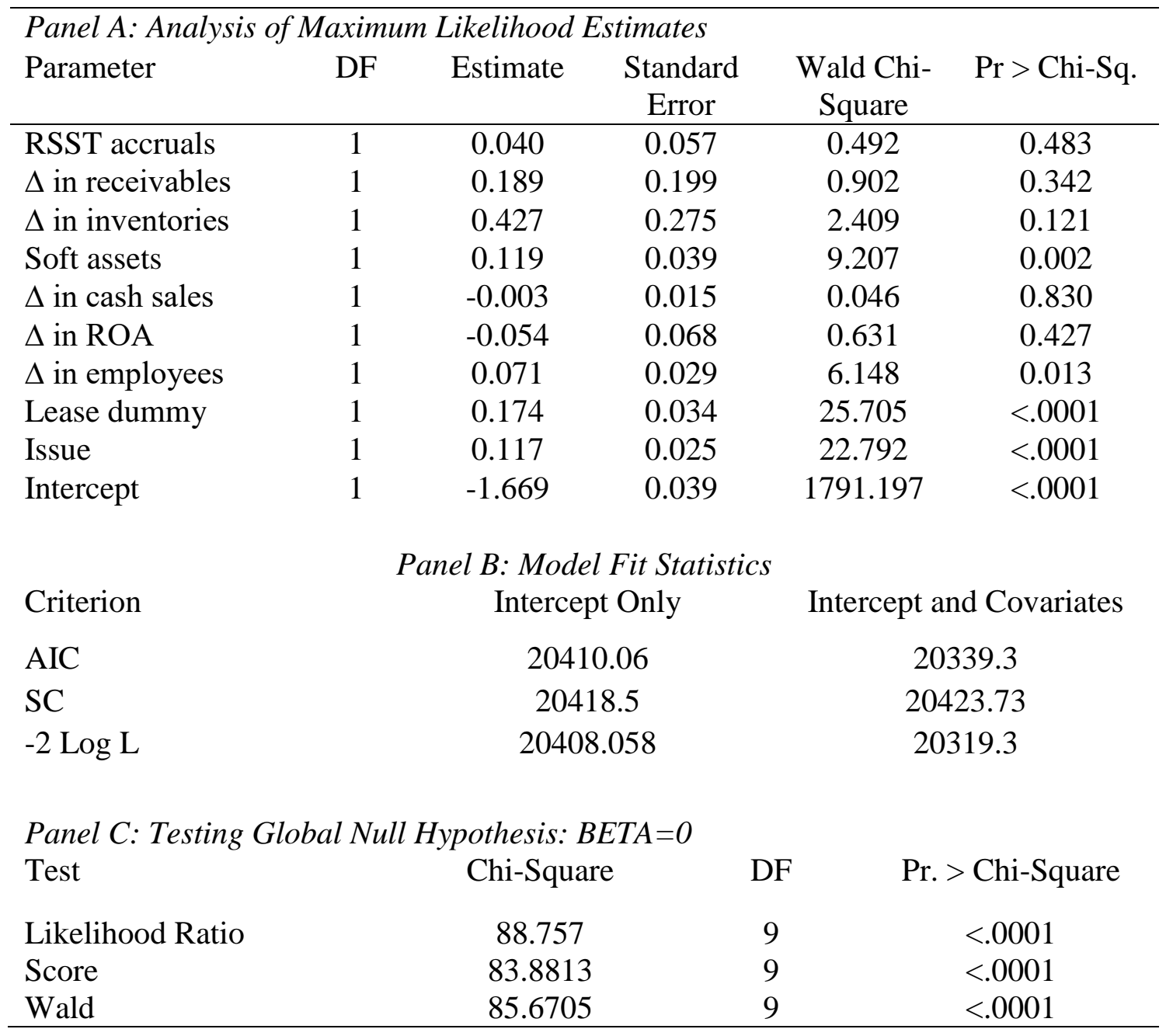


Table 1.6 Correlations

This table reports the correlations between variables. The correlation between CFO turnover and CEO turnover is 0.25 , which is significant at less than the $1 \%$ level. The positive correlation implies that following a CEO turnover there is a strong possibility for a subsequent CFO turnover. The prior year's poor performance can be a significant element to replace CEO and CFOs this year. For example, the interaction term, CEO ${ }_{t}^{*}$ Return $_{t-1}$ is significantly positively correlated with the current year's CFO turnover. Current year's sales are negatively correlated with the CFO turnover. The likelihood of earnings restatement designated by F-score is positively correlated with the CFO turnover, which means higher probability of accounting restatement will have higher CFO turnover. The italicized values are $p$-values for the respective correlation.

\begin{tabular}{|c|c|c|c|c|c|c|c|}
\hline & $\begin{array}{c}\mathrm{CFO} \\
\text { turnover }\end{array}$ & $\begin{array}{c}\text { CEO } \\
\text { turnovert-1 }\end{array}$ & Return $_{\mathrm{t}-1}$ & $\begin{array}{l}\text { Ln of } \\
\text { sales }\end{array}$ & $\begin{array}{c}\mathrm{CEO}_{\mathrm{t}} * \text { Ret } \\
\operatorname{urn}_{\mathrm{t}-1}\end{array}$ & F-score & Year \\
\hline CFO turnover & 1.000 & & & & & & \\
\hline \multirow[t]{2}{*}{ CEO turnover ${ }_{\mathrm{t}-1}$} & 0.246 & 1.000 & & & & & \\
\hline & $<.0001$ & & & & & & \\
\hline \multirow[t]{2}{*}{ Return $_{t-1}$} & 0.004 & -0.005 & 1.000 & & & & \\
\hline & 0.352 & 0.311 & & & & & \\
\hline \multirow[t]{2}{*}{ Ln of sales } & -0.004 & 0.018 & -0.068 & 1.000 & & & \\
\hline & 0.374 & 0.000 & $<.0001$ & & & & \\
\hline \multirow[t]{2}{*}{$\mathrm{CEO}_{\mathrm{t}} * \mathrm{Return}_{\mathrm{t}-1}$} & 0.026 & -0.129 & 0.210 & 0.035 & 1.000 & & \\
\hline & $<.0001$ & $<.0001$ & $<.0001$ & $<.0001$ & & & \\
\hline \multirow[t]{2}{*}{ F-score } & 0.067 & 0.042 & -0.005 & 0.097 & 0.000 & 1.000 & \\
\hline & $<.0001$ & $<.0001$ & 0.348 & $<.0001$ & 0.969 & & \\
\hline \multirow[t]{2}{*}{ Year } & -0.032 & 0.009 & -0.016 & 0.060 & 0.004 & -0.132 & 1.000 \\
\hline & $<.0001$ & 0.042 & 0.000 & $<.0001$ & 0.326 & $<.0001$ & \\
\hline
\end{tabular}


Table 1.7 Estimations from Logit Model

This table reports the results from logit model using all firm-years (both event and nonevent years). Column 1 lists all the independent variables. Column 2 has output for "Full Sample" category which includes all the turnover varieties (refer to Table 2) excluding deceased and retired. Column 3 and 4 list output for "Voluntary Turnover" and "Involuntary Turnover." Voluntary turnover includes "Resigned," whereas, involuntary turnover includes "Dismissed" and "Employment Ceased" categories. CEO turnover t $_{t-1}$ indicates the turnover of CEO in the previous year. It takes a value of 1 if there was a CEO turnover in the previous year and 0 otherwise. Return $t_{-1}$ is defined as the "firm's buy-andhold stock return for the period ending at the start of the fiscal year during which the departure takes place less the value-weighted 2-digit compounded monthly industry return over this same period." (Fee and Hadlock 2004, p.14) Ln of sales is the natural log of sales for the current year. $C E O_{t} *$ Return $_{t-1}$ is the product of the last year's return (as defined before) and this year's CEO turnover. F-score is the probability of accounting restatement and is calculated following Dechow et al. (2011) [refer to Table 1.5]. Year is a time variable taking the value from 0 (start of the sample period, 2005) to 10 (end of the sample period, 2014).

\begin{tabular}{|c|c|c|c|}
\hline Dependent variable: CFO turnover & Full Sample & $\begin{array}{l}\text { Voluntary } \\
\text { Turnover }\end{array}$ & $\begin{array}{c}\text { Involuntary } \\
\text { Turnover }\end{array}$ \\
\hline CEO turnover ${ }_{t-1}$ & $\begin{array}{c}1.913 * * * \\
(37.97)\end{array}$ & $\begin{array}{c}-0.457 * * * \\
(-4.31)\end{array}$ & $\begin{array}{l}0.010 \\
(0.05)\end{array}$ \\
\hline Return $_{\mathrm{t}-1}$ & $\begin{array}{c}-0.056^{* * *} \\
(-2.60)\end{array}$ & $\begin{array}{c}-0.308 * * * \\
(-5.27)\end{array}$ & $\begin{array}{l}-0.058 \\
(-0.62)\end{array}$ \\
\hline Ln of sales & $\begin{array}{c}-0.050 * * * \\
(-6.07)\end{array}$ & $\begin{array}{c}-0.085 * * * \\
(-3.57)\end{array}$ & $\begin{array}{l}-0.048 \\
(-1.18)\end{array}$ \\
\hline $\mathrm{CEO}_{\mathrm{t}} *$ Return $_{\mathrm{t}-1}$ & $\begin{array}{c}1.260 * * * \\
(8.98)\end{array}$ & $\begin{array}{c}3.204 * * * \\
(13.67)\end{array}$ & $\begin{array}{c}1.725^{* * *} \\
(4.57)\end{array}$ \\
\hline F-score & $\begin{array}{c}1.217 * * * \\
(10.00)\end{array}$ & $\begin{array}{l}0.168 \\
(0.48)\end{array}$ & $\begin{array}{l}0.970 \\
(1.46)\end{array}$ \\
\hline Year & $\begin{array}{c}-0.039 * * * \\
(-5.34)\end{array}$ & $\begin{array}{c}-0.031 * \\
(-1.67)\end{array}$ & $\begin{array}{l}0.012 \\
(0.33)\end{array}$ \\
\hline Constant & $\begin{array}{c}-3.080 * * * \\
(-22.99)\end{array}$ & $\begin{array}{c}1.066^{* * * *} \\
(2.95)\end{array}$ & $\begin{array}{l}-0.649 \\
(-0.95)\end{array}$ \\
\hline R-squared & 0.066 & 0.095 & 0.035 \\
\hline NOBS & 32,464 & 1,917 & 574 \\
\hline
\end{tabular}


Table 1.8 Estimation from Fixed Effect Logit Model

This table reports the results from the firm and time fixed effect model using all firm-year data. My variable of interest, CEO turnover $_{t-1}$ significantly (at less than $1 \%$ ) positively affects the CFO turnover: negative performance increases the chance of CFO replacement, whereas positive performance increases the probability of remaining in the position. The $t$ value is 11.42 . The past year's return significantly affects CFO turnover. The coefficient for $C E O_{t} *$ Return $_{t-1}$ is significant and positive, which means that if the CEO is replaced due to the prior year's (negative) performance then the effect of the CFO turnover is positive.

\begin{tabular}{|c|c|c|c|c|c|c|}
\hline $\begin{array}{c}\text { Dep. Variable: } C F O \\
\text { turnover }\end{array}$ & Coef. & Std. Err. & $\mathrm{t}$ & $P>t$ & \multicolumn{2}{|c|}{$\begin{array}{c}\text { [95\% Conf. } \\
\text { Interval] }\end{array}$} \\
\hline CEO turnover ${ }_{t-1}$ & 1.617 & 0.064 & 25.16 & 0.000 & 1.491 & 1.743 \\
\hline Return $_{\mathrm{t}-1}$ & -0.055 & 0.024 & -2.28 & 0.023 & -0.102 & -0.008 \\
\hline Ln of sales & -0.042 & 0.046 & -0.92 & 0.358 & -0.132 & 0.048 \\
\hline $\mathrm{CEO}_{\mathrm{t}} * \operatorname{Return}_{\mathrm{t}-1}$ & 1.526 & 0.165 & 9.24 & 0.000 & 1.202 & 1.850 \\
\hline F-score & -0.105 & 0.227 & -0.46 & 0.645 & -0.550 & 0.341 \\
\hline Firm fixed effect? & Yes & & & & & \\
\hline Year fixed effect? & Yes & & & & & \\
\hline Log likelihood & $-4,602.524$ & & & & & \\
\hline LR Chi2 (13) & 764.790 & & & & & \\
\hline Prob> Chi2 & 0.000 & & & & & \\
\hline
\end{tabular}


Table 1.9 Estimation from Dynamic Hazard Model

This table provides the estimation results from Hazard Model using "Full Sample" and all year data. Model-1 is the base model. Additional variables are added in Model 2 and Model 3. Ln of sales and ln of sales with F-score are added to Model 2 and Model 3, respectively. The second column reports the hazard ratio (HR) from maximum likelihood estimation. The last column, probability is calculated by dividing HR/(1+HR). This column provides the probability (effect) of the independent variables on the dependent variable. The probability provides the likelihood of hazard (in this case, turnover) conditional on the survival up until the replacement. In all three models, the prior year's CEO turnover is a significant event to replace the current year's CFO. In Model 3, in the presence of restatement probability and $\mathrm{ln}$ of sales, the most three significant variables are: prior year CEO turnover ( $=82 \%$ probability on CFO turnover), the CEO turnover for the prior year's poor performance $\left(\mathrm{CEO}_{\mathrm{t}} * \mathrm{Return}_{\mathrm{t}-1}=68 \%\right.$ probability on $\mathrm{CFO}$ turnover $)$, and $\mathrm{F}$-score $(=79 \%$ probability on $\mathrm{CFO}$ turnover).

\begin{tabular}{|c|c|c|c|c|c|c|c|}
\hline \multicolumn{8}{|c|}{ Model \#1 } \\
\hline Covariates & $\begin{array}{c}\text { Hazard } \\
\text { Ratio }\end{array}$ & Std. Err. & $\mathrm{Z}$ & $\mathrm{P}>\mathrm{Z}$ & \multicolumn{2}{|c|}{$\begin{array}{c}\text { [95\% Conf. } \\
\text { Interval] }\end{array}$} & Probability \\
\hline CEO turnover ${ }_{\mathrm{t}-1}$ & 5.022 & 0.183 & 44.210 & 0.000 & 4.675 & 5.394 & $83.39 \%$ \\
\hline Return $_{\mathrm{t}-1}$ & 0.914 & 0.016 & -5.280 & 0.000 & 0.883 & 0.945 & $47.74 \%$ \\
\hline $\mathrm{CEO}_{\mathrm{t}} *$ Return $_{\mathrm{t}-1}$ & 2.116 & 0.218 & 7.260 & 0.000 & 1.728 & 2.590 & $67.90 \%$ \\
\hline Year & 0.000 & 0.000 & -76.900 & 0.000 & 0.000 & 0.000 & $0.00 \%$ \\
\hline Number of obs & & 42,544 & & & & & \\
\hline LR $\operatorname{chi}^{2}(4)$ & & 65,449 & & & & & \\
\hline Log likelihood & & 44,342 & & & & & \\
\hline Prob > chi 2 & & 0.000 & & & & & \\
\hline \multicolumn{8}{|c|}{ Model \#2 } \\
\hline Covariates & $\begin{array}{c}\text { Hazard } \\
\text { Ratio }\end{array}$ & Std. Err. & $\mathrm{Z}$ & $\mathrm{P}>\mathrm{Z}$ & \multicolumn{2}{|c|}{$\begin{array}{c}\text { [95\% Conf. } \\
\text { Interval] }\end{array}$} & Probability \\
\hline CEO turnover $r_{t-1}$ & 4.772 & 0.177 & 42.220 & 0.000 & 4.438 & 5.131 & $82.68 \%$ \\
\hline Return $_{\mathrm{t}-1}$ & 0.907 & 0.016 & -5.530 & 0.000 & 0.876 & 0.939 & $47.55 \%$ \\
\hline Ln of sales & 0.984 & 0.006 & -2.530 & 0.011 & 0.971 & 0.996 & $49.59 \%$ \\
\hline $\mathrm{CEO}_{\mathrm{t}} *$ Return $_{\mathrm{t}-1}$ & 2.137 & 0.223 & 7.260 & 0.000 & 1.741 & 2.623 & $68.12 \%$ \\
\hline Year & 0.000 & 0.000 & -77.710 & 0.000 & 0.000 & 0.000 & $0.00 \%$ \\
\hline Number of obs & & 39,594 & & & & & \\
\hline $\operatorname{LR} \operatorname{chi}^{2}(5)$ & & 63,737 & & & & & \\
\hline Log likelihood & & 43,456 & & & & & \\
\hline Prob $>\mathrm{chi}^{2}$ & & 0.000 & & & & & \\
\hline
\end{tabular}

Model \#3

$\begin{array}{cccccc}\text { Covariates } & \begin{array}{c}\text { Hazard } \\ \text { Ratio }\end{array} & \text { Std. Err. } & \mathrm{z} & \mathrm{P}>\mathrm{z} & \begin{array}{c}\text { [95\% Conf. } \\ \text { Interval] }\end{array}\end{array}$ Probability 


\begin{tabular}{|c|c|c|c|c|c|c|c|}
\hline CEO turnover ${ }_{t-1}$ & 4.513 & 0.182 & 37.390 & 0.000 & 4.170 & 4.884 & $81.86 \%$ \\
\hline Return $_{\mathrm{t}-1}$ & 0.891 & 0.019 & -5.540 & 0.000 & 0.855 & 0.928 & $47.12 \%$ \\
\hline Ln of sales & 0.958 & 0.007 & -5.610 & 0.000 & 0.944 & 0.973 & $48.93 \%$ \\
\hline $\mathrm{CEO}_{\mathrm{t}} *$ Return $_{\mathrm{t}-1}$ & 2.231 & 0.254 & 7.060 & 0.000 & 1.785 & 2.788 & $69.05 \%$ \\
\hline F-score & 3.854 & 0.440 & 11.810 & 0.000 & 3.081 & 4.820 & $79.40 \%$ \\
\hline Year & 0.000 & 0.000 & -70.470 & 0.000 & 0.000 & 0.000 & $0.00 \%$ \\
\hline Number of obs & & 32,464 & & & & & \\
\hline $\operatorname{LR} \operatorname{chi}^{2}(6)$ & & 53,900 & & & & & \\
\hline Log likelihood & & 36,808 & & & & & \\
\hline Prob $>$ chi $^{2}$ & & 0.000 & & & & & \\
\hline
\end{tabular}


CHAPTER 2: DOES THE CFO APPOINTMENT TYPE AFFECT THE FIRM'S DEBT-

\section{EQUITY CHOICE?}

\subsection{Introduction}

The choice a firm makes between debt and equity is always puzzling. In the seminal paper on firm's capital structure, Myers (1984) notes, "How do firms choose their capital structures? Again, the answer is we don't know (p. 575)." He shows that firms aim for an optimal capital structure based on the benefits and costs of debt and firms try to work on any deviation from that optimal mix of debt and equity. Myers and Majluf (1984) show that firms follow a pecking order, i.e., prefer internal to external financing and debt to equity financing. In a recent paper, Fama and French (2005) show that firms no longer follow pecking order and the majority of firms issue equity. In addition, Hovakimian et al. (2001) show that firms consistently try to reach the optimal target debt ratio. However, due to the dynamic nature of a firm's profitability and stock market activism, the target debt ratio changes over time. Firms have to consistently engage in adjusting capital structure activities, i.e., issue debt or equity, repurchase stocks and retire debt, to achieve an ever changing target (optimal) capital structure.

The search for CFOs from the external labor market is costly and time consuming. Firms want to avoid the searching costs for a CFO if they can find a capable individual inside the organization. A recent study sponsored by Chicago Booth Executive Education, University of Chicago, reports that four out of five times, firms promote internals as CEOs $^{12}$. Cremers and Grinstein (2008) find that $68 \%$ of the CEOs were former employees

\footnotetext{
${ }^{12}$ It is a comprehensive study on the CEOs titled "CEO Succession 2000-2009: A Decade of Convergence and Compression." A short description about the report, "Convergence and compression - these are the
} 
of the same firm and $86 \%$ belonged to the same industry. For some reason, firms have to go for external hires. Compared to internally promoted CFOs, external CFOs have to take time to learn the culture of the organization, its financing, investment, and other policies.

Inversely, internal hires have an edge over the external hires in terms of understanding the firm's policies, maintaining the commitment to the investors, and furnishing timely information to the investors. The Chicago Booth (2010) study finds Insider candidates are naturally more knowledgeable about the company and the challenges and opportunities it confronts. They also tend to perform better and last longer, according to our research. Of the CEOs leaving office, insiders have produced superior regionally market-adjusted shareholder returns in seven of the last 10 years, averaging 2.5 percent; outsider-generated returns, in comparison, have averaged 1.8 percent (p. 6).

Therefore, in terms of CFO hiring, unless it is really expected by the market to hire a new $\mathrm{CFO}$ from the external labor market, firms go for promoting incumbents as $\mathrm{CFOs}{ }^{13}$.

Nevertheless, hiring from an external source is more expensive than promoting inside the organization. Murphy and Zabojnik (2003, 2004) document that external hires cost $15.30 \%$ more than internally promoted $\mathrm{CEOs}^{14}$. The cost of hiring from the external

\footnotetext{
macro themes that emerge from our analysis of 10 consecutive years' worth of detailed data on CEO succession among the world's top 2,500 public companies. This rich database comprises 3,719 CEO turnover events globally." For the full report, please refer to http://www.strategy-business.com/article/10208.

${ }^{13}$ Situations in which the market expects an external hire are if the firms receive an adverse SOX 404 opinion, if the firm's current CFO consistently fails to meet analysts' expectations or if the firm has been doing poorly for the last few years (Mian, 2001).

${ }^{14}$ As the authors document this premium has increased over time: $6.50 \%$ in $1970 \mathrm{~s}, 17.20 \%$ in $1980 \mathrm{~s}$, and $21.60 \%$ in 1990 s.
} 
labor market has increased over time. Taylor (2010) shows that replacing a CEO (who was fired) can cost at least $\$ 200$ million to shareholders, and shareholder value is increased by $3 \%$ if these (perceived) costs can be eliminated. The perceived costs associated with a new hire are due to entrenchment (or poor governance). Extant literature ${ }^{15}$ shows that when there is a forced turnover, firms usually hire from the external labor market. Instead, promoting someone from inside the organization can save the turnover costs.

Myers and Majluf (1984) show that due to adverse selection (managers having better information than general investors) managers avoid issuing equity and forgo profitable project opportunities. The less adverse selection or information asymmetry motivates managers to issue equity rather than debt. Dittmar and Thakor (2007) show that managers issue equity when investors' views and managers' views are aligned in terms of project payoffs. Firms can reduce information asymmetry either by external certification, such as employing high quality auditors, or by internal mechanisms such as policies to share timely information with the investors. The ultimate responsibility lies with the management of firms on how much information they want to share with investors. Both the management leadership choice and the policies of the firm affect the extent of information asymmetry and ultimately affect the financing decision of the firm.

An internal CFO, assuming that $\mathrm{s} / \mathrm{he}$ has been with the firm at least for a year, knows the firm's reporting policies better than an external CFO. Chung et al. (2010) establish a relationship between a firm's governance and information asymmetry. They show that good governed firms have less information asymmetry whereas poorly governed

\footnotetext{
${ }^{15}$ Parrino (1997) finds that the real costs of firing a CEO is lower when firms can find a replacement in similar (homogeneous) industry. Also, Mian (2001) finds that investors expect an external hire when firms had few years of negative performance.
} 
firms have more information asymmetry. They note “... poor governance gives rise to greater information asymmetry between the insiders (e.g., managers/controlling shareholders) and outside owners (p. 279)." If an internally promoted CFO is shown to improve a firm's governance or equivalently reduce information asymmetry, then the firm will have greater incentive to issue equity. The relation between issuing equity and firm asymmetry is negative. In the absence of information asymmetry, firms no longer refuse to issue stock, and therefore, do not pass up valuable investment opportunities (Myers and Majluf, 1984).

The chief financial officer (CFO), being the overseer of the firm's financial disclosure, can significantly contribute to reducing the information gap between firm and investors. Among other managers of the firm, CFOs carry an important role in determining corporate financial decisions after the chief executive officer (CEO). Geiger and North (2006) find that discretionary accruals significantly decreased surrounding new CFO appointments, and their finding is not driven by the concurrent CEO appointments. Thus, it is reasonable to say that CFOs do have their independent opinions in financial decision making. In addition, the CFO's background ${ }^{16}$ matters in corporate investment and financing decisions. Firms can hire CFOs from two sources: a) they can promote someone qualified to become the $\mathrm{CFO}$, and b) they can hire from the external labor market. The most likely incumbents for CFOs are treasurers, controllers, and principal accounting officers. Firms promote incumbents when there are no expectations from the stock market

\footnotetext{
${ }^{16}$ Brettel et al. (2008) find that firms with overconfident CFOs have higher debt in their capital structure. Ben-David, Graham, and Harvey (2007) show that overconfident CFOs use a lower discount rate to evaluate their cash flows, use more debt, invest more, pay lower dividends, and repurchase more shares.
} 
to hire from the external labor market ${ }^{17}$. On the contrary, if the firms are meeting the expectations of investors by providing adequate and timely information and lessening the information asymmetry, firms tend to promote an incumbent as the CFO. The internal managers play a significant role in reducing information asymmetry, as noted by Myers and Majluf (1984), “They [managers] have an insider's view of their organization and what it can and cannot do. This organizational knowledge is part of managers' human capital; they acquire it as they work, by conscious effort as well as by trial and error (p. 196).”

The internal CFOs have stronger incentives to approach the investors for financing within a year to take advantage of the news of his/her promotion to the CFO. As internal CFOs' interests are better aligned with that of the investors, they would approach equity financing rather than debt financing. Equity financing is better when firms have a clear idea of the expected payoffs of the potential projects. Shareholders are the owners of the firms; they do not pose a threat of bankruptcy like debt holders do in case of the firm's inability to pay the reward for capital provided. Debt holders need detailed information about potential projects before making the issue decision. Sharing detailed information of potential profitable projects with the third party is strategically disadvantageous to the firms. When internal CFOs with a good understanding of the project payoffs approach the owner-investors of the firm, s/he can expect to receive the funds without the fear of leaking the information to the firm's competitors. Internal CFOs will be more inclined toward issuing equity than issuing debt. In addition, contrary to "pecking order ${ }^{18 "}$ theory, firms

\footnotetext{
${ }^{17}$ Mian (2001) shows that when firms do not perform well for the last few years (he tested for the last five years), the market expectation is that there will be a CFO hire from the external labor market.

${ }^{18}$ Firms finance investments from retained earnings, then riskless debt, followed by risky debt and as the last resort, go for equity issue such as "financial duress" (Myers and Majluf, 1984; Dittmar and Thakor ,2007)
} 
frequently issue equity. Fama and French (2005) notes $86 \%$ of their sample firms issue equity of some form during their sample period, 1993-2003.

I find that internally promoted CFOs significantly issue equity relative to an external hired CFO. When an incumbent is promoted as the CFO, firms have a $20 \%$ higher probability of issuing equity than in the case of hiring an external CFO. I also find that younger, growth and lowly levered firms promote incumbents as CFOs. For example, the average age of the firms promoting internals as CFOs is 12.72 years, whereas for firms hiring external CFOs, it is 17.43 years (a statistically significant difference). Market to book ratio for internal hire firms is 2.30 and for external hire 1.97 (a statistically significant difference); the mean leverage ratio for internal hire firms is 0.33 , and for external hire, it is 0.38 (again, a statistically significant difference).

Potential endogeneity may be present because there are some unobserved firm characteristics or random shocks that may affect both firm's choice of issuing equity and appointment of an internal as the CFO. I control for potential endogeneity by using instrumental variable (IV) approach. In addition to the most common IV estimator, 2SLS (two stage least squares) model, I also use maximum likelihood estimation and generalized method of moments (GMM) estimators. Following a similar type of instrument by Balsam et al. (2016), I used industry CFO ratio as instrument and find that internal CFO appointment significantly affects the firm equity issue. Z-value for INTERNAL is 3.10 $(\mathrm{P}<|\mathrm{z}|=0.002)$. I also tested for the validity or the strength of the chosen instrument, which resulted in a partial F-value of 45.66 in the first-stage regression, ensuring that the chosen instrument is valid and strong. 
I employ all the known factors found in the earlier research that affect capital structure decision of a firm. After controlling all these debt-equity choice variables, my findings hold. I also find some interesting phenomena of internal CFOs, which also help to explain a firm's equity choice after the CFO turnover. Some of the findings are worth mentioning. First, I find younger and smaller firms promote incumbents as the CFO. Frank and Goyal (2009) notes that since 1990, more small firms go for equity financing. Second, I find profitable firms employ internal CFOs and firms with negative ROA employ external CFOs. This is consistent with Mian (2001) who finds a strong association between a firm's negative operating performances and external CFO appointments. Third, firms with high stock returns promote internals as CFOs. Hovakimian et al. (2004) show that firms with high stock returns have higher probability of issuing equity.

\subsection{Literature Review and Development of Hypotheses}

Information asymmetry arises because of the information gap between management and investors. Information asymmetry is a market friction, which can subdue the potential growth of the firms. If the market was frictionless, meaning that investors would have access to private or privileged information, then managers would invest the optimal amount, i.e., no over or under investment. If investors think that managers are trying to sell overpriced securities, then they will buy less or they will ask for a higher return (thus increasing cost of capital) in the form of discounts. In the earlier finance literature, equity was shown as the last resort of financing for firms, and firms only issue equity in extreme times or financial duress (Myers and Majluf, 1984). However, Fama and French (2005) document that $86 \%$ of their sample firms issue equity of some form and firms neither issue equity at the time of financial duress nor repurchase equity when outside 
demand is lower. They, as such, conclude that the pecking order of capital structure is no longer alive.

Frank and Goyal (2009) test the pecking order theory in respect to American firms and find that external financing is much more significant than recognized in the literature, and equity is a significant component of external financing. I hypothesize that a CFO who is recently promoted within the firm with an expectation to add value to the company's operation would be able to minimize the information gap between two parties and could facilitate the external financing by equity. The appointment of an able CFO who has worked for the firm, knows the firm's operation in detail, has a good tie with the investors, and would take advantage of going for equity financing. Since s/he knows that $\mathrm{s} / \mathrm{he}$ is implementing the investment or growth plans that are well thought by the current board, his or her only job is to make sure that information conveyed to investors regarding the project payoffs are transparent, timely, and complete. When companies have less information asymmetry between managers and investors, they go for equity (opposite to what pecking order theory ${ }^{19}$ predicts). Therefore, I posit:

Hypothesis: Firms that have recently promoted an incumbent to a CFO are more likely to issue equity as opposed to debt than firms that have hired a CFO from external labor markets.

\subsection{Data and Sample Selection}

I collect the firm-level data from COMPUSTAT. Return data and number of analysts are taken from CRSP (Center for Research in Security Prices) and IBES

\footnotetext{
${ }^{19}$ Myers (1984) first points out that due to adverse selection firms prefer internal finance to external finance and if firms have to go for external finance they prefer debt to equity because equity issue is cumbersome.
} 
(Institutional Brokers' Estimate System), respectively. Companies that are not covered by IBES are assumed not to be followed by any analyst (Chang et al. 2009). Following extant literature (see Ferris et al. 2013), I define external and internal CFO as follows: CFOs who are with the company at least for one year are labeled as INTERNAL and CFOs that are newly hired and with the company for less than a year are defined as external. I take all the firms in the EXECOMP database over the period of 1992-2014. I measure the tenure before becoming the $\mathrm{CFO}$ as the difference between the year at which s/he is hired by the firm and the year s/he is appointed as the CFO. For example, if a CFO is hired in 2007 (in the database shows up as CFO) and the year in which his or her name shows up for the first time is 2005 , then s/he will be an internal CFO. The difference in this case is 2 years. However, the same CFO's name shows up for the first time in 2007 and thus, the difference is 0 would be defined as external. In defining internal CFOs, when the year difference (tenure) is 1 , then the case might be confounding. For example, if an employee is hired right before the reporting date, then right after the reporting date, s/he is promoted as the $\mathrm{CFO}$ and another employee in another firm is hired as a non-CFO employee and promoted to CFO right before the next year reporting. In both cases, they will be labeled as "internal." However, the CFO in the first example is not really a true INTERNAL. As there is no available data source for me to verify this type of scenarios without specific appointment date, I excluded internal CFOs that have a year difference of one. By including all the internals that have a year difference of two or more, I make sure that a CFO who has promoted internally has served the company at least one year. Please refer to a hypothetical 
scenario presented in Figure 1. My sample covers 1994-2014 ${ }^{20}$. I have included firm-years in which there is a CFO change and firms issued either debt or equity (according the definition given earlier). To exclude the effect of concurrent CEO turnover on equity issue, I dropped all the firm-years in which there were both CEO and CFO turnovers occurred. Finally, I have 1,045 firm-years, which meet all my sample selection criteria. The number of observations across models are different due to: a) using more variables into some model than others, and b) not all variables having the data for the same years. I mention the number of observations (NOBS) used in the models in the result tables.

\subsection{Methodology}

\subsubsection{Main Model}

Taylor (2010) estimates CEO firings using the structural equation model. He shows that CEOs are rarely fired by the board because of the personal costs associated with it. The CEO firing puts the personal reputation of the board members at risk to be appointed for other boards. In order to minimize the risk, the board of a weakly governed firm would not fire a bad CEO. He shows that reduction of entrenchment equivalently improving governance mechanism can significantly increase the returns to shareholders. In the same line of thinking, I conjecture that an internal CFO improves a firm's overall governance by reducing entrenchment. However, it is plausible that good governed firms appoint an internal as CFO. I use Bebchuk et al. (2008) e-index which is a parsimonious form of governance index developed by Gompers, Ishii and Metric (2003) and shows that only six

\footnotetext{
${ }^{20}$ 1992-1993 are not considered because of INTERNAL definition. Previous 2-year is needed to define INTERNAL.
} 
provisions (out of 24 IRRC provisions ${ }^{21}$ ) matters for the firm value. Four of the six provisions deal directly with shareholder rights: staggered board, limits to shareholder amendments of the by-laws, supermajority requirements for mergers, and supermajority requirements for charter amendments. These are the primary powers shareholders have (Bebchuk et al. 2008). If a firm practices good governance, then the appointment of CFOs will enhance the value of the shareholders by reducing any form of entrenchment. I proxy a firm's governance by Bebchuk et al.'s e-index (or entrenchment index) which potentially should have a strong negative correlation with the internal appointment. The lower entrenchment means better governance mechanism of the firms which means shareholders have more control over the management. The reason internal appointments are a result of better governance is that the firm knew the promoted CFO for a while. If the incumbent was not the optimal choice, then the board would not promote him/her as the CFO, but rather the firm would look for an external hire. Taylor (2010) states, "At each point in time, the board observes the two signals, assesses the CEO's ability, and then decides optimally whether to replace him or her with a new CEO of uncertain ability (p. 2052)." The same assertion goes with the $\mathrm{CFO}$, if firms find an eligible candidate inside the firm who the board knows and has a greater confidence in his or her abilities, then they will go for internal hire. An internal CFO who has a better understanding of the company and its stakeholders will improve the governance of the hiring firm. Because the firm has maintained a good rapport with the shareholders and newly appointed CFO is carrying out the board's investment plan, there is no need to go for debt financing which inherently

${ }^{21}$ The Investor Responsibility Research Center Institute, please refer to http://irrcinstitute.org/ 
increases a firm's bankruptcy risk and often comes with stringent covenants or conditions. The following simple mathematical framework can be used to assess the effect of an internal CFO on governance and a firm's choice of equity ${ }^{22}$ :

$$
\text { Equity }=\beta_{0}+\beta_{1} \text { Governance }+\beta_{2} \text { INTERNAL }
$$

Assuming an internal CFO improves governance,

$$
\text { Governance }=\gamma_{0}+\gamma_{1} \text { INTERNAL }
$$

Incorporating equation (2) into (1),

$$
\text { Equity }=\beta_{0}+\beta_{1}\left(\gamma_{0}+\gamma_{1} \text { Internal }\right)+\beta_{2} \text { INTERNAL }
$$

Or,

$$
\text { Equity }=\left(\beta_{0}+\beta_{1} \gamma_{0}\right)+\left(\beta_{1} \gamma_{1}+\beta_{2}\right) \operatorname{INTERNAL}
$$

Proxy for a firm's governance, e-index, and internal CFO (INTERNAL) cannot be present in the same equation, because an internal CFO improves governance (or governance is a function of an internal CFO) and putting them together on the right hand side would create a multicollinearity issue. In equation (3), $\beta_{2}$ is the direct effect of an internal on a firm's equity choice, and $\beta_{1} \gamma_{1}$ captures the indirect effect ${ }^{23}$. In addition to OLS, I run the firm fixed effect in equation (3). The year fixed effect cannot be added because I only keep the firm-year in which a CFO turnover occurred and issue condition (>5\% of assets) is met.

\footnotetext{
${ }^{22}$ I intentionally keep out error terms to keep things simpler.

${ }^{23}$ An example using a similar type of specification can be found:

https://www.kellogg.northwestern.edu/faculty/dranove/htm/dranove/coursepages/Mgmt\%20469/choosing\% 20variables.pdf
} 
The prime responsibility of the CFO is to oversee firm's financial reporting mechanism. The earlier argument of CFO impacting firm overall governance may seem overstated because typically governance mechanism can be impacted by the board and to some extent by the CEO. However, the CFO can impact governance by adopting fair and timely disclosure. I use the following regression incorporating Bid-Ask Spread as a conduit to improve firm governance by a CFO. Ideally, the CFO will have a negative impact of information asymmetry (represented by Bid-Ask Spread) and positive impact on firm equity issue. I use the following model incorporating information asymmetry:

$$
\text { Equity }=\beta_{0}+\beta_{1} I N T E R N A L+\beta_{2} \operatorname{InfAsym}+\beta_{3} I N T E R N A L * \operatorname{InfAsym}
$$

In the multiple regression framework, I use the following specification:

$$
\begin{aligned}
& \text { Equity }_{i, t}= \\
& \text { INTERNAL }_{i, t}+\text { Tangibility }_{i, t}+\text { Levratio }_{i, t}+\text { ROA }_{i, t}+\text { Sharetrunover }_{i, t}
\end{aligned}
$$

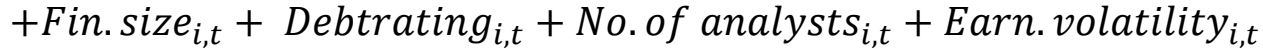

$$
\begin{aligned}
& + \text { Returnvolatility }_{i, t}+\text { Ln of } \text { assets }_{i, t}+\text { MtoBratio }_{i, t} \\
& + \text { Compounded stock return }_{i, t}+\text { Firm age }_{i, t}+u_{i, t}
\end{aligned}
$$

Equity is defined as net equity issue ${ }^{24}$ scaled by beginning year book value of total assets by company $i$ in fiscal year $t$. As in Chang et al. (2009), firm-years in which the net equity issue or net debt issue ${ }^{25}$ exceeds $5 \%$ of the beginning balance of the firm's total assets are included in the sample; years in which both are $5 \%$ or neither is above the $5 \%$ cutoff are not included in the model. INTERNAL is an indicator variable, which takes a

\footnotetext{
${ }^{24}$ Net equity issue $=($ Sale of Common and Preferred Stock- Purchase of Common and Preferred Stock $) / \mathrm{TA}_{\mathrm{t}}-$ 1

${ }^{25}$ Net debt issue $=($ Long Term Debt Issuance-Long Term Debt Reduction + Current Debt Changes $) / \mathrm{TA}_{\mathrm{t}-1}$
} 
value of 1 , if the appointed CFO is promoted and 0 , if the appointed CFO is hired from the external labor market. The definition of the variables is provided in the appendix.

Governance cannot be put in the regression because of the reasons stated above. The coefficient for INTERNAL captures both effects. In this type of specification, endogeneity can arise potentially from two sources ${ }^{26}$ : a) omitted variable bias (in this case, one or more independent variables are correlated with error term, thus, violates the condition for OLS) and b) when an independent variable is a function of the dependent variable. In order to tackle endogeneity, I use instrumental regression and estimate the model by 2SLS (2-stage least squares), GMM (generalized method of moments) with robust standard errors, and GMM clustered by 2-digit SIC. I use the industry CFO ratio as the instrument. A similar instrument is used in Balsam et al. (2016). I have included all potential variables that can affect a firm's choice of equity issue. These variables are chosen consulting extant literature. The model is controlled for clustering based on their 2-digit industry classification in order to take out biases from the model due to a clustering effect, if any. I also used Fama-French 48 industry classification ${ }^{27}$, and the results remained the same.

The notion that the CFO improves firm governance by providing timely and accurate information can be captured by incorporating information asymmetry. If the

\footnotetext{
${ }^{26}$ There is another source when variables are measured incorrectly, or from measurement error bias. As I use all the variables from COMPUSTAT, CRSP, IEBS, and other established data sources and follow the literature to define the variables used in the study, there is no or minimal measurement error. Usually measurement error arises from statistical estimation. I did not use any estimated variables in this specification.

${ }^{27}$ I follow Fama French 48 industry classification. The code for industry classification has been obtained from http://faculty-gsb.stanford.edu/deHaan/documents/industries ff12.txt. The results are not reported in the paper, however, they are available upon request.
} 
internally promoted CFO has a better knowledge of the firm's reporting policies and knows the investor clientele, s/he should have an influence on information asymmetry (which will have an impact on governance ${ }^{28}$ ) and firm equity issue. Therefore, I can combine equation 4 and equation 5 and assess the impact of INTERNAL on firm equity choice, while the CFO reduces information asymmetry:

$$
\begin{aligned}
& \text { Equity }_{i, t}= \\
& \text { INTERNAL } L_{i, t}+\text { InfAsym }+ \text { INTERNAL } * \text { Inf Asym }+ \text { Tangibility }_{i, t} \\
& + \text { Levratio }_{i, t}+\text { ROA }_{i, t}+\text { Sharetrunover }_{i, t}+\text { Fin. }_{\text {. }} \text { size }_{i, t} \\
& + \text { Debtrating }_{i, t}+\text { No. of } \text { analyst }_{i, t}+{\text { Earn. } \text { volatility }_{i, t}} \\
& + \text { Returnvolatility }_{i, t}+\text { Ln of } \text { assets }_{i, t}+\text { MtoBratio }_{i, t} \\
& + \text { Compounded stock return }_{i, t}+\text { Firm age }_{i, t}+u_{i, t}
\end{aligned}
$$

Information asymmetry is represented by Bid-Ask Spread and is calculated for each stock as follows:

$$
\text { Bid-Ask Spread }=\frac{\sum_{\mathrm{i}=1}^{\mathrm{T}} \text { Closing Ask }_{\mathrm{d}}-\text { Closing Bid }_{\mathrm{d}}}{\mathrm{T}}
$$

Where, the daily closing bid price is subtracted from the daily closing ask price and divided by the number of trading days $(=\mathrm{T})$ in a year. In the presence of information asymmetry, if INTERNAL significantly affects firm equity choice, then my earlier argument that CFOs reduce information asymmetry, improve governance, and issue equity holds. Moreover, equation (6) works as a robustness check for equation (5).

\subsubsection{Alternative Model}

I also do an alternative specification. I use a probit model using only the significant variables from the multiple regression framework (equation 5). I define the dependent

\footnotetext{
${ }^{28}$ As I show earlier that I do not need to explicitly model the improvement of governance and equity issue together in the presence of the internal CFO.
} 
variable either 1 or 0 ; it takes a value of 1 , if a firm issues more than $5 \%$ equity in any year and 0 , if it issues more than 5\% debt in any year. The reason I do a probit model is to estimate the probability of issuing equity by an internally promoted CFO. I have the following specification:

$\pi\left(\right.$ EquityIssue $\left._{i, t}=1\right)=f\left(\alpha_{0}+\alpha_{1}\right.$ Internal $_{i, t}+\sum_{i=2}^{N} \alpha_{i}$ Controls $\left._{i, t}+u_{i, t}\right)$

The $\pi$ on the left-hand side indicates the probability of equity issue by company $i$ at fiscal year $t$. The coefficient, $\alpha_{1}$ captures the probability of issuing equity. The control variables are significant (5\% or less) from the multiple regression framework (equation 5). 2.5 Results

Table 2.1 reports the descriptive statistics. It includes mean, standard deviation, and minimum and maximum values of the variables I use in the study. On average, the sample firms issue bigger sized debt than equity. The mean value for debt issue is $11.90 \%$ (of beginning book value of assets) with minimum and maximum of $-24.60 \%$ and $82.30 \%$, respectively. On the contrary, the mean value of equity issue is $2.80 \%$ with minimum and maximum of $-41.00 \%$ and $76.30 \%$. The negative minimum values indicate repurchase of shares and repayments of debt. The average firm age is 14.89 years with the oldest firm having 62 years. About half of the firms have a rating history by Standard and Poor's. The mean industry leverage ratio is $33.80 \%$, which means that most of the firms have a $30: 70$ leverage ratio (about $30 \%$ of the firm's assets are financed by debt, while $70 \%$ of the assets are financed by equity). This ratio also tells us that firms have room to go for more equity if need be.

Table 2.2 reports the correlations between the variables. I will mainly discuss the correlations between equity issue and other variables. Also, I will focus on the correlation 
of internal CFOs with other variables. Firm equity choice and internal CFOs has a significant correlation of 0.14 , however, internal CFOs and governance (e-index) has a significant negative correlation $(=-0.24)$, meaning that internal CFOs contribute to improve governance and increase a firm's equity choice. However, from the correlation coefficient alone, causality cannot be established. I analyze the causal relation between internal CFOs and other key variables in the latter sections. Firm equity choice and internal CFOs have similar correlations with other variables. From mere observation of the correlation values of internal CFOs with other variables, I conjecture that the internal CFO is an important variable to explore.

Table 2.3 includes the student's $t$-test for two variables: debt issue and equity issue based on two categories of CFO appointments: CFOs promoted within the firms and CFOs hired from external labor market. Panel A reports the test for debt issue and panel B for equity issue. For debt issue, the two groups do not differ much (only 1.40\%). Before running the actual $t$-test, I first run the equality of the variance test. The null hypothesis for the equality of the variance test is that the two groups have identical variance in terms of the debt issue. At the $10 \%$ level, I reject the null hypothesis and use the Satterthwaite method of $t$-test. The $t$-statistic is 1.30 , therefore, I fail to reject the null hypothesis that the two groups have similar (mean) debt issue size. For equity issue, I follow the same test procedure: first, I conduct the equality of the variance test and then the student's $t$-test. The F-value for "folded F" test is 1.28 , therefore, I reject the null of equality of variance and use Satterthwaite method for $t$-test. I reject the null hypothesis that the equity issue size (\% of assets) is similar for the two groups; the $t$-statistic is 4.68 , which is significant at less 
than $1 \%$ level. From this point, I will focus on the equity issue rather than the debt issue for the sample firms.

In Table 2.4, I divide all the variables based on whether the firm promoted its CFO or hired CFO from an external labor market. I follow the same student's $t$-test methodology as described earlier for all the variables tested. Column 1 includes the name of the variables; column 2-3 and column 4-5 report mean and standard deviation for the two groups. Column 6 reports the mean difference (=mean value for the external CFOs-mean value for the internal CFOs) between the two groups. Column seven and eight report the $t$-statistic and statistical significance, respectively. "N/A" is used for no statistical significance between two groups. Among almost all of the variables, the groups differ from each other except in volatility of earnings, volatility of returns, and the industry leverage ratio. The mean value for governance under external CFO is more than 1 (i.e, 1.21), which means on average external CFO appointed firms have at least one of the six entrenchment provisions present. On the contrary, internally appointed CFO firms have an entrenchment value less than 1 (i.e., 0.54), which means the majority of the internally appointed firms have better governance than their counterparts. These two groups of firms significantly differ in terms of governance; $t$-statistic is 7.91 , which rejects the null hypothesis of same governance between two groups at $1 \%$ or less.

The leverage ratio between two groups of firms significantly differs. On average, external CFO appointed firms have $38 \%$ leverage, whereas internally promoted CFOs have $33 \%$ leverage ratio. The lower leverage ratio for an internal firm allows them more room to increase the debt in the future. Internal CFO appointing firms are younger than the external appointing firms; the average age of the internal CFO appointing firms is 12.72 
years $[=\operatorname{EXP}(2.543)]$, whereas the mean age of the firms appointing external CFOs is approximately 17.43 year $[=\operatorname{EXP}(2.858)]$. Due to being older, the older firms have more analysts following them, and more of them are rated by S\&P as seen in the debt rating.

Table 2.5 reports the triangular relation in the equity issue, governance, and internal CFOs. In equation (2), I have shown that internal CFOs significantly improve governance by reducing the entrenchment of a firm. The third column in the table shows that internal CFOs reduce entrenchment by 0.67 units, which is statistically significant at $1 \%$ level. Governance could possibly affect equity issue of firms. The problem is if I put both internal and proxy for governance (entrenchment index) as RHS variables to define a firm's equity choice when governance is a function of internal CFOs, then the coefficient will be biased. Therefore, the simple way around this is to use only internal CFOs, which capture both its own effect (direct) and governance effect (indirect), and the coefficient would be unbiased. In column two, when I put them together, both of them are statistically significant with right signs: 1-unit increase of governance (or decrease of entrenchment by one provision) would increase a firm's equity size by $1.90 \%$. On the other hand, promoting an internal CFO will increase a firm's equity size by $3.30 \%$, which is a biased estimate. In column four, I put only internal (refer to Equation \#3) to capture both internal and governance effect on a firm's equity choice, I find internal CFOs increase a firm's equity by $4.60 \%$ which is an unbiased estimate. ${ }^{29}$ The fifth column includes the firm-fixed effect (fe) model. The results are similar to that from OLS. The coefficient for internal CFO is a little bit higher than the OLS, $4.70 \%$.

${ }^{29}$ The properties of a true estimator are: best, linear, and unbiased estimator (BLUE). 
In the last column, I report the output from equation (4). In the presence of information asymmetry, internal CFOs still positively (and significantly) affect the firm equity issue. The coefficient of INTERNAL is 0.068 with a $t$-value of 4.78 . In the next section, I will shed light on the relation of the equity issue and internal CFOs in a multiple regression framework.

Table 2.6 reports outputs from four estimation processes: OLS, 2SLS-IV, GMMRobust and GMM-Cluster. In the second column, OLS output is reported. My variable of interest—internal CF — has a significant positive effect on a firm's equity choice. OLS here may not be BLUE (best linear unbiased estimator) due to endogeneity. In this specification, endogeneity can generate from two sources: a) internal CFO affects equity and at the same time, a firm which wants to issue equity appoints/promotes internals as CFOs, and b) omitted variables. In order to handle the endogeneity issue, I use instrumental variable (IV) regressions. Following Balsam et al. (2016), I use the industry CFO ratio as an instrument. Finding a good instrument is always a challenge. A good instrument should not be correlated with the dependent variable, a firm's equity issue, however, it should be positively correlated with internal CFOs. I defined the proportion of firms (excluding the sample firms) in the industry (2-digit SIC) that employ internal or external candidates as CFOs. I test the validity or strength of the defined instrument. The partial F-statistic 45.66 and the $\mathrm{R}^{2}$ in the first stage (regressing internal on industry $\mathrm{CFO}$ ratio) is $17.60 \%$, which indicates the instrument has sufficient power in explaining a firm's internal CFOs choice. I use three estimation techniques: 2SLS (two stage least squares), GMM (generalized method of moments) with robust standard errors, and GMM with clustering. 
Under 2SLS-IV, GMM-Robust and GMM-Cluster, internal CFOs are positive and significant on a firm's equity issue. The difference between 2SLS-IV and GMM robust is that GMM robust penalizes by assigning higher standard errors. The standard error for INTERNAL under 2SLS is 0.037 and under GMM robust it is 0.040 . The other significant variables that affect a firm's equity size are leverage, ROA, finance size, number of analysts, return volatility, and compounded stock returns. Leverage, ROA, and number of analysts affect a firm's equity negatively. Higher levered firms will not go for equity because it is riskier for the new investors to buy stocks of a firm, which is already highly leveraged. If the firm has a higher return, it does not need external financing; it can use its internal finance or retained earnings. A similar finding is reported by Chang et al. $(2009)^{30}$. The coefficient for the number of analysts is a little unexpected. Usually, more analysts should enhance a firm's credibility among investors to sell equity. However, in this scenario, it may be the case that as more and more analysts start following a firm, the better the credit rating goes, which eventually entices the firm to go for the debt financing. This is a plausible explanation as we have seen that lowly leveraged firms appoint internals as CFOs (refer to Table 2.4).

Finance size is the amount of money needed from external sources. This should be positively related with equity financing because equity is a major component of external financing. In the equity issue process, firms take advantage of timing. For example, Greenwood (2005) shows that firms issue equity when they think their stocks are overvalued in the market. Both the return volatility and compounded returns are positively

\footnotetext{
${ }^{30}$ See Table 5, p.1105.
} 
affecting equity issue of the firm, and so justifies the market timing. At good times, firms may issue equity and at bad times, firms may buy back (or repurchase) some existing equity. Therefore, return volatility is positively related with firms' equity choice.

Table 2.7 reports the influence of internal CFOs on firm equity choice in the presence of information asymmetry (refer to equation 6). The CFO being the second responsible person for financial reporting can significantly improve governance by reducing information asymmetry (IA). In all four models, INTERNAL is significant (at 1\% or less) and positive, which means internal CFOs can reduce information asymmetry. Information asymmetry improves firm governance, which in turn incentivizes the firms to go for equity financing. The interaction term, INTERNAL*IA, is significant and negative, which ensures my earlier proposition that internal CFOs can improve firm governance by reducing information asymmetry. The other significant variables are: leverage ratio, ROA, finance size, number of analysts, volatility of returns, and compounded returns.

Table 2.8 provides the results from alternative specification and the probit model, using the significant variables (at least $5 \%$ level of significance) from multiple regressions. The significant variables are: internal CFO, leverage ratio, ROA, financing size, share turnover, number of analysts, volatility of stock returns, and compounded returns. Unlike previous models, the probit model gives an estimated probability of happening of a dependent variable, which take a value of either 1 or 0 ) by a specific independent variable. Table 2.8, Panel A provides a probabilistic outcome, whereas Panel B provides an effect outcome at the mean. In both scenarios, internal CFO is significant and positive. Output from the probit model says that there is a $20 \%$ higher probability for an internal CFO to issue equity than an external CFO. Output from a marginal effect at the mean is saying an 
internal CFO would issue equity about $5.40 \%$ of total assets within a year s/he takes office. This finding is consistent with the findings from the multiple frameworks discussed in the earlier section.

\subsection{Conclusion}

In this essay, I show that firms with internal CFO appointments take the advantage of going into the stock market within one year of such appointments. This finding is robust under various specifications. The internal CFOs act as a conduit to improve a firm's governance mechanism by significantly reducing information asymmetry, and firms try to take advantage of CFO appointments by issuing equity. I use the entrenchment index created by Bebchuk et al. (2008), which has been widely used as a parameter for firm governance. I find that an internal CFO simultaneously reduces information asymmetry and solicits funds by selling equity. Firms that promote an internal as the CFO are also younger, lowly leveraged, and have better growth prospects than the firms that hire the CFO from external labor markets.

What do firms do with the funds collected from the stock market? I cannot answer that question explicitly without further analysis. Firms submit $S$-filings before equity issue and will have to mention the specific reason(s) for the equity issue. The reasons mentioned in the S-filings are to invest, to retire some existing debt, or for general corporate purpose. The last reason is a little bit ambiguous. Walker and Yost (2008) show that the stock market reacts favorably in the scenario where firms use the proceeds from stock repurchase for further investment and provide investors with specific plans of such investment. Without knowing the motive of the equity issue, I cannot say why the stock market reacted favorably for the equity issue by an internal CFO. I leave this interesting issue for future endeavors. 
Figure 2.1 Why I have defined internal CFO as having year-difference is $>=2$ years Firm A (1-year difference):

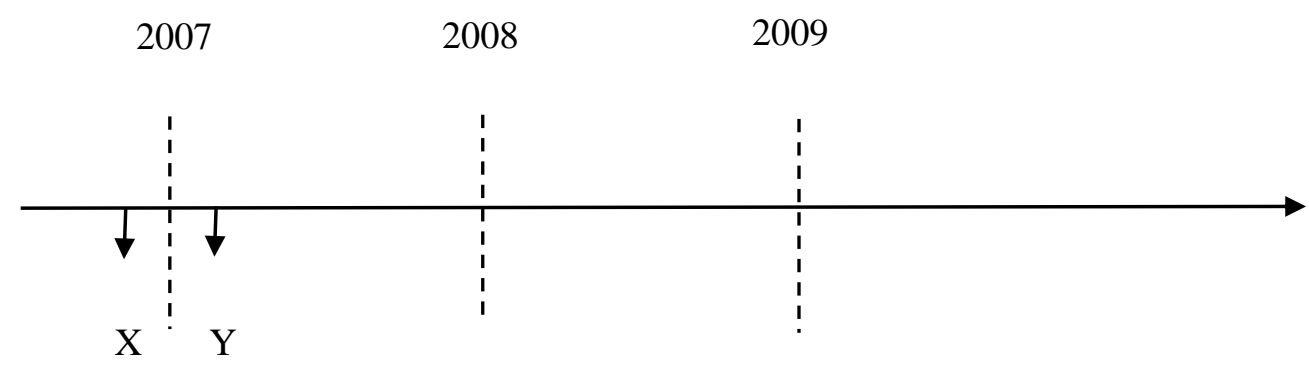

$\begin{array}{llll}\text { Reported as } & \text { Reported } & \text { Reported } & \mathrm{X}=\text { first hired } \\ \text { Non-CFO } & \text { as CFO } & \text { as CFO } & \mathrm{Y}=\text { promoted to CFO } \\ & & ----=\text { Reported to EXECUCOMP }\end{array}$

Firm B (2-year difference):

\begin{tabular}{|c|c|c|}
\hline 2007 & 2008 & 2009 \\
\hline $\begin{array}{l}1 \\
1 \\
1\end{array}$ & $\begin{array}{l}1 \\
1 \\
1\end{array}$ & ! \\
\hline $\begin{array}{ll}1 & 1 \\
7 & 1 \\
X & 1\end{array}$ & $\begin{array}{ll}1 \\
1 \\
1\end{array}$ & $\begin{array}{l}1 \\
1 \\
1\end{array}$ \\
\hline $\begin{array}{l}\text { Reported as } \\
\text { Non-CFO }\end{array}$ & $\begin{array}{l}\text { Reported as } \\
\text { Non-CFO }\end{array}$ & $\begin{array}{l}\text { Reported } \\
\text { as CFO }\end{array}$ \\
\hline
\end{tabular}


Table 2.1 Descriptive Statistics

This table reports the descriptive statistics of the variables used in the study. On average, the sample companies issue more debt than equity (11.80\% versus $3.10 \%)$. The sample has almost half and half distribution of EXTERNAL and INTERNAL CFOs. All the variables are winsorized at $1 \%$ and $99 \%$ level (except indicator or dummy variables).

\begin{tabular}{|c|c|c|c|c|c|}
\hline Variable & NOBS & Mean & Std. Dev. & Min & Max \\
\hline Debt percent & 1,045 & 0.119 & 0.177 & -0.246 & 0.823 \\
\hline Equity percent & 1,045 & 0.028 & 0.160 & -0.410 & 0.763 \\
\hline INTERNAL & 1,045 & 0.495 & 0.500 & 0.000 & 1.000 \\
\hline Ln of assets & 1,045 & 6.996 & 1.532 & 3.543 & 11.127 \\
\hline Tangibility & 1,043 & 0.306 & 0.236 & 0.013 & 0.902 \\
\hline Leverage ratio & 1,043 & 0.359 & 0.210 & 0.017 & 0.905 \\
\hline ROA & 1,045 & 0.016 & 0.153 & -0.907 & 0.276 \\
\hline Market-to-book ratio & 1,044 & 2.129 & 1.481 & 0.788 & 8.961 \\
\hline Financing size & 1,045 & 0.098 & 0.107 & -0.195 & 0.408 \\
\hline Share turnover & 966 & 1.986 & 1.559 & 0.192 & 8.142 \\
\hline Ln of firm age & 1,040 & 2.701 & 0.830 & 0.000 & 4.127 \\
\hline Debt rating & 1,045 & 0.464 & 0.499 & 0.000 & 1.000 \\
\hline Number of analyst & 1,045 & 10.283 & 9.740 & 0.000 & 41.000 \\
\hline Earnings volatility & 734 & 0.068 & 0.074 & 0.010 & 0.466 \\
\hline Return volatility & 966 & 0.030 & 0.015 & 0.010 & 0.085 \\
\hline Compounded return & 964 & 0.238 & 0.888 & -0.846 & 5.545 \\
\hline Industry leverage ratio & 1,045 & 0.338 & 0.143 & 0.074 & 0.715 \\
\hline Industry Internal CFO ratio & 1,045 & 0.025 & 0.024 & 0.000 & 0.121 \\
\hline
\end{tabular}




\section{Table 2.2 Correlations}

This table reports the correlations between the variables. The correlations between internal CFOs and equity size and between internal CFOs and governance is significantly positive and negative, respectively. That means internal CFO appointment is positively associated with equity issue and negatively associated with governance. The values in bold are significant at $5 \%$ or lower.

\begin{tabular}{|c|c|c|c|c|c|c|c|c|c|c|c|c|c|c|c|c|c|c|}
\hline & 1 & 2 & 3 & 4 & 5 & 6 & 7 & 8 & 9 & 10 & 11 & 12 & 13 & 14 & 15 & 16 & 17 & 18 \\
\hline Equity & 1.00 & & & & & & & & & & & & & & & & & \\
\hline INTERAL & 0.14 & 1.00 & & & & & & & & & & & & & & & & \\
\hline Governance & -0.19 & -0.24 & 1.00 & & & & & & & & & & & & & & & \\
\hline B-A Spread & 0.09 & 0.42 & -0.25 & 1.00 & & & & & & & & & & & & & & \\
\hline Ln of assets & -0.37 & -0.18 & 0.23 & -0.19 & 1.00 & & & & & & & & & & & & & \\
\hline Tangibility & -0.02 & 0.06 & -0.04 & 0.09 & 0.06 & 1.00 & & & & & & & & & & & & \\
\hline Lev. ratio & -0.27 & -0.12 & 0.08 & -0.08 & 0.33 & 0.18 & 1.00 & & & & & & & & & & & \\
\hline ROA & -0.20 & 0.11 & 0.03 & 0.07 & 0.22 & -0.01 & -0.26 & 1.00 & & & & & & & & & & \\
\hline M-to-B ratio & 0.27 & 0.11 & -0.12 & 0.09 & -0.26 & -0.20 & -0.65 & 0.10 & 1.00 & & & & & & & & & \\
\hline Fin. size & 0.47 & 0.06 & -0.07 & 0.10 & -0.25 & -0.03 & 0.04 & -0.29 & -0.03 & 1.00 & & & & & & & & \\
\hline Share turn. & 0.13 & -0.15 & 0.09 & -0.33 & 0.02 & -0.07 & -0.09 & -0.05 & 0.17 & 0.05 & 1.00 & & & & & & & \\
\hline Ln_firm_age & -0.27 & -0.19 & 0.27 & -0.15 & 0.46 & 0.02 & 0.26 & 0.06 & -0.27 & -0.19 & -0.15 & 1.00 & & & & & & \\
\hline Debt rating & -0.24 & -0.10 & 0.17 & -0.06 & 0.65 & 0.13 & 0.37 & 0.04 & -0.24 & -0.15 & -0.03 & 0.39 & 1.00 & & & & & \\
\hline Num_analyst & -0.15 & -0.09 & 0.27 & -0.17 & 0.42 & 0.08 & -0.12 & 0.13 & 0.06 & -0.15 & 0.23 & 0.13 & 0.25 & 1.00 & & & & \\
\hline Ern. vola. & 0.29 & -0.05 & -0.06 & -0.11 & -0.42 & -0.08 & -0.19 & -0.39 & 0.33 & 0.18 & 0.24 & -0.33 & -0.28 & -0.06 & 1.00 & & & \\
\hline Ret. vola. & 0.36 & 0.04 & -0.14 & -0.02 & -0.42 & -0.04 & -0.02 & -0.42 & 0.21 & 0.19 & 0.40 & -0.32 & -0.27 & -0.16 & 0.34 & 1.00 & & \\
\hline Comp. rets. & 0.26 & 0.10 & -0.13 & 0.04 & -0.14 & -0.08 & -0.32 & 0.16 & 0.39 & 0.08 & 0.04 & -0.12 & -0.13 & -0.14 & 0.07 & 0.12 & 1.00 & \\
\hline Ind. lev. rat. & -0.19 & -0.01 & 0.10 & 0.01 & 0.24 & 0.28 & 0.59 & 0.00 & -0.42 & -0.08 & -0.11 & 0.17 & 0.24 & -0.03 & -0.24 & -0.06 & -0.15 & 1.00 \\
\hline
\end{tabular}

1=Equity percent, $2=$ Internal CFO, 3=Governance, 4=Bid-Ask Spread, 5= Ln of assets, 6= Tangibility, 7= Leverage ratio, $8=$ ROA, 9= Market-to-Book ratio, 10= Finance size, 11= Share turnover, 12= Ln of firm age, 13= Debt rating, 14= Number of analysts, $15=$ Earnings volatility, $16=$ Return volatility, 17= Compounded return, $18=$ Industry leverage ratio. 
Table 2.3 Debt-equity Choice by Internal and External CFOs

This table reports a firm's debt-equity choice of internal versus external CFOs. Internal $\mathrm{CFO}=1$ and external $\mathrm{CFO}=0$. First, I run the equality of variance test between these two groups of CFOs. I fail to reject the null hypothesis of equality of variance test at the $10 \%$ level of significance and therefore, I use Satterthwaite method for the $t$-test. Debt issue is not significantly different between the two groups of CFOs. On the contrary, equity issue is significant at $1 \%$ level ( $t$-value is 4.07). On average, internal CFOs issue $4.30 \%$ more equity in the year of appointment than external CFOs.

\begin{tabular}{|c|c|c|c|c|c|c|}
\hline \multicolumn{7}{|c|}{ Panel A: Debt issue (\%) } \\
\hline INTERNAL & $\mathrm{N}$ & Mean & St. Dev & St. Err & Minimum & Maximum \\
\hline 0 & 528 & 0.126 & 0.171 & 0.007 & -0.246 & 0.823 \\
\hline 1 & 517 & 0.112 & 0.184 & 0.008 & -0.246 & 0.823 \\
\hline Diff $(1-2)$ & & 0.014 & 0.177 & 0.011 & & \\
\hline Method & Variances & $\mathrm{DF}$ & t Value & $\operatorname{Pr}>|t|$ & & \\
\hline Pooled & Equal & 1043.000 & 1.300 & 0.194 & & \\
\hline Satterthwaite & Unequal & 1034.100 & 1.300 & 0.194 & & \\
\hline \multicolumn{7}{|c|}{ Equality of Variances } \\
\hline Method & Num DF & Den DF & F Value & $\operatorname{Pr}>\mathrm{F}$ & & \\
\hline Folded F & 516.000 & 527.000 & 1.160 & 0.100 & & \\
\hline \multicolumn{7}{|c|}{ Panel B: Equity issue (\%) } \\
\hline INTERNAL & $\mathrm{N}$ & Mean & St. Dev & St. Err & Minimum & Maximum \\
\hline 0 & 528 & 0.006 & 0.148 & 0.006 & -0.410 & 0.763 \\
\hline 1 & 517 & 0.051 & 0.168 & 0.007 & -0.410 & 0.763 \\
\hline Diff (1-2) & & -0.046 & 0.158 & 0.010 & & \\
\hline Method & Variances & DF & t Value & $\operatorname{Pr}>|t|$ & & \\
\hline Pooled & Equal & 1043 & -4.69 & $<.0001$ & & \\
\hline Satterthwaite & Unequal & 1022 & -4.68 & $<.0001$ & & \\
\hline \multicolumn{7}{|c|}{ Equality of Variances } \\
\hline Method & Num DF & Den DF & F Value & $\operatorname{Pr}>F$ & & \\
\hline Folded F & 516 & 527 & 1.28 & 0.005 & & \\
\hline
\end{tabular}


Table 2.4 T-test on Other Variables between Two Groups

This table reports all of the important variables that I use in the study and the difference between the two groups of CFOs. Sixth column is the mean difference (=external CFOinternal CFO) between the two groups of CFOs. Column 7 is a t-statistic from t-tests, where the null hypothesis is the mean difference of zero between the two groups. I first used the folded F-test to test for the equality of variance and then run the t-test. If I fail to reject the null hypothesis in the Folded F-test, then I use the "Pooled method" of t-test. However, if I reject the null in the folded F-test, then I used the "Satterthwaite method." The last column delineates the significance level.

\begin{tabular}{lccccccc}
\hline \multicolumn{1}{c}{$\begin{array}{c}\text { External CFO } \\
(1)\end{array}$} & \multicolumn{2}{c}{$\begin{array}{c}\text { Internal CFO } \\
(2)\end{array}$} & & & & \\
\hline Variable & Mean & SD & Mean & SD & $\begin{array}{c}\text { Diff }(1- \\
2)\end{array}$ & $\begin{array}{c}t \text { - } \\
\text { value }\end{array}$ & $\begin{array}{c}\text { Signifi } \\
\text { cance }\end{array}$ \\
\hline E-Index & 1.208 & 1.560 & 0.542 & 1.136 & 0.667 & 7.91 & $* * *$ \\
Ln of assets & 7.268 & 1.581 & 6.719 & 1.428 & 0.550 & 5.90 & $* * *$ \\
Tangibility & 0.291 & 0.231 & 0.321 & 0.240 & -0.030 & -2.05 & $* *$ \\
Leverage ratio & 0.384 & 0.208 & 0.334 & 0.210 & 0.050 & 3.86 & $* * *$ \\
ROA & -0.001 & 0.173 & 0.034 & 0.127 & -0.035 & -3.70 & $* * *$ \\
Market-to-Book ratio & 1.965 & 1.241 & 2.296 & 1.676 & -0.331 & -3.62 & $* * *$ \\
Financing size & 0.092 & 0.109 & 0.105 & 0.106 & -0.012 & -1.85 & $*$ \\
Share turnover & 2.214 & 1.548 & 1.748 & 1.537 & 0.466 & 4.69 & $* * *$ \\
Ln of firm age & 2.858 & 0.758 & 2.543 & 0.869 & 0.314 & 6.21 & $* * *$ \\
Debt rating & 0.511 & 0.500 & 0.416 & 0.493 & 0.096 & 3.11 & $* * *$ \\
Number of analyst & 11.197 & 10.096 & 9.350 & 9.281 & 1.847 & 3.08 & $* * *$ \\
Volatility of earnings & 0.071 & 0.084 & 0.064 & 0.058 & 0.007 & 1.31 & N/A \\
Volatility of return & 0.030 & 0.016 & 0.031 & 0.014 & -0.001 & -1.32 & N/A \\
Compounded return & 0.148 & 0.798 & 0.332 & 0.964 & -0.183 & -3.21 & $* * *$ \\
Industry leverage & 0.339 & 0.138 & 0.336 & 0.147 & 0.003 & 0.31 & N/A \\
ratio & & & & & & & \\
\hline
\end{tabular}


Table 2.5 Effect of Internal CFO on Governance and Equity Issue

The following table includes the effect of internal CFO appointments on the firm's governance and equity issue based on the specification discussed in equations 1-3. When I put both internal and governance (e-index) as dependent variables to determine the effect on firm's equity issue, I essentially get a biased coefficient for internal. Because the internal CFO improves firm governance (or equivalently governance is a function of INTERNAL), I cannot use both of them as RHS variables. When I use INTERNAL as the only RHS variable, the coefficient includes both the direct and the indirect (due to governance) effect on firm's equity choice. The fifth column reports the firm-fixed model. The last column shows influence of INTERNAL on firm equity issue in the presence of information asymmetry (IA). IA is represented by bid-ask spread. The $t$-statistic is in the parenthesis. $* * *, * *, *$ indicate $1 \%, 5 \%$ and $10 \%$ statistical level of significance.

\begin{tabular}{|c|c|c|c|c|c|}
\hline & $\begin{array}{c}\text { Equation } \\
\quad \# 1 \\
\text { Dep. Var.: } \\
\text { Equity } \\
\text { size }\end{array}$ & $\begin{array}{c}\text { Equation } \\
\quad \# 2 \\
\text { Dep. Var.: } \\
\text { Governan } \\
\text { ce }\end{array}$ & $\begin{array}{c}\text { Equation } \\
\text { \#3 } \\
\text { Dep. Var.: } \\
\text { Equity } \\
\text { size }\end{array}$ & $\begin{array}{c}\text { Equation } \\
\# 3, \text { fe } \\
\text { Dep. Var.: } \\
\text { Equity } \\
\text { size }\end{array}$ & $\begin{array}{c}\text { Equation } \\
\quad \# 4 \\
\text { Dep. Var.: } \\
\text { Equity } \\
\text { size }\end{array}$ \\
\hline Governance & $\begin{array}{c}-0.019 * * * \\
(-5.30)\end{array}$ & & & & \\
\hline INTERNAL & $\begin{array}{c}0.033 * * * \\
(3.36)\end{array}$ & $\begin{array}{c}-0.667 * * * \\
(-7.88)\end{array}$ & $\begin{array}{c}0.046^{* * * *} \\
(4.69)\end{array}$ & $\begin{array}{c}0.047 * * * \\
(4.90)\end{array}$ & $\begin{array}{c}0.068 * * * \\
(4.78)\end{array}$ \\
\hline Infor. Asymm. (IA) & & & & & $\begin{array}{c}0.098 * * \\
(2.30)\end{array}$ \\
\hline INTERNAL*IA & & & & & $\begin{array}{c}-0.117 * * \\
(-2.27)\end{array}$ \\
\hline Constant & $\begin{array}{c}0.028 * * * \\
(3.52)\end{array}$ & $\begin{array}{c}1.208 * * * \\
(20.31)\end{array}$ & $\begin{array}{l}0.006 \\
(0.81)\end{array}$ & $\begin{array}{l}0.005 \\
(0.73)\end{array}$ & $\begin{array}{l}-0.006 \\
(-0.73)\end{array}$ \\
\hline R-squared & 0.046 & 0.056 & 0.021 & 0.021 & 0.032 \\
\hline N. of OBS & 1,045 & 1,045 & 1,045 & 1,045 & 966 \\
\hline
\end{tabular}


Table 2.6 Internal CFO and Firm Equity Choice

This table reports the relation between internal CFOs and firm equity issue in multiple regression framework. Four models are reported here. In the second column, simple OLS output is reported. In the third to fifth column, instrumental regression under 2SLS, GMM with robust standard errors (assigned a positive definite weight matrix) and clustered (by 2-digit industry) GMM estimation processes are reported. In all four specifications, internal CFO is significant. Under the instrumental regression estimations, the coefficient is unbiased. Standard errors are reported in the parenthesis. ***,**,* indicate $1 \%, 5 \%$ and $10 \%$ statistical level of significance.

\begin{tabular}{|c|c|c|c|c|}
\hline $\begin{array}{l}\text { Dependent variable: } \\
\text { equity }(\%)\end{array}$ & OLS & 2SLS-IV & $\begin{array}{l}\text { GMM } \\
\text { Robust }\end{array}$ & $\begin{array}{l}\text { GMM SIC } \\
\text { Cluster }\end{array}$ \\
\hline \multirow[t]{2}{*}{ INTERNAL } & $0.022 * *$ & $0.115 * * *$ & $0.115^{* * *}$ & $0.115^{* * *}$ \\
\hline & $(0.009)$ & $(0.037)$ & $(0.040)$ & $(0.036)$ \\
\hline \multirow[t]{2}{*}{ Ln of assets } & -0.006 & -0.001 & -0.001 & -0.001 \\
\hline & $(0.005$ & -0.006 & -0.005 & -0.005 \\
\hline \multirow[t]{2}{*}{ Tangibility } & 0.020 & -0.001 & -0.001 & -0.001 \\
\hline & $(0.019)$ & -0.021 & -0.020 & -0.020 \\
\hline \multirow[t]{2}{*}{ Leverage ratio } & $-0.121 * * *$ & $-0.129 * * *$ & $-0.129 * * *$ & $-0.129 * * *$ \\
\hline & -0.031 & -0.034 & -0.033 & -0.031 \\
\hline \multirow[t]{2}{*}{ ROA } & $-0.088 * *$ & $-0.155^{* * *}$ & $-0.155^{* *}$ & $-0.155^{* * *}$ \\
\hline & -0.037 & -0.048 & -0.066 & -0.051 \\
\hline \multirow[t]{2}{*}{ Market-to-market ratio } & 0.001 & -0.001 & -0.001 & -0.001 \\
\hline & $(0.005)$ & -0.005 & -0.007 & -0.005 \\
\hline \multirow[t]{2}{*}{ Finance size } & $0.504 * * *$ & $0.471 * * *$ & $0.471 * * *$ & $0.471 * * *$ \\
\hline & -0.045 & -0.049 & -0.080 & -0.056 \\
\hline \multirow[t]{2}{*}{ Share turnover } & 0.006 & $0.014 * * *$ & $0.014 * *$ & $0.014 * * *$ \\
\hline & -0.004 & -0.005 & -0.005 & -0.005 \\
\hline \multirow[t]{2}{*}{ Ln of firm age } & 0.003 & 0.009 & 0.009 & 0.009 \\
\hline & -0.009 & -0.009 & -0.009 & -0.010 \\
\hline \multirow[t]{2}{*}{ Debt rating } & 0.003 & -0.002 & -0.002 & -0.002 \\
\hline & -0.011 & -0.012 & -0.012 & -0.012 \\
\hline \multirow[t]{2}{*}{ Number of analysts } & $-0.001 *$ & $-0.001 * *$ & $-0.001 * * *$ & $-0.001 * *$ \\
\hline & -0.001 & -0.001 & -0.001 & -0.001 \\
\hline \multirow[t]{2}{*}{ Earnings volatility } & 0.080 & 0.089 & 0.089 & $0.089 *$ \\
\hline & -0.073 & -0.078 & -0.099 & -0.053 \\
\hline \multirow[t]{2}{*}{ Return volatility } & $1.509 * * *$ & $1.244 * * *$ & $1.244 * * *$ & $1.244 * * *$ \\
\hline & -0.397 & -0.437 & -0.413 & -0.377 \\
\hline \multirow[t]{2}{*}{ Compounded return } & $0.021 * * *$ & $0.022 * * *$ & $0.022 * * *$ & $0.022 * * *$ \\
\hline & -0.006 & -0.007 & -0.008 & -0.007 \\
\hline \multirow[t]{2}{*}{ Constant } & -0.028 & $-0.112 * *$ & $-0.112 * *$ & $-0.112 * *$ \\
\hline & -0.043 & -0.056 & -0.054 & -0.056 \\
\hline R-squared & 0.369 & 0.263 & 0.263 & 0.263 \\
\hline NOBS & 672 & 672 & 672 & 672 \\
\hline
\end{tabular}


Table 2.7 Internal CFO and Information Asymmetry

This table reports the relation between internal CFOs with firm information asymmetry and firm equity issue in multiple regression framework. Four models are reported here. In the second column, simple OLS output is reported. In the third to fifth column, instrumental regression under 2SLS, GMM with robust standard errors (assigned a positive definite weight matrix) and clustered (by 2-digit industry codes) GMM estimation processes are reported. In all four specifications, internal CFO is significant. Under the instrumental regression estimations, the coefficient is unbiased. Standard errors are reported in the parenthesis. $* * *, * *, *$ indicate $1 \%, 5 \%$ and $10 \%$ statistical level of significance.

\begin{tabular}{|c|c|c|c|c|}
\hline & OLS & 2SLS IV & $\begin{array}{l}\text { GMM } \\
\text { Robust }\end{array}$ & $\begin{array}{c}\text { GMM SIC } \\
\text { Cluster }\end{array}$ \\
\hline INTERNAL & $\begin{array}{c}0.033 * * * \\
(0.012)\end{array}$ & $\begin{array}{c}0.108 * * * \\
(0.033)\end{array}$ & $\begin{array}{c}0.108 * * * \\
(0.035)\end{array}$ & $\begin{array}{c}0.108 * * * \\
(0.033)\end{array}$ \\
\hline Information asymmetry (IA) & $\begin{array}{c}0.032 \\
(0.038)\end{array}$ & $\begin{array}{c}0.110 * * \\
(0.050)\end{array}$ & $\begin{array}{c}0.110^{* *} \\
(0.051)\end{array}$ & $\begin{array}{c}0.110 * * * \\
(0.041)\end{array}$ \\
\hline INTERNAL*IA & $\begin{array}{l}-0.058 \\
(0.044)\end{array}$ & $\begin{array}{c}-0.227 * * * \\
(0.082)\end{array}$ & $\begin{array}{c}-0.227 * * * \\
(0.084)\end{array}$ & $\begin{array}{c}-0.227 * * * \\
(0.072)\end{array}$ \\
\hline Ln of assets & $\begin{array}{l}-0.006 \\
(0.005)\end{array}$ & $\begin{array}{l}-0.004 \\
(0.005)\end{array}$ & $\begin{array}{l}-0.004 \\
(0.005)\end{array}$ & $\begin{array}{l}-0.004 \\
(0.004)\end{array}$ \\
\hline Tangibility & $\begin{array}{c}0.02 \\
(0.019)\end{array}$ & $\begin{array}{c}0.013 \\
(0.019)\end{array}$ & $\begin{array}{c}0.013 \\
(0.018)\end{array}$ & $\begin{array}{c}0.013 \\
(0.019)\end{array}$ \\
\hline Leverage ratio & $\begin{array}{c}-0.121 * * * \\
(0.031)\end{array}$ & $\begin{array}{c}-0.124 * * * \\
(0.032)\end{array}$ & $\begin{array}{c}-0.124 * * * \\
(0.031)\end{array}$ & $\begin{array}{c}-0.124 * * * \\
(0.031)\end{array}$ \\
\hline ROA & $\begin{array}{c}-0.089 * * \\
(0.037)\end{array}$ & $\begin{array}{c}-0.121 * * * \\
(0.040)\end{array}$ & $\begin{array}{c}-0.121^{* *} \\
(0.056)\end{array}$ & $\begin{array}{c}-0.121 * * * \\
(0.047)\end{array}$ \\
\hline Market-to-market ratio & $\begin{array}{c}0.001 \\
(0.005)\end{array}$ & $\begin{array}{l}-0.001 \\
(0.005)\end{array}$ & $\begin{array}{l}-0.001 \\
(0.007)\end{array}$ & $\begin{array}{l}-0.001 \\
(0.005)\end{array}$ \\
\hline Finance size & $\begin{array}{c}0.501 * * * \\
(0.045)\end{array}$ & $\begin{array}{c}0.477 * * * \\
(0.047)\end{array}$ & $\begin{array}{c}0.477 * * * \\
(0.076)\end{array}$ & $\begin{array}{c}0.477 * * * \\
(0.055)\end{array}$ \\
\hline Share turnover & $\begin{array}{c}0.006 \\
(0.004)\end{array}$ & $\begin{array}{c}0.009 * * \\
(0.004)\end{array}$ & $\begin{array}{c}0.009 * * \\
(0.004)\end{array}$ & $\begin{array}{c}0.009 * * \\
(0.004)\end{array}$ \\
\hline Ln of firm age & $\begin{array}{c}0.003 \\
(0.009)\end{array}$ & $\begin{array}{c}0.006 \\
(0.009)\end{array}$ & $\begin{array}{c}0.006 \\
(0.008)\end{array}$ & $\begin{array}{c}0.006 \\
(0.009)\end{array}$ \\
\hline Debt rating & $\begin{array}{c}0.003 \\
(0.011)\end{array}$ & $\begin{array}{c}0.001 \\
(0.012)\end{array}$ & $\begin{array}{c}0.001 \\
(0.011)\end{array}$ & $\begin{array}{c}0.001 \\
(0.010)\end{array}$ \\
\hline Number of analysts & $\begin{array}{c}-0.001 * \\
(0.001)\end{array}$ & $\begin{array}{c}-0.001 * * \\
(0.001)\end{array}$ & $\begin{array}{l}-0.001 * * \\
(0.0005)\end{array}$ & $\begin{array}{l}-0.001 * * \\
(0.0005)\end{array}$ \\
\hline Earnings volatility & $\begin{array}{c}0.085 \\
(0.073)\end{array}$ & $\begin{array}{c}0.100 \\
(0.075)\end{array}$ & $\begin{array}{c}0.100 \\
(0.093)\end{array}$ & $\begin{array}{c}0.100^{* *} \\
(0.048)\end{array}$ \\
\hline Return volatility & $\begin{array}{c}1.463 * * * \\
(0.400)\end{array}$ & $\begin{array}{c}1.228 * * * \\
(0.419)\end{array}$ & $\begin{array}{c}1.228 * * * \\
(0.390)\end{array}$ & $\begin{array}{c}1.228 * * * \\
(0.340)\end{array}$ \\
\hline Compounded return & $\begin{array}{c}0.021 * * * \\
(0.006)\end{array}$ & $\begin{array}{c}0.021 * * * \\
(0.006)\end{array}$ & $\begin{array}{c}0.021 * * * \\
(0.007)\end{array}$ & $\begin{array}{c}0.021 * * * \\
(0.007)\end{array}$ \\
\hline Constant & $\begin{array}{l}-0.029 \\
(0.043)\end{array}$ & $\begin{array}{l}-0.069 \\
(0.047)\end{array}$ & $\begin{array}{l}-0.069 \\
(0.045)\end{array}$ & $\begin{array}{l}-0.069 \\
(0.044)\end{array}$ \\
\hline R-squared & 0.370 & 0.331 & 0.331 & 0.331 \\
\hline NOBS & 672 & 672 & 672 & 672 \\
\hline
\end{tabular}


Table 2.8 Internal CFO and Firm Equity Choice (Probit Model)

This table reports the results from the probit model (equation 5) using variables that are significant (5\% or less) under OLS and IV estimations (refer to Table 2.6). Unlike multiple regression, probit provides a probabilistic measure of a variable on the dependent variable instead of the extent of effects or coefficients. All eight variables are significant (refer to $\mathrm{P}>\mathrm{z}$ column) including the variable of interest, INTERNAL. Panel A provides probabilistic outcome, whereas Panel B provides effect outcome at the mean. In both scenarios, internal CFO is significant and positive. Output from probit model says that there is a $21 \%$ greater probability for an internal CFO to issue equity than an external CFO. Output from marginal effect is saying an internal CFO would issue equity about $6 \%$ of total assets after s/he takes office.

\begin{tabular}{|c|c|c|c|c|c|c|c|}
\hline & Coef. & $\begin{array}{l}\text { Std. } \\
\text { Err. }\end{array}$ & $\mathrm{z}$ & $\mathrm{P}>\mathrm{z}$ & $\begin{array}{l}{[95 \%} \\
\text { Conf. }\end{array}$ & Interval] & \\
\hline \multicolumn{8}{|l|}{ Panel A: Probit Output: } \\
\hline INTERNAL & 0.200 & 0.107 & 1.870 & 0.061 & -0.009 & 0.410 & \\
\hline Leverage ratio & -2.878 & 0.293 & -9.810 & 0.000 & -3.453 & -2.303 & \\
\hline ROA & -1.370 & 0.394 & -3.480 & 0.001 & -2.141 & -0.598 & \\
\hline Financing Size & -1.900 & 0.522 & -3.640 & 0.000 & -2.923 & -0.877 & \\
\hline Share turnover & 0.069 & 0.038 & 1.820 & 0.069 & -0.005 & 0.143 & \\
\hline Number of analysts & -0.018 & 0.006 & -2.960 & 0.003 & -0.029 & -0.006 & \\
\hline Return Volatility & 27.492 & 4.311 & 6.380 & 0.000 & 19.042 & 35.942 & \\
\hline Compounded returns & 0.150 & 0.061 & 2.450 & 0.014 & 0.030 & 0.270 & \\
\hline Constant & -0.568 & 0.199 & -2.860 & 0.004 & -0.957 & -0.178 & \\
\hline \multicolumn{8}{|l|}{ Number of OBS $=962$} \\
\hline \multicolumn{8}{|l|}{ LR $\operatorname{chi}^{2}(8)=291.85$} \\
\hline \multicolumn{8}{|l|}{ Prob $>\mathrm{chi}^{2}=0.000$} \\
\hline \multicolumn{8}{|c|}{ Log likelihood $=-387.7839$} \\
\hline \multicolumn{8}{|l|}{ Pseudo $R^{2}=0.2734$} \\
\hline \multicolumn{8}{|c|}{ Panel B: Marginal Effect at the Mean (dy/dx) } \\
\hline variable & $\mathrm{dy} / \mathrm{dx}$ & $\begin{array}{l}\text { Std. } \\
\text { Err. }\end{array}$ & $\mathrm{z}$ & $\mathrm{P}>\mathrm{z}$ & $\begin{array}{c} \\
95 \%\end{array}$ & C.I. ] & $\mathrm{X}$ \\
\hline INTERNAL* & 0.054 & 0.029 & 1.870 & 0.062 & -0.003 & 0.112 & 0.492 \\
\hline Leverage ratio & -0.782 & 0.078 & -9.990 & 0.000 & -0.935 & -0.628 & 0.349 \\
\hline ROA & -0.372 & 0.108 & -3.450 & 0.001 & -0.583 & -0.161 & 0.020 \\
\hline Financing Size & -0.516 & 0.141 & -3.660 & 0.000 & -0.792 & -0.240 & 0.099 \\
\hline Share turnover & 0.019 & 0.010 & 1.810 & 0.070 & -0.002 & 0.039 & 1.985 \\
\hline Number of analysts & -0.005 & 0.002 & -2.980 & 0.003 & -0.008 & -0.002 & 11.147 \\
\hline Return Volatility & 7.467 & 1.180 & 6.330 & 0.000 & 5.155 & 9.780 & 0.030 \\
\hline Compounded returns & 0.041 & 0.017 & 2.420 & 0.016 & 0.008 & 0.074 & 0.239 \\
\hline
\end{tabular}

$\left.{ }^{*}\right) \mathrm{dy} / \mathrm{dx}$ is for discrete change of dummy variable from 0 to 1 


\section{CHAPTER 3: DOES THE CFO APPOINTMENT AFFECT THE FIRM'S INFORMATION ENVIRONMENT?}

\subsection{Introduction}

The objective of this essay is to investigate the effect of Chief Financial Officer (CFO) appointments ${ }^{31}$ on the firm's information environment. The CFO assumes an important responsibility for overseeing the firm's financial system, including financial planning, budgeting, internal control, capital raising, tax management, and financial strategy (Mian, 2001). The CFO monitors a firm's financial reporting process, and therefore, holds key fiduciary responsibility for creating and disseminating accurate information about the firm's financial condition (Geiger and North, 2006). In this study, I answer the question of whether the CFO is considered as second-in-command and thus, if his/her replacement instigates market reaction. Or, are CFOs considered as a member of the executive team and his/her turnover is inconsequential? The reason I anticipate a market reaction following a $\mathrm{CFO}$ turnover is the personal legal obligation given to the $\mathrm{CFO}$ in the Sarbanes-Oxley Act (SOX) of $2002^{32}$. I limit my study to a firm's information environment due to the fact that the primary responsibility of the CFO toward the firm is both statutory and discretionary financial disclosure ${ }^{33}$. I use a longer period (+/- 365 days) to capture price

\footnotetext{
${ }^{31}$ I use "turnover," "replacement," "change," and "appointment" interchangeably.

${ }^{32}$ From section 302 of the Sarbanes-Oxley Act of 2002, "The Commission shall, by rule, require, for each company filing periodic reports under section 13(a) or 15(d) of the Securities Exchange Act of 1934 (15 U.S.C. $78 \mathrm{~m}, 78 \mathrm{o}(\mathrm{d}))$, that the principal executive officer or officers and the principal financial officer or officers, or persons performing similar functions, certify in each annual or quarterly report filed or submitted..." For the complete text please refer to: https://www.sec.gov/about/laws/soa2002.pdf.

${ }^{33}$ Warner et al. (1988) find that top management change (a change in the title of CEO, president or chairman of the board) is not a significant effect, however, Bonnier and Bruner (1989) argue that Warner et al. do not find any significant abnormal return surrounding top management change because they mix the distressed and sound firms together. Thus, for some firms top management change has (negative) information effect
} 
informativeness that is reflected in the firm's stock price due to a firm event such as CFO change. In addition, unlike previous research, my conclusion does not depend on a specific group sample. For example, Bonnier and Bruner (1989) and Mian (2001) use only CFOs removed by disciplinary actions and replacement of top management teams (does not include CFOs) of financially distressed firms respectively to test market reaction by abnormal returns. I posit that considering an analytical approach beyond the event study and utilizing a longer time horizon, I can capture the stock price informativeness due to an important event of a firm such as the replacement of CFOs. The perception of investors depends on the information environment in which the firm operates. In the short-run, markets can (over)react to any news and right afterwards can adjust for the overreaction. Therefore, two things are important: first, we must look beyond a short-term reaction (which can be a mere stimulus or noise), and second, we must employ tools, such as idiosyncratic variance and synchronous trading, to evaluate a holistic information environment. Even though a firm changes its CFO for the betterment of its stockholders, due to operating in an opaque information environment, the market may not perceive such "goodness" and consider it as a routine event.

Jiang et al. (2010) show that because CFOs have a greater role in financial reporting than CEOs, CFOs would be more prone to earnings management. They find that the magnitude of accruals and the likelihood of beating analysts' forecasts are more sensitive to CFO equity incentive than that of CEOs. Bertrand and Schoar (2003) show that "manager-specific effects matter both economically and statistically for the policy

and for some firms, the top management change has (positive) real effect. The final outcome is insignificant abnormal return. Bonnier and Bruner only consider the distressed firms for which market was expecting top management change and such change produces significant abnormal returns. 
decisions of firms (p. 1181)." Therefore, CFO turnover should be an important event for a firm and its stakeholders. Moreover, CFO replacement for a bad performing or distressed firm is even more important because the objective of such replacement is to ensure investors about the corrective actions by the management. Li et al. (2010) show that in the aftermath of adverse SOX 404 opinions by auditors, if the firm replaces its old CFO with a better qualified one, it receives clean opinions the following year. I analyze both situations: all firms together and only distressed firms.

Cools and Van-Praag (2007) show that the stock market values the scenario favorably when management of a firm replaces its top executive(s) with concurrent announcements of new hire(s) from outside. Mian (2001) shows that for poorly performing firms, replacement of the CFO from outside placates the upset investors. In addition, Bertrand and Schoar (2003) comment, “...one might argue that outside managers have 'stronger' or 'better' styles on average, as firms are willing to look outside their organization to find these managers (p. 1180)." Thus, identifying the turnover of CFOs and concurrent replacement from inside or outside should be reflected in the stock prices. Again, how well a firm's action has been perceived by the stock market investors depends on the information environment in which the firm operates.

The information environment of a firm is affected or determined by a few factors such as ownership structure (for example, if a firm has more block holders the information quality is better, Brockman and Yan, 2009), costs of obtaining information (Grossman and Stiglitz, 1980), and the number of analysts following the firm (Chan and Hameed, 2006). I use the variables that define the informativeness for each firm and analyze how the replacement of a $\mathrm{CFO}$ affects the informativeness reflected in the stock price. I avoid using 
event study methodology, which has traditionally been used to evaluate market reaction, due to events such as the replacement of top management teams, revolving door hiring policies, removal of the CFOs etc. Instead, I use the number of analysts following, analysts' forecast error, and analysts' forecast dispersion as measures to analyze firm information environment quality. The dispersion of analyst forecasts has been used in the literature to test analysts' information environment, uncertainty, and a firm's information risk (see Barron et al., 1998; Barron and Stuerke, 1998; Thomas, 2002; Johnson, 2004). Similar to Brockman and Yan (2009), I also use two other proxies for information environment quality. They are idiosyncratic volatility and stock return synchronicity (Morck et al., 2000). Thus, I used five information environment proxies: firm's idiosyncratic variances, synchronicity, number of analysts following, analysts' forecast error, and analysts' forecast dispersion. Furthermore, I divide the firms based on whether they hire fresh from outside (defined as external CFOs) or promote an internal candidate as a CFO (defined as internal $\mathrm{CFO})$.

At the univariate level, I find that synchronicity in stock trading increases (which indicates a higher information quality) significantly by a new CFO. The mean difference between the pre and the post appointments is 0.17 (t-value=3.26). Overall, internal CFOs improve the information environment more than external CFOs. Firms earning negative ROAs for the last three years or more can significantly improve information environment by hiring a new CFO. For example, firms earning negative returns for the last five years can improve in at least three proxies of information environment: idiosyncratic variances, number of analysts, and forecast dispersion. 
At the multivariate level, overall, there is no significant improvement in the information environment with a new CFO. However, firms earning negative ROAs for the last three or more years can improve information environment in some proxies: synchronicity, idiosyncratic variances, number of analysts, and forecast dispersion. This improvement in information environment is achieved from hiring an external CFO that is consistent with the finding in Mian (2001).

I contribute to the existing literature in a few aspects. First, after the SOX, the importance of the chief financial officer of a firm has grown significantly. One would expect stock market participants to evaluate the change of the CFO as an important event and adjust their expected payoffs accordingly. However, the reaction to such change depends on the firm's information environment. For example, a Fortune 500 company is followed by a large number of analysts34. When the CFO of such a company changes, a large group of investors are notified via a greater network of analysts. Whereas, analysts do not have incentives to follow smaller companies. Number of analysts is considered as a proxy for information environment quality (Chan and Hameed, 2006). I analyze the effects of CFO replacement on firm's information environment, which covers a broad spectrum of firm information quality, rather than identifying a short-term market over reaction that can evaporate fairly quickly.

Second, while other papers analyze CFO change in terms of short-term price reaction, I follow the long-term cross sectional difference-in-difference (DND)

\footnotetext{
${ }^{34}$ Bhushan (1989) argues that the payoff from the analyst's services from following a company is related to its size. For this reason, large companies are able to attract more analysts than small firms. Alford and Berger (1999) argue that analysts have incentives to follow firms with higher trading volumes.
} 
methodology to estimate the impact of CFO change on a firm's information environment. After Mian (2001), who has done a comprehensive analysis on firms' cumulative abnormal returns (CARs) surrounding CFO changes, there is a vacuum in the literature. My work fills this gap in the literature. Research on CFOs is important because the CFO plays an important role in creating a sound information environment for the firms. CFOs have discretion on how much information should be shared with outside sources in addition to statutory disclosure requirements. Finally, I use the established (taken from extant literature) tools of information environment to bypass any issue of omitted variable bias in the determination of a firm's information environment. I use five proxies ${ }^{35}$ to test the effect of CFO replacements on a firm's overall information environment. Three of the five proxies are related to the analysts who are a prime source of information with articulated profit reports and serve as an information gateway to the investors of a firm.

\subsection{Literature Review and Development of Hypotheses}

\subsubsection{Information Environment and CFO Change}

Information environment of a firm means: the all-inclusive process of generating, processing, disseminating, and using both accounting and non-accounting information. Fernandes and Ferreira (2008) define it as “...the extent to which stock prices incorporate firm-specific information in an accurately and timely manner (p. 216)." The higher the information precision the better the firm-specific informational environment. The firmspecific information quality can be improved by generating precise, accurate, and timely

\footnotetext{
${ }^{35}$ The reason I use five proxies is the CFO change is abstract. It is expected that over the long term the CFO change brings more profits and generates more cash for the firm. However, market is not always efficient and the effects from the CFO change may be missed by some measures but may be captured by some other measures.
} 
information at the firm level. In addition, choosing the correct channel of information and complying to a higher standard improves information precision. For example, Foucalt and Gehrig (2008), Fernandes and Ferreira (2008), and Herrmann et al. (2015) show that following cross listing, non-US firms enjoy better information environment due to stricter disclosure requirements and a higher number of analysts following them. Earlier research finds that via cross-listing non-US firms enjoy higher positive abnormal return, lower cost of capital, and higher Tobin's q ratio (see Miller, 1999; Errunza and Miller, 2000; Doidge et al., 2004). These findings are in support of the bonding hypothesis which states that cross-listing enables non-US firms with a listing on a US stock exchange to move from a poor environment to an improved environment. This environment is enhanced by the higher disclosure requirement, greater enforcement, and moderated litigation procedures (Fernandes and Ferreira, 2008; Coffee, 2002).

The Chief Financial Officer (CFO) has a key fiduciary responsibility of preparing the firm's financial statements and representing the true financial condition of the firm (Indjejikian and Matejka, 2009). The CFO has the expertise and independence to determine what number gets reported and whether earnings targets have been met or not (Mian, 2001; Geiger and North, 2006). Graham et al. (2005), from a survey of 400 CFOs, report that more than $90 \%$ of the CFOs opt for voluntary disclosure to earn a reputation for transparency or accuracy. More than $80 \%$ want to reduce the information asymmetry between the informed and uniformed investors. ${ }^{36}$ Statutory requirements for disclosure do not incorporate management's private information. Therefore, CFOs reduce the costs of

\footnotetext{
${ }^{36}$ Uninformed investors ask for a premium when they trade with informed investors (such as management or insider investors). Thus, the more skeptical they are about the stock price of a firm the more (information risk) premium they ask for.
} 
collecting firm-level information and attract more analysts to follow the firm with higher voluntary disclosure (Bhushan, 1989; Lang and Lundholm, 1996; Graham et al., 2005). Both a higher number of analysts following a firm and minimal costs of acquiring information contribute to the improvement of information precision. Moreover, Lobo and Zhou (2006) show an increase in conservatism in financial reporting subsequent to SOX. They find that firms report less accounting accruals and adjust losses quicker than the preSOX era. Li et al. (2010) find that when firms receive an adverse SOX 404 audit opinion, there is a spike in CFO turnover the following year and a more qualified CFO is hired to receive a clean opinion. Therefore, CFOs play an important role in a firm's financial reporting quality and consequently, impact the information environment of the firms.

The motivation of this research lies in the fact that CFOs independently play a role to ensure price informativeness of the firm's stocks by various means, such as voluntary disclosure, in addition to the statutory disclosure requirement, press release, newsletters, meeting with investors, and conference calls. Graham et al. (2005) report that CFOs do not establish a precedence of voluntary disclosure which they cannot maintain permanently. They comment, "Many interviewed CFOs state that reducing uncertainty about the firm's prospects is the most important motivation for making voluntary disclosure (p. 54)." The informational risk can be reduced by making the future earnings of the firm more predictive via discretionary disclosure (as markets hate negative surprises) (Graham et al., 2005). Moreover, Diamond and Verrecchia (1991) and Kim and Verrecchia (1994) suggest that voluntary disclosure reduces information asymmetry between informed and uninformed investors and thus, increases the liquidity of the firm's stock. 


\subsubsection{Information Environment Proxies}

Table 3.1 lists the proxies for information environment used in this essay. It is difficult to directly measure the information environment of a firm ${ }^{37}$. However, the listed proxies have been used by extant literature to gauge the firm's information environment.

\subsubsection{Testable Hypotheses}

Change of the chief financial officer (CFO) can be a significant event if investors were expecting such a change. Furtado and Rozeff (1987) show that investors' interest is well served by top management dismissal when they are already aware of the negative performance of the management. Therefore, I posit that:

Hypothesis 1: The replacement of the chief financial officer (CFO) affects firmspecific information environment.

The CFO successor announcement can either be concurrent, i.e., at the time of the dismissal announcement of the old CFO, or be subsequent. For the chief executive officer (CEO) the concurrent announcement of the successor is common (Cools and Van Praag, 2007). Furtado and Rozeff (1987) show that when top management dismissal announcement is contaminated with simultaneous successor announcement, the wealth effect is overestimated. Therefore, it is necessary to isolate the "pure" dismissal announcement from the dismissal with concurrent successor announcements.

The market response is mixed with regards to the CFO being appointed from either external or internal sources. Furtado and Rozeff (1987) argue that hiring the top executives from an external source signals unsuccessful human capital investment and it disappoints

\footnotetext{
${ }^{37}$ As pointed out by Fernandes and Ferreira (2008), "It is hard to test this relation (the relation between a firm's information environment and cross-listing) because we cannot directly measure a firm's information environment."
} 
the investors. In contrast, Mian (2001) shows that when CFOs are removed via disciplinary actions and replaced by internal hires, the market reacts in a significantly negative manner. Geiger and North (2006) find that when the CFO is replaced from outside, discretionary accruals reduce significantly, i.e. the newly appointed CFO shifts the blame to the outgoing CFO or makes a "clean slate." Their findings are dominated by external CFO appointments. Because the effect of the type of the CFO appointment on stock price informativeness is ambiguous, I test both propositions. I posit that:

Hypothesis 2A: The replacement of the chief financial officer (CFO) from the internal sources will have a significant effect on a firm's information environment

Hypothesis 2B: The replacement of the chief financial officer (CFO) from the external sources will have a significant effect on a firm's information environment

These hypotheses depend on critical definitions of "turnover," "external," and “internal." Denis and Denis (2005) argued that when they employed the management change definition by Warner et al. $(1988)^{38}$, they did not find any performance change surrounding the top management change. However, employing the definition of only forced departures, Denis and Denis (2005) find significant performance difference surrounding top management change. Therefore, I was cautious to follow Audit Analytics ${ }^{39}$ reasoning for defining "internal" and "external" appointments. I define internal appointments as a replacement of CFO by someone inside the organization who worked for the company at least one year. External appointments are defined new hires from

\footnotetext{
${ }^{38}$ Warner et al. (1988) include all type of management changes together such as "pursue other interests," "take a position outside the firm," "policy differences," and "no reason given" as forced turnover.

${ }^{39}$ See http://www.auditanalytics.com/
} 
outside without any form of relationship with the hiring firm. The detailed definitions are given in the data section.

\subsection{Data and Sample Selection}

I collected my data from Audit Analytics ${ }^{40}$ by reading $8-\mathrm{K}$ filings of the sample firms. Following accounting and finance literature in this area, I only consider firms that have total assets of 10 million or more at the end of the fiscal year during my sample period. Following accounting literature, I exclude utility and financial firms (SICCD=31, 44, 45, 46, and 47). A total of 2,764 firms experienced CFO change and meet the selection criteria in my sample period of 2005-2011. Some of the firms experienced multiple CFO replacement during the sample period. However, to keep the model estimation away from any sort of calculation bias, I consider each firm only once. Seventy-two percent $(1,997$ firms) of the 2,764 firms experienced at least one CFO replacement over the 2005-2011 period. To keep the effects of CFO replacement clean from any other management change, especially CEO change, I delete all the firms that experienced CEO change within three years surrounding the $\mathrm{CFO}$ change. For example, if a firm has experienced a $\mathrm{CFO}$ change in 2005, then it also experienced a CEO change either in 2004 or in 2006; I deleted that firm from my sample. I excluded any appointment in which the CFO has any sort of relation with the company prior to the appointment. For example, some CFOs worked as a consultant to the company for a short period of time, while some CFOs were in the audit team of the company.

\footnotetext{
${ }^{40}$ Please refer to: http://auditanalytics.com/
} 
I define the "announcement date" as the earlier date between the filing date and the effective date of the CFO appointment. I excluded CFO replacements with special cases such as CFO change due to retirement, death, corporate restructuring, and mergers and acquisitions. Moreover, I also excluded any "interim" CFO responsibility. For firms that experience multiple replacements, I take only the latest replacement. I divided CFO replacements into two classes: internal appointments and external appointments. I define an appointment as an internal if any of these reasons are mentioned for CFO change: (i) assuming additional Position(s), (ii) position Change within Company, and (iii) returning to Prior Position ${ }^{41}$. For external appointments, I read 8-k filings and determine that if it does not meet any of the aforementioned criteria for internal CFO, then the CFO is hired from outside. Companies that have insider holdings and institutional holdings of more than $100 \%$ are capped to $100 \%$.

I have used multiple data sources such as CRSP (Center for Research in Security Prices), COMPUSTAT, Audit Analytics, IBES (Institutional Brokers’ Estimate System), and Thompson Reuters. Matching the firms based on various IDs, I lost a few more observations. My final sample size is 1,599 (843 internal appointments and 756 external appointments). The number of observations across models are different due to: a) using a sub-set of full sample, b) using more variables into some model than others, and c) not all variables having the data for the same years. I mention the number of observations (NOBS) used in the models in the result tables.

${ }^{41}$ There are some other reasons mentioned such as mergers and acquisitions, corporate restructuring, and change in control. I excluded all these reasons. I made sure that my classification is accurate via contacting the Director of Research of Audit Analytics. He provided me with the same definition for internal and external appointments. 


\subsection{Methodology}

Studies like this traditionally use event study methodology in which a market model is used to estimate the systematic risk, or beta, in a bias-free estimation period. Then, the beta and mean standard error (MSE) are used to calculate cumulative abnormal returns surrounding the event. However, recent papers, such as Aktas et al. (2007) ${ }^{42}$ and Ahern (2009), ${ }^{43}$ show how event study methodology is seriously flawed. Aktas et al. (2007) show that when the estimation period is contaminated with unrelated events, standard OLS produces overestimated standard error of an individual firm's returns. They argued that the actual return generating process has two-stages: high variance regime and low variance regime, instead of one regime assumed by the traditional event study methodology. Aktas et al. (2007) comment, "This result offers a clear econometric foundation for the loss of power of classical event study methodology when the estimation window is contaminated by unrelated events (p. 132).” Ahern (2009) ${ }^{44}$ shows that when firms are grouped based on certain characteristics, such as market anomalies (for example, size or higher price-

\footnotetext{
${ }^{42}$ Aktas, N., DeBondt, E., Cousin, J-G. 2007. Event studies with a contaminated period. Journal of Corporate Finance, 13: 129-145.

${ }^{43}$ Ahern, K. R. 2009. Sample selection and event study estimation. Journal of Empirical Finance, 16: 466482 .

${ }^{44}$ Ahern (2009) shows that when a market model is used to generate the abnormal returns in which only independent variable is the market returns (NYSE or NASDAQ) rather than leaving other firm-characteristic variables behind, the methodology produces omitted variable bias which causes significant statistical errors. He comments: "It is incorrect to expect to observe the average market return on any given day because returns are positively skewed. This implies that the mean is larger than the mode in the distribution and that for more than half of a sample of randomly chosen days, the observed return will be less than the mean return. Because of the skewness, omitted variable bias will generate incorrect predictions on average even when the model allows for an endogenously determined intercept term. This bias will persist even in large samples. Thus, because biases in standard asset pricing models are generated by omitted variables, it makes sense to look at samples grouped by these characteristics."
} 
earnings ratios), or corporate events, event study methodology may produce erroneous conclusions. Therefore, I refrain from using a controversial short-time based event study. I use two year measures (one year before and one year after) surrounding the CFO appointments. The reasons for utilizing long-term tools are manifold. First, a new CFO who changes the reporting system of the firm, can create more disclosure for the investors, and thus, add to new channels of information. Second, a new CFO also brings change to the firm's operation by spinning off or divesting some of the subsidiaries and/or expanding and investing into new businesses. All these changes would not be visible in the short-term window surrounding the change. The real effect of such change needs more time (at least one year as I argue) to be reflected onto stock prices (or on tools of the information environment). Third, information environment takes into account all possible channels of generating, using, and disseminating information about a particular firm. While other studies depend on stock prices (assuming the market is efficient and thus, the sole determinant of future cash flows), information environment talks about the "information set" (as usually denoted by $\Omega$ ) on which stock price depends on. Thus, information environment takes into account the greater (and more comprehensive) "input systems" of stock price.

In addition, I argue that information environment quality-shift would be significantly different for two such types of appointments: interval hires via promotion versus hires from external sources. The "timing" of the CFO appointment is important. For example, a firm which is doing well for several years may not feel the need to change its CFO as urgently as a firm that has been performing poorly for the recent times. Thus, the "internal vs. external" and "stressed vs. sound" dynamics are important for firms going into 
external labor markets and finding a new $\mathrm{CFO}$ which is time consuming and costly. Firms search the external labor market when the investors are expecting a replacement from outside. Figure 1 provides an overview of my research design.

To test hypothesis \#1, I use the difference-in-difference (DND) approach to separate the effect of CFO change on the firm's information environment. The following specification is used to test the effect of CFO change:

$Y_{i t}=\alpha+\beta_{1}$ Post $+\beta_{2}$ Treatment $+\beta_{3}($ Post $*$ Treatment $)+\varepsilon_{i t}$

Where, $Y_{i t}$ represents a firm's information environment proxies: idiosyncratic variances, synchronicity, number of analysts, analysts' forecast error, and analysts' forecast dispersion; $i$ is for firm $i$ and $t=$ time ( $t=1$ for post appointment and 0 for preappointment period).

Here, $\beta_{3}$ is our interest, and it is determined as follows:

$E\left(Y_{i 1} \mid\right.$ Treatment $\left.=1\right)-E\left(Y_{i 0} \mid\right.$ Treatment $\left.=1\right)=\left(\alpha+\beta_{1}+\beta_{2}+\beta_{3}\right)-\left(\alpha+\beta_{2}\right)=$ $\beta_{1}+\beta_{3}$

$E\left(Y_{i 1} \mid\right.$ Treatment $\left.=0\right)-E\left(Y_{i 0} \mid\right.$ Treatment $\left.=0\right)=\left(\alpha+\beta_{1}\right)-\alpha=\beta_{1}$

The DND is equation (2) minus equation (3):

$E\left(Y_{i 1} \mid\right.$ Treatment $\left.=1\right)-E\left(Y_{i 0} \mid\right.$ Treatment $\left.=1\right)-\left[E\left(Y_{i 1} \mid\right.\right.$ Treatment $\left.=0\right)-$
$E\left(Y_{i 0} \mid\right.$ Treatment $\left.\left.=0\right)\right]=\beta_{3}$

I use firm-specific controls that may affect firm's information environment in equation (1). I use insider holdings, institutional holdings, natural log of market value, 
ROA, and standard deviation of ROA. The definitions of the control variables are given in the appendix.

In choosing the control group (treatment $=0$ in the above specifications), I use two filtering processes: first, I identify firms in the same industry and similar size as the treatment firms. Second, I use propensity score-matched to identify the control sample. The two-step filtering process makes the process robust and produces unbiased statistical estimates $^{45}$. Because I have collected data from several sources, I have to exclude those firms that do not have data for all the variables. In some cases, the number of control firms is lower than the treatment firms. I use the bootstrapping method to find the best group of controls. In this case, I randomly pick the number of control firms with replacement. Thus, each firm has the same probability to be included in the control. This method makes the controls free from any estimation bias and statistically accurate. I winsorize all the variables at the $1^{\text {st }}$ and $99^{\text {th }}$ percentile.

Moreover, similar to Mian (2001), I separate the samples into $-5,-4,-3,-2$ and -1 year, which means sample firms experiencing negative industry adjusted ROA for the last five years, four years, three years, two years, and one year prior to CFO replacement, respectively. Industry adjusted ROA is calculated as the firm's annual ROA minus the median ROA in the industry in which the firm belongs. In the first stage, I run logit regression in which distressed (value is 1 or 0 ) is the dependent variable and insider holdings, institutional holdings, market value, operating profit, and operating risk are

\footnotetext{
${ }^{45}$ For a comprehensive discussion on traditional matching, such as same SIC and asset size and propensity based matching, please refer to "Chief Executive Officer Equity Incentives and Accounting Irregularities" by Armstrong et al. (2010), Journal of Accounting Research, Vol 48.
} 
independent variables. The logit regression was estimated using maximum likelihood estimation (MLE). In the second stage, equation (1) is run with other control variables in a paired sample setting. The same number of firms that experience CFO change and nonCFO-change firms are put together based on their propensity scores given by the logit estimation at the first stage. I create fictitious CFO change dates for the firms (control group) that did not experience CFO change. Matching of the firms is based on the firststage filtering process mentioned earlier.

To test hypothesis \#2 (A\&B), I use a similar specification as equation (1). Here, the model is run as a subset of equation (1) as I want to test whether internal or external CFO appointment matters more for the firms that experienced CFO replacements. Thus, the specifications have become as follows:

$$
\begin{aligned}
& Y_{i t}=\alpha+\beta_{1} \text { Post }+\beta_{2} \text { INTERNAL }+\beta_{3}(\text { Post } * \text { INTERNAL })+\varepsilon_{i t} \\
& Y_{i t}=\alpha+\beta_{1} \text { Post }+\beta_{2} \text { EXTERNAL }+\beta_{3}(\text { Post } * \text { EXTERNAL })+\varepsilon_{i t}
\end{aligned}
$$

The results from equation (5) and (6) will be very similar, i.e., all the coefficients will have the same value with opposite signs and only the intercept will be different. Because in equation (5), INTERNAL is testing the effect from 0 to 1 , in equation (6) it is just the opposite, from 1 to 0 .

Similar to Mian (2001), who associates the external appointment with the firm's negative performance, I separate the samples into $-5,-4,-3,-2$ and -1 year, which means sample firms have been experiencing negative industry adjusted ROA for the last five years, four years, three years, two years, and one year prior to CFO change, respectively. This group of firms will be a sub-sample of the firms used in earlier specification (refer to 
equation \#4) and conditional on the output whether CFO change matters for firms. To test the effect for CFO change in a distressed firm, I add an indicator variable for distressed firms to equation (6) that takes a value of 1 , if the firm is distressed and 0 , otherwise ${ }^{46}$. The specification takes the following form:

$Y_{i t}=\alpha+\beta_{1}$ Post $+\beta_{2}$ EXTERNAL $+\beta_{3}($ Post $*$ EXTERNAL $)+\beta_{4}$ Distressed $+\varepsilon_{i t}(7)$

I had to add the variable distressed even after separating the sample based on negative operating profit in order to create paired samples from the non-distressed class. In the first stage, I run logit regression in which distressed (value is 1 or 0 ) is the dependent variable and insider holdings, institutional holdings, market value, operating profit, and operating risk are independent variables. The logit regression was estimated using maximum likelihood estimation (MLE). In the second stage, equation (6) is run with other control variables in a paired sample setting. The same number of good and distressed firms are put together based on their propensity scores given by the logit estimation at the first stage.

In order to make sure that my hypothesis testing is robust and free from type II error, I run power of the test for the models. Type II error or $\beta$ error is falsely accepting an incorrect null hypothesis $\left(\mathrm{H}_{0}\right) .1-\beta$ indicates the power of the test which depends on three parameters: level of significance, sample size, and size effect. I use G*Power-3 program ${ }^{47}$ by Faul et al. (2007) to compute the statistical power of the hypotheses. Post hoc power analyses (Cohen 1988) is used as "type" in the computation.

\footnotetext{
${ }^{46}$ For example, if a firm is experiencing negative industry adjusted ROAs for the last five years before the CFO replacement, then "Distressed" equals 1, otherwise 0.

${ }^{47}$ Available at http://www.gpower.hhu.de/
} 


\subsection{Results}

Table 3.2 reports descriptive statistics of information environment variables used in the study. In Panel A, I divide all five dependent variables into pre and post appointment. The results are mixed. Synchronicity and number of analysts increased during the postCFO replacement era which indicates a stronger or better information environment. However, idiosyncratic variances and analysts' forecast errors and dispersion slightly increased after CFO replacement. All the information environment variables indicate a poorer state after the CFO replacement except synchronicity ${ }^{48}$ and number of analysts. A conclusive decision cannot be made about the status of the firm's information environment from stock price informativeness variables. This phenomenon goes against the intuition. It may be the case that the negative effect of $\mathrm{CFO}$ change for some firms cancels the positive effect for some other firms. To isolate the type of effect, it is necessary to group firms based on some financial features. One such feature can be operating profit. Mian (2001) used industry adjusted operating profits, in addition to market reaction, to estimate the impact of CFO change and concludes that $\mathrm{CFO}$ replacement is preceded by a decline in operating performance. In the next section, I separate the distressed firms and compare these firms with similar firms (matched by first, same SIC, and asset size, and second, by propensity score matching) to test the significance of CFO replacement. Intuitively, for good performing firms, changing $\mathrm{CFO}$ may be considered by the market as a routine phenomenon. However, for the distressed firms, the CFO replacement can be a big leap. I divide the distressed firms sample into five groups: firms that are producing industry

\footnotetext{
48 Synchronicity is still negative, however, less negative than the pre-scenario. That is how it is a positive change $[=0.862-(-0.689)]$.
} 
adjusted negative operating profits for the last five years, for four years, and so on until the year before the $\mathrm{CFO}$ replacement.

In Panel B of Table 3.2, I divide all the variables (both dependent and independent variables) into two groups based on the appointment types: internal appointments which is defined as a promotion to a CFO, and external appointments which is defined as a hire from outside the organization. The results are mixed: idiosyncratic variances are lower, and synchronicity and number of analysts are higher for internal appointment. This scenario means good information environment for internal appointments. Both analysts' forecast errors and forecast dispersion is higher in internal appointment, which indicates poor information environment. In this case, I cannot conclusively say that internal appointment is better. Mian (2001) finds that external CFO appointment is associated with weaker operating performance. Among the independent variables, internal appointments are related with bigger firms and reduce the operating risk of the firms.

Table 3.3 represents the $t$-test between treatment (CFO change) and the control group firm. None of the information environment variables are significant between treatment group and control group except forecast dispersion (significant at the 10\% level). The situation is similar for the independent variables. Therefore, I decided to group the firms based on their industry adjusted profit. A firm is considered distressed ${ }^{49}$ if it earns negative return relative to the industry in which it operates. Similar to Mian (2001), I divided distressed firms into five groups: firms earning negative returns for the last five years, four years, three years, two years, and one year before the CFO change. I find a

\footnotetext{
49 In this case, the firm's annual industry adjusted ROA is negative, i.e., $A D J R O A_{i t}=R O A_{i t}-$ $\left[\operatorname{MEDIAN}\left(R O A_{S I C, t}\right)\right]<0$
} 
significant difference between the treatment group and control group. For example, the number of analysts is $6.31(=\mathrm{EXP}(1.814))$ for treatment group and 4.53 (=EXP(1.510)) for the control group. In addition, analysts' forecast error or forecast dispersion is statistically significant between treatment group and control group surrounding the years of CFO change. For firms that are distressed for the last four years, I did not find any significant information environment variable. I only report statistically significant values in the distressed sample (see lower part of Table 3). From now on, I will be focusing on both situations: all firms (sound and distressed) and only distressed firms.

Table 3.4 outlines the expected signs for the multivariate analysis. Generally speaking, a positive sign indicates a better information situation, while a negative sign indicates a worse environment unless otherwise specified. A better information eco-system should have less noise, higher synchronous trading, presence of a large number of analysts, ${ }^{50}$ and less difference in opinion among the analysts. I should have positive signs for synchronicity and number of analysts and negative signs for idiosyncratic variance, analysts' forecast error, and dispersion.

Panel B of Table 3.4 lists the expected signs for the independent variables used in the multivariate setting under the five dependent variables (proxies for the firm's information environment). The natural log of number of analysts is used both as a dependent variable and as an independent variable. Under the first two cases: idiosyncratic variance and synchronicity, it is used as one of the independent variables. Previous literature has used this type of setting (e.g. Chan, (year); Hameed, (year); Brockman, and

\footnotetext{
${ }^{50}$ In this paper, I am assuming a higher number of analysts is tantamount to a quality information system. Even though a small group of analysts may produce quality forecasts, I am not going into that direction, and it is beyond the scope of this paper.
} 
Yan, 2009) with IDV and synchronicity. The relation between ROA and number of analysts is ambiguous. For a growing firm, ROA could be lower due to heavy investment into assets at the earlier years; however, the firm might be followed by a large number of analysts. This is especially true for firms in the IT industry. A similar ambiguity arises in the case of operational risk (SD of ROA). Therefore, a caution has to be exercised in explaining the effect of these two independent variables.

Table 3.5 includes the estimation results of hypothesis 1, "The replacement of the chief financial officer (CFO) affects firm-specific information environment," using equation 1 with the control variables. Control variables are selected based on the previous literature on information environment. In this specification, I have put all the firms, sound and distressed, in a paired sample setting $(\mathrm{N}=1599 * 2=3,198$ in total $)$. The variable of interest, post*treatment, is not significant in any of the information environment variables. The possible reason could be that mixing sound and distressed firms together offsets any effects that may exist, which is consistent with the univariate analysis done before. In the next section, I shall divide the firms into groups with one year increments: being distressed for the last 5 years until 1 year prior to the CFO replacement as I did in the univariate analysis.

Consistent with Brockman and Yan (2009) and Chan and Hameed (2005), I also find that the natural log of the number of analysts, insider holdings, institutional holdings, the natural log of market capitalization, operating profits, and operating risk are significant determinants of firm-specific information environment. Even though the sign of institutional holding is not consistent with Brockman and Yan (2009), it is consistent as per my specification. For example, institutional holdings increase synchronicity and the 
number of analysts, however, reduces idiosyncratic volatility, and analysts' forecasts dispersion. My findings are also consistent with the extant literature. Fernandes and Ferreira (2008) find that synchronicity (a proxy for information environment in their paper) increases in good information environments. Chan and Hammed (2005) find that the higher number of analysts incorporates greater market-wide information and lesser firm-specific information.

In order to better understand the sign change, I compare block institutional holdings ${ }^{51}$ used by Brockman and Yan (2009) for the same group of firms used in my sample. Figure 3.2 shows a complete shift in the institutional holding from 1996-2001 in 2005-2011. The mean and median shareholding by outside block holders were $15.99 \%$ and $14.12 \%$, respectively, with a standard deviation of $13.78 \%$ in 1996-2001. However, for the same group of firms, the mean and median are $78.51 \%$ and $83.13 \%$, respectively, with a standard deviation of $18.86 \%$ in $2005-2011$.

Therefore, it is reasonable to argue that the shift in the nature of institutional holdings also shifts the behavior of the stock market, because nowadays, the majority of trades are done by institutions who are better equipped with less costly and more accurate information than some diffuse retail investors. Institutional trading reduces (increases) idiosyncratic volatility (synchronicity), which makes sense because institutional investors trade based on information. Avramov, Chordia, and Goyal (2006) show that noninformational liquidity driven (or herding) investors' trades increase market volatility,

\footnotetext{
${ }^{51}$ Block holding data are available only for the 1996-2001 period in Wharton database. Brockman et al. (2009) used the same time frame in their study.
} 
following stock price declines, whereas informed (or contrarian) investors' trades reduce market volatility, following stock price increases.

In Table 3.6, I find that the replacement of the CFO brings significant change for firms that are suffering for longer periods of time, such as the last 5 years, in reducing idiosyncratic variances and forecast error. Idiosyncratic variance reduces by 0.019 (significant at the 5\% level) units when firms replace their CFOs. In addition, analysts' forecast errors reduces by 0.508 (significant at the $1 \%$ ) level when distressed firms replace their CFOs. Synchronicity, the natural log of the number of analysts and forecast dispersion is not significant. Out of five variables, two information environment variables show significance. The independent variables are in line with the expected signs outlined in Table 4. For example, the presence of analysts decreases idiosyncratic variance or noise in the market. The presence of about three $(2.72=\mathrm{EXP}(1))$ analysts reduces 0.008 weekly idiosyncratic variance. Moreover, bigger firms produce higher synchronicity and attract a large number of analysts. The natural log of market capitalization increases both synchronous trading in the market and the natural log of the number of analysts (both of the variables are significant at $1 \%$ level). Because, both the market capitalization (right hand side variable) and number of analysts (left hand side variable) are in log format, I can explain the effect as a $1 \%$ increase in the market capitalization, which will increase the chance of being followed by one more analyst by $0.42 \%$.

Table 3.7 includes the effect of CFO replacement for firms that are suffering for the last four years prior to CFO replacement. Out of five variables, only one information environment variable shows significance (at $10 \%$ level) due to the $\mathrm{CFO}$ change. 
Insider holdings significantly reduce the forecast errors and hence, contribute positively to the firm's information environment. Institutional holdings remain a strong element for improving a firm's suffering information environment. For example, in four out of the five parameters of information environment quality, institutional holdings are significant. It reduces idiosyncratic variance and analysts forecast dispersion and improves (attracts) synchronicity (analysts). Large firms improve a firm's information environment (the natural $\log$ of the market value is significantly positive at $1 \%$ level under synchronicity) and attract a large number of analysts (the natural log of the market value is statistically positive at $1 \%$ level under the natural $\log$ of the number of analysts). All other independent variables are in line with the expected signs outlined in Table 4.

Table 3.8 produces the estimation results for firms that are suffering operationally for the last three years. The interaction variable, post*treatment is significant at the $10 \%$ level and $1 \%$ level under synchronicity and the natural $\log$ of the number of analysts, respectively. In both cases, replacing the CFO improves synchronicity by 0.212 and attracts $1.25(=\mathrm{EXP}(0.221))$ analysts. Even though idiosyncratic variances and analysts' forecast errors have the correct sign, they are not significant. Analysts' forecast dispersion is neither significant nor does it have the correct sign. Both the institutional holdings and market capitalization remain strong determinants of the firm's information environment.

Table 3.9 and 3.10 report the extent of information environment improvement in post-CFO turnover for firms that earn negative industry ROA for the last two years and for the prior year of CFO change, respectively. CFO turnover for firms that earn negative ROA for the two years prior does not improve the information environment of those firms. Firms should allow CFOs to improve the performance for at least two years before 
replacing them. It can be seen from the above discussion that firms benefit from replacing a CFO who has produced negative earnings for the last consecutive three or more years.

Table 3.11 reports the estimation results of hypothesis $2 \mathrm{~A}$, "The replacement of the chieffinancial officer (CFO) from internal sources will have a significant effect on a firm's information environment". In this table, I include all the firms that have CFO change and based on the definition provided in the data section, I divide the CFOs into internal and external. If, according to the hypothesis, incumbents promoted to CFOs have a significant impact on a firm's information environment, the interaction term (internal CFO*post) should be significant. However, the interaction term is not significant under any of the models. Institutional holding is a significant determinant of a firm's information environment as it is significant with the correct signs under four out of five measures. For big firms, information is easy to access. Coefficients for ln of market capitalization show this phenomenon. For example, idiosyncratic variances, analysts' forecast errors, and analysts' dispersions reduce significantly, whereas synchronicity and number of analysts following firms have increased significantly.

Table 3.12 reports the estimation results of hypothesis $2 \mathrm{~B}$, "The replacement of the chief financial officer (CFO) from external sources will have a significant effect on the firm's information environment". Like the previous results (in reference to Table 3.6), the interaction term (=External CFO*post) captures the post effect of external CFO turnover on the firm's information environment. Neither internal nor external CFO turnover affects the firm's informativeness under the current specification.

Insider holdings and institutional holdings are significant determinants of the information environment. Although institutional holdings were significant at the earlier 
specification, insider holdings were weaker in the current setting. Intuitively, this makes sense because insiders know whether an incumbent would be a better CFO, and if not, they go for a new hire. The natural log of market capitalization is significant (four of them significant at the $1 \%$ level and one at the $10 \%$ level) in all five models with the correct sign. Big companies increase the synchronicity, attract more analysts to follow those firms (Alford and Berger 1999), and decrease idiosyncratic variance, analysts' forecast errors, and dispersion. Like before, I split the sample into sound and distressed firms based on their operating profits for the last five years. I use the same specification as used in Table 9 and 10, however, with an additional variable, distressed, which is an indicator variable that takes a value of 1 for being a distressed firm and 0 for sound firms. I need this variable to capture the effect of being distressed in a pool of sound and distressed firms. As seen in Table 9, placing all sound and distressed firms together is not a suitable idea to extract the effect of CFO replacement on a firm's information environment.

Table 3.13 includes the results for the firms that earn negative industry operating profits for the last five years (-5 years). I expected the CFOs hiring from outside of the firms with fresh knowledge to the status-quo of the firm's operation would significantly change the firm's information environment. Intuitively, for firms that are suffering for five years, an internal $\mathrm{CFO}$ cannot do much to earn a positive profit, therefore, a new $\mathrm{CFO}$ can bring the expected change. The overall market does not adjust their expectations after the CFO change because the interaction term, post ${ }^{*}$ external, is not significant for idiosyncratic variance and synchronicity. The appointment of an external CFO significantly (at the 5\% level) reduces the analysts' forecast errors by 0.371 units. My results are consistent with 
that of $\operatorname{Mian}^{52}$ (2001) who finds that for poorly performing firms, replacement of the CFO from outside placates upset investors in the shorter term (using event window of -1 to 0 day), however, over the longer term, such as -250 to -2 days or -500 to -2 days, investors do not care (insignificant CARs). I anticipated that after the Sarbanes-Oxley Act of 2002, the investor reaction behavior might have changed with regards to CFO replacement. In the pre-SOX era, the CFOs were not as important as they are in the post-SOX ${ }^{53}$ era.

Table 3.14 reports findings for the firms that are distressed for four years before they replace their CFOs. Being a distressed firm increases noise and decreases synchronicity in the market, distressed is significant at 5\% under IDV and is significant at $1 \%$ under synchronicity. When those firms replace their CFOs, only synchronicity (a proxy for the firm's information environment) responds to such an event (significant at 10\% level). All other information environment variables are non-responsive to the CFO change. Institutional holdings and market capitalization are strongly significant (most of them 1\% level) throughout all the models.

Table 3.15 reports the results of distressed firms that earned negative industry adjusted ROA for the last three consecutive years. For firms that earn negative returns for the last three years, CFOs hired from external sources would improve the information environment of the firms. Both number of analysts and their earnings forecast errors are impacted by the external CFO hires. For example, five $(=\mathrm{EXP}(1.61))$ more analysts start

\footnotetext{
${ }^{52}$ Mian (2001) data covers 1984-1997.

${ }^{53}$ For this reason, there are only a handful of studies on CFO replacement or turnover in the pre-SOX period as opposed to CEO, President or Chairman. Mian (2001) does an anatomy of CFO replacement; Aier et al. (2005) and Geiger and North (2006) investigate the relation between accounting restatement and CFO turnover. However, their data are pre-SOX as well-Aier et al. 1997-2002 and Geiger and North 1994-2000.
} 
following a firm after it replaced its CFO from external sources. Also, 0.32 units of an earnings forecast error is reduced from an external CFO appointments vis-à-vis internal appointment.

From earlier results (refer to Table 3.9 and Table 3.10), it is seen that CFO change (including both types, internal and external) does not matter for firms earning negative returns for the last two years. CFO change only matters for firms that earn negative ROAs for the last five, four, and three years. External CFO effects are conditional on overall CFO change. Therefore, I only show external CFO effect on firm information environment for $5,-4$ and -3 years.

\subsection{Conclusion}

Under Section-302 of the Sarbanes-Oxley Act 2002, both the CEO and CFO are held personally accountable for the integrity of a firm's financial statements and particularly, its earnings. The CFO of a firm takes responsibility for the financial running of a firm. Moreover, CFOs are ideal candidates for future CEOs (see Matsunaga et al., 2008). Therefore, it is natural to expect that when there is a CFO replacement (either from an internal or external source), a market repercussion happens. To the best of my knowledge, there is no research available which discusses how category (internal vs. external) of CFO appointments affects firm-specific information environment quality. The contribution of this study is new in that I explore a dimension of research, which analyzes a firm's information environment and market response to an important firm-specific event - CFO change. A comprehensive study on CFO replacement was first done by Mian (2001) based on the data of 2,227 sample firms in 1984-1997. Almost all the papers in 
economics, accounting, and management literature talk about the replacement effects of CEOs, chairmen, presidents, COOs (chief operating officer) etc.

My study ties an important firm-event with the information environment in which the firms are operating. I use established tools that are used by extant research to define the improvement in stock price informativeness. I posit that the long-term tool, information environment, effectively captures the overall market reaction (or adjustment) toward the CFO replacement better than short-term tool, event study. There is no significant difference between pre and post replacement in events nearest to the quarterly analysts' forecast dispersion surrounding the CFO replacement. In some instances, I find significant market behavior change for pre and post CFO replacement when tools, such as idiosyncratic volatility (using daily stock price data), synchronous trading behavior, the number of analysts' following a firm over a year, and +/-180 day analysts' absolute forecast errors, are applied. However, the results are not consistent and I cannot conclusively say that CFO change impacts a firm's information environment.

My findings are robust because I use two filters in choosing the right group of firms and use propensity score matching to match the similar firms but without $\mathrm{CFO}$ change. In addition, I use five established measures of information environment variables. I was unable to measure the informativeness, which is consistently a significant determinant of information environment across all the models. In a few specifications, I find at least one or two information environment variable(s). However, none of them are consistent over all the models. The information environment of a firm incorporates the eco-system of information. The environment can be affected by both the external mechanism and internal mechanism of firms. For example, the proposed Silicon Valley based idea of Long-Term 
Stock Exchange ${ }^{54}$ (LTSE) can change the whole dynamics of evaluating firms or executives based on the short term milestones such as quarterly or annual performances. Because, LTSE will be built on an incentive structure that will focus on the long-term goals rather than short-term metrics. The $\mathrm{CFO}$ alone may not be able to bring the change in it in a short period of time. The possible extension of this research could be to include more executives and board members. In addition, a time series study may be able to catch the change in the firm information environment.

${ }^{54}$ For more information, please refer to: http://www.bloomberg.com/news/articles/2016-06-12/siliconvalley-s-audacious-plan-to-create-a-new-stock-exchange 
Figure 3.1 Research Design

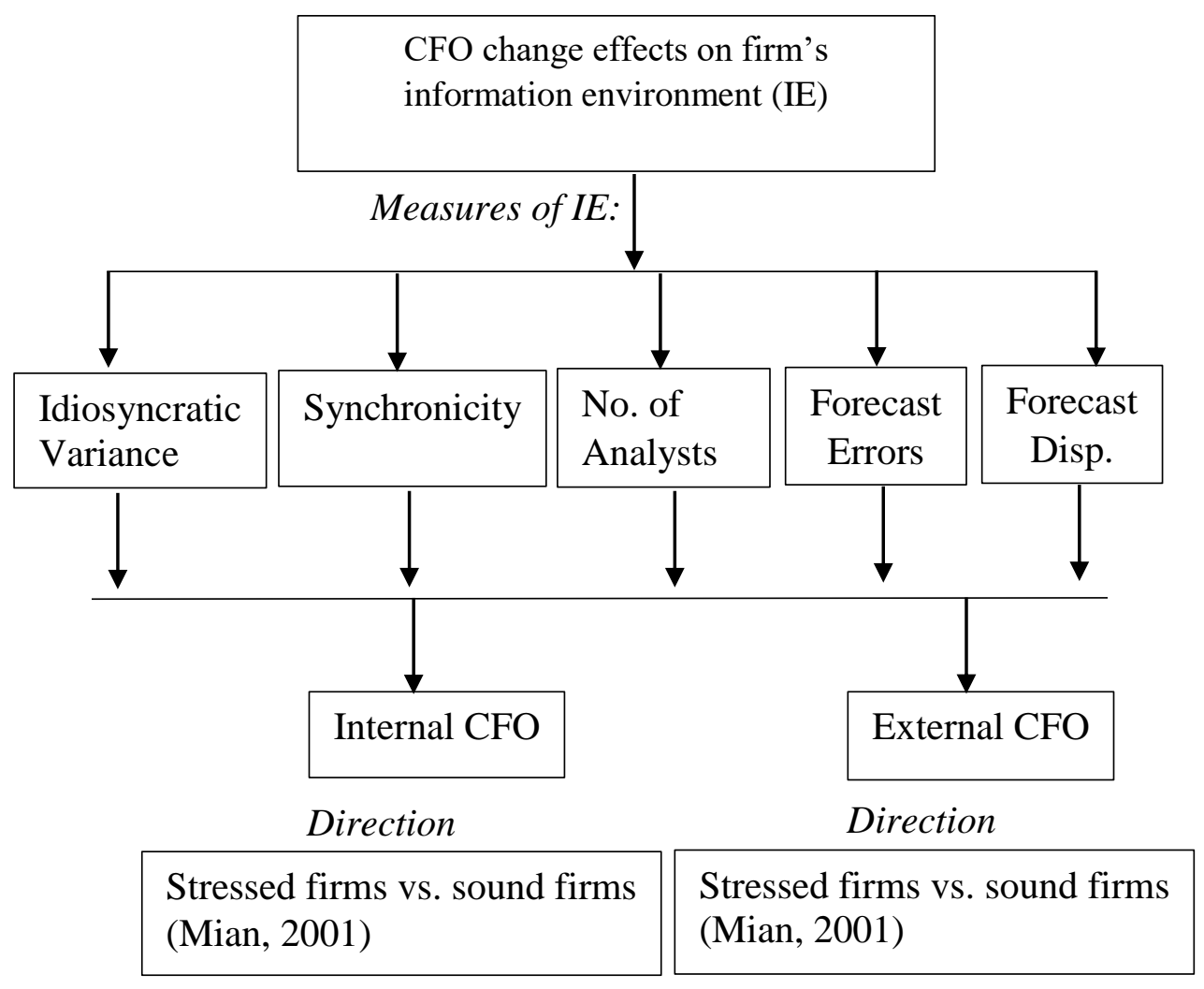


Figure 3.2 Comparison between institutional holding (block holding by outsiders) of a group of firms in 1996-2001 with institutional holding of the same group of firms in 2005-2011

The left panel shows the distribution of institutional block holding data used by Brockman et al. (2009) for 437 firms matched with my sample. Comparing with the right panel of my sample, we can see that the distribution has shifted completely. During Brockman's et al. (2009) sample period, the distribution was right skewed with mean $=14.12 \%$, whereas, in my sample period it is left skewed with mean $=78.51 \%$.
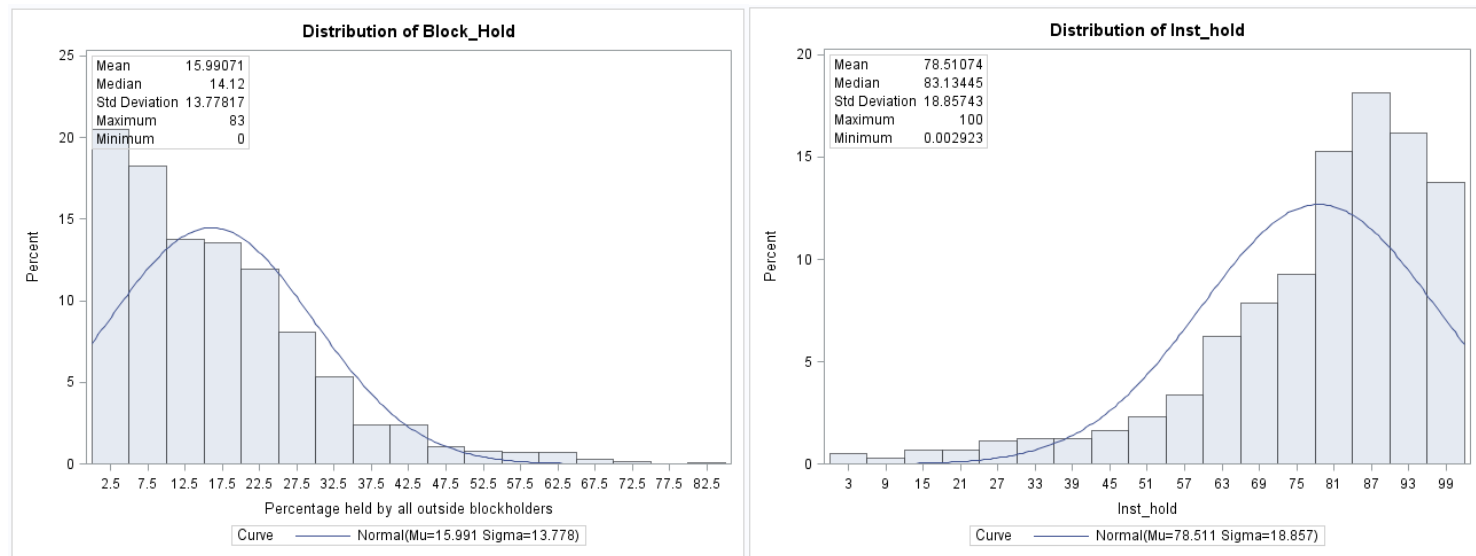
Table 3.1 Definition of Information Environment Variables

\begin{tabular}{|c|c|c|}
\hline nent Proxy & Related Literature & Relationship \\
\hline $\begin{array}{l}\text { Idiosyncratic variance }(I D V) \text { : it captures the firm- } \\
\text { specific component in stock price, i.e., the relative } \\
\text { price impact which is not captured by market and } \\
\text { industry return. Thus, it is the degree to which firm- } \\
\text { specific information is impounded into stock price } \\
\text { (Brockman and Yan 2009). Following Brockman and } \\
\text { Yan (2009), to calculate idiosyncratic volatility (IDV), } \\
\text { I estimate the following regression using weekly } \\
\text { contemporaneous and lagged market and industry } \\
\text { returns as independent variables for each firm for one- } \\
\text { year time period (both for pre- and post- } \\
\text { announcement): } \\
R_{i, t}=\beta_{0}+\beta_{1} M k t R_{i, t}+\beta_{2} M k t R_{i, t-1}+\beta_{1} I n d R_{i, t}+ \\
\beta_{1} I n d R_{i, t-1}+\varepsilon_{i, t} \\
\text { Idiosyncratic volatility is the standard deviation of the } \\
\text { residuals of the above regression. }\end{array}$ & $\begin{array}{l}\text { Fernandes and } \\
\text { Ferreira (2008), } \\
\text { and Brockman and } \\
\text { Yan (2009) }\end{array}$ & $\begin{array}{l}\text { Higher IDV means more noise in the market. } \\
\text { A well designed portfolio (i.e., investing in } \\
\text { stocks that have negative correlations) can } \\
\text { significantly reduce the IDV. Gul et al. } \\
\text { (2011) argue that more information into } \\
\text { public reporting crowds out private } \\
\text { information. Moreover, public reporting is } \\
\text { less frequent and has less impact on daily } \\
\text { returns than private information, thus, it } \\
\text { reduces firm-specific variance. Therefore, } \\
\text { higher quality of earnings should increase } \\
\text { public information and decrease private } \\
\text { information (Gul et al. 2011). In my case, } \\
\text { lower IDV (or noise) means higher } \\
\text { information environment quality. }\end{array}$ \\
\hline
\end{tabular}




\begin{tabular}{|c|c|c|}
\hline $\begin{array}{l}\text { Synchronicity (SYNCITY): Invented by Morck et al. } \\
\text { (2000) in studying synchronous movement of stock } \\
\text { returns in emerging economies. The firm level weekly } \\
\text { return is regressed on market and industry return (the } \\
\text { same equation in the case of IDV). The higher the } \mathrm{R}^{2} \\
\text { the higher the synchronicity meaning that individual } \\
\text { stock returns are highly correlated with the stock } \\
\text { market. Piotroski and Roulstone (2004) and Brockman } \\
\text { and Yan added industry return, lagged industry return, } \\
\text { and lagged market return to the original regression. } \\
\text { Finally, it is scaled as following so that it can take } \\
\text { negative values and can be used in statistical tests that } \\
\text { depend on normality assumption: } \\
\qquad S Y N C I T Y_{i, t}=\log \left(\frac{R^{2}}{1-R^{2}}\right)\end{array}$ & $\begin{array}{l}\text { Morck et al. } \\
\text { (2000), Piotroski } \\
\text { and Roulstone } \\
\text { (2004), Chan and } \\
\text { Hameed (2006), } \\
\text { Brockman and Yan } \\
(2009)\end{array}$ & $\begin{array}{l}\text { In the case of emerging economies, Morck et } \\
\text { al. (2000) find higher synchronous trading of } \\
\text { stocks. Moreover, they also show that in the } \\
\text { US stock market synchronicity reduced over } \\
\text { time. However, in the last year of their } \\
\text { sample period (in 1995) about } 60 \% \text { of the } \\
\text { stocks moved together. Chan and Hameed } \\
\text { (2006) find that the presence of security } \\
\text { analysts lessen the firm-specific noise. They } \\
\text { argue that if firm-specific price movements } \\
\text { reflect noise then the presence of security } \\
\text { analysts reduces the noise and consequently } \\
\text { increases the synchronicity (higher number } \\
\text { of analysts is positively related with } \\
\text { synchronicity). Therefore, higher } \\
\text { synchronicity means higher information } \\
\text { environment quality. }\end{array}$ \\
\hline $\begin{array}{l}\text { Number of Analysts: Natural log of number of analysts } \\
\text { following a firm. }\end{array}$ & $\begin{array}{l}\text { Bhushan (1989), } \\
\text { Alford and Berger } \\
\text { (1999) and Chan } \\
\text { and Hameed } \\
\text { (2006) }\end{array}$ & $\begin{array}{l}\text { The higher number of analysts means a better } \\
\text { information environment. In order to sell the } \\
\text { earning reports to its own customers, each } \\
\text { analyst firm tries to incorporate as much } \\
\text { information as possible from accurate } \\
\text { sources. On the contrary, for a poor firm's } \\
\text { information environment the number of } \\
\text { analysts is lower. }\end{array}$ \\
\hline
\end{tabular}




\begin{tabular}{|l|l|l|}
\hline $\begin{array}{l}\text { Analysts' forecast error: I compute earnings forecast } \\
\text { error as the absolute value of the difference between } \\
\text { the median analyst's quarterly forecast within }+/ 180 \\
\text { days surrounding to CFO replacement announcement } \\
\text { and actual quarterly earnings, scaled by the firm's EPS. }\end{array}$ & $\begin{array}{l}\text { Hilary and Hsu } \\
\text { and Lakonishok } \\
(1979)\end{array}$ & $\begin{array}{l}\text { The lower forecast error means quality } \\
\text { information environment. Because when the } \\
\text { information channels are good, analysts can } \\
\text { acquire quality information without much } \\
\text { noise. "Consensus" forecast can only be } \\
\text { possible if all the analysts following a firm } \\
\text { have the same information. Hilary and Hsu } \\
\text { (2013) argue that price informativeness } \\
\text { depends more on consistent forecast over the } \\
\text { time rather that accuracy. }\end{array}$ \\
\hline $\begin{array}{l}\text { Analysts' forecast dispersion: it is measured as the } \\
\text { standard deviation of earnings forecasts across analysts } \\
\text { prior to a CFO change announcement, normalized by } \\
\text { the firm's fiscal year-end stock price. }\end{array}$ & $\begin{array}{l}\text { Barron et al. } \\
(1998), \text { Barry and }\end{array}$ & $\begin{array}{l}\text { Barron et al. (1998) show that analysts } \\
\text { forecast dispersion is an increasing function } \\
\text { of uncertainty and a decreasing function of } \\
\text { consensus. Therefore, the lower the } \\
\text { dispersion of analysts' forecasts the better the } \\
\text { information environment. Lower dispersion } \\
\text { means analysts following a firm have similar } \\
\text { private (or privileged) information about the } \\
\text { firm. Diversity among analysts increases if } \\
\text { information is distributed unequally even if } \\
\text { the aggregate private information is held } \\
\text { constant (Barry and Jennings 1992). }\end{array}$ \\
\hline
\end{tabular}


Table 3.2 Descriptive Statistics

The following table includes descriptive statistics of Information Environment Variables and Control Variables. I use a one-year window surrounding the CFO appointment date in calculating information environment variables: idiosyncratic variance, synchronicity, natural logarithm of number of analysts, forecast errors, and forecast dispersions. The values for control variables for pre- and-post appointments are from the earliest and latest year of CFO change, respectively. The reason the number of post-appointment observations is smaller than pre-appointment is due to some firms that went bankrupt or stopped trading after the CFO change. Idiosyncratic variance increases after the appointment, which indicates a poorer information environment. Synchronicity increases by $0.173=-0.689-(-0.862)$, which is statistically significant. The natural log of the number of analysts has increased. Both of the increases indicate better information environment. Analysts' forecast error increased, whereas, forecast dispersion stayed the same. Holdings by insiders decreased, while institutional holdings have increased. Natural logarithm of market value increased slightly after the CFO appointment. Operating performance has improved (with a lower negative number) and standard deviation of ROA has decreased. In regards to internal and external appointments, all the parameters indicate somewhat poorer information environment for external appointment, except analysts' forecast error. Insider holdings, institutional holdings, and market value of the CFO changed firms decreased. Operating performance has dampened and standard deviation of operating performance has increased. $* * *, * *$, and $*$ denote statistical significance at the $1 \%, 5 \%$, and $10 \%$ levels, respectively. Type II error or $\beta$ error is falsely accepting an incorrect null hypothesis $\left(\mathrm{H}_{0}\right)$. 1- $\beta$ indicates the power of the test which depends on three parameters: level of significance, sample size and size effect. I use $\mathrm{G}^{*}$ Power 3 program by Faul et al. (2007) (available at http://www.gpower.hhu.de/) to compute the statistical power of the hypotheses. Post hoc power analyses (Cohen 1988) is used as "type" in the computation.

\begin{tabular}{|c|c|c|c|c|c|c|c|}
\hline \multicolumn{8}{|c|}{ Panel A: Comparative statistics between pre and post appointments } \\
\hline & \multicolumn{2}{|c|}{$\begin{array}{c}\text { Pre } \\
\text { Appointment }\end{array}$} & \multicolumn{2}{|c|}{$\begin{array}{c}\text { Post } \\
\text { Appointment }\end{array}$} & \multirow[t]{2}{*}{$\begin{array}{l}\text { Mean diff. } \\
\text { (post-pre) }\end{array}$} & \multirow[t]{2}{*}{$\begin{array}{c}t- \\
\text { value }\end{array}$} & \multirow{2}{*}{$\begin{array}{c}\text { Power } \\
\text { of the } \\
\text { test }\end{array}$} \\
\hline & Mean & SD & Mean & SD & & & \\
\hline Idiosyncratic & & & & & & & \\
\hline variance & 0.054 & 0.028 & 0.055 & 0.031 & 0.0007 & 0.50 & N/A \\
\hline Synchronicity & $(0.862)$ & 1.036 & $(0.689)$ & 1.082 & $0.1731 * * *$ & 3.26 & 0.825 \\
\hline $\begin{array}{l}\text { Ln of no. of } \\
\text { analysts }\end{array}$ & 2.037 & 0.947 & 2.056 & 0.955 & 0.0198 & 0.42 & N/A \\
\hline Forecast errors & 0.058 & 0.695 & 0.065 & 0.682 & 0.0074 & 0.20 & N/A \\
\hline $\begin{array}{l}\text { Forecast } \\
\text { dispersion }\end{array}$ & 0.007 & 0.014 & 0.007 & 0.014 & 0.0002 & 0.28 & N/A \\
\hline Insider holdings & 0.155 & 0.251 & 0.145 & 0.246 & -0.0094 & -0.76 & N/A \\
\hline $\begin{array}{l}\text { Institutional } \\
\text { holdings }\end{array}$ & 0.687 & 0.247 & 0.695 & 0.244 & 0.0082 & 0.67 & N/A \\
\hline $\begin{array}{l}\text { Ln of market } \\
\text { value }\end{array}$ & 20.380 & 1.843 & 20.470 & 1.872 & 0.0901 & 0.97 & N/A \\
\hline
\end{tabular}




\begin{tabular}{|c|c|c|c|c|c|c|c|}
\hline $\mathrm{ROA}$ & $(0.018)$ & 0.194 & $(0.004)$ & 0.180 & $0.0148 *$ & 1.58 & 0.584 \\
\hline SD of ROA & 0.030 & 0.038 & 0.029 & 0.038 & -0.0012 & -0.63 & N/A \\
\hline Observations & \multicolumn{2}{|c|}{825.000} & \multicolumn{2}{|c|}{774.000} & & & \\
\hline \multicolumn{8}{|c|}{ Panel B: Comparative statistics between internal and external appointments } \\
\hline & \multicolumn{2}{|c|}{$\begin{array}{c}\text { Internal } \\
\text { Appointment }\end{array}$} & \multicolumn{2}{|c|}{$\begin{array}{c}\text { External } \\
\text { Appointment }\end{array}$} & Mean diff. & $t-$ & Power \\
\hline & & & & & & & \\
\hline & Mean & SD & Mean & SD & & & \\
\hline \multicolumn{8}{|l|}{ Idiosyncratic } \\
\hline variance & 0.052 & 0.034 & 0.058 & 0.028 & $-0.0057 * * *$ & -2.56 & 0.635 \\
\hline Synchronicity & $(0.612)$ & 1.137 & $(0.775)$ & 1.012 & $0.1631 * *$ & 2.11 & 0.676 \\
\hline \multicolumn{8}{|l|}{ Ln of no. of } \\
\hline analysts & 2.148 & 0.958 & 1.959 & 0.940 & $0.1898 * * *$ & 2.78 & 0.869 \\
\hline Forecast errors & 0.166 & 0.760 & $(0.004)$ & 0.656 & $0.1698 * * *$ & 2.74 & 0.651 \\
\hline \multicolumn{8}{|l|}{ Forecast } \\
\hline dispersion & 0.008 & 0.017 & 0.008 & 0.014 & 0.0002 & 0.13 & N/A \\
\hline Insider holdings & 0.148 & 0.255 & 0.140 & 0.234 & 0.0081 & 0.46 & N/A \\
\hline \multicolumn{8}{|l|}{ Institutional } \\
\hline holdings & 0.707 & 0.231 & 0.682 & 0.258 & 0.0253 & 1.43 & N/A \\
\hline \multicolumn{8}{|l|}{ Ln of market } \\
\hline $\begin{array}{l}\text { value } \\
\text { ROA }\end{array}$ & $\begin{array}{c}20.815 \\
0.005\end{array}$ & $\begin{array}{l}1.992 \\
0.176\end{array}$ & $\begin{array}{l}20.085 \\
(0.013)\end{array}$ & $\begin{array}{l}1.052 \\
0.184\end{array}$ & 0.0185 & $\begin{array}{l}5.5 / \\
1.43\end{array}$ & $\begin{array}{l}1.000 \\
\mathrm{~N} / \mathrm{A}\end{array}$ \\
\hline $\mathrm{SD}$ of $\mathrm{ROA}$ & 0.026 & 0.036 & 0.032 & 0.040 & $-0.0063 * *$ & 2.29 & 0.707 \\
\hline Observations & \multicolumn{2}{|c|}{406.000} & \multicolumn{2}{|c|}{368.000} & & & \\
\hline
\end{tabular}


Table 3.3 T-test of Information Environment Variables

This table includes $t$-tests between treated and controlled firms. There is no significant difference between the two groups. Because the number of control firms is lower than the treatment firms, 801 firms (=1599-798) are picked from the control group by bootstrapping method (random sampling with replacements). Although there are no significant differences among firms that experienced CFO change and firms that have similar features without any CFO change, firms that experienced negative earnings for the last few years consecutively showed significant differences. Four measures of information environment quality proxy variables show significant differences over the past 3-5 years of consecutive negative ROAs. Similar to Mian (2001), I calculated industry adjusted ROA over the last five years. Therefore, it is necessary to separate the distressed firms to determine the impact of CFO change on information environment. ***, **, and * denote statistical significance at the $1 \%, 5 \%$, and $10 \%$ levels, respectively.

\begin{tabular}{|c|c|c|c|c|c|c|}
\hline \multirow{2}{*}{$\frac{\underline{\text { All firms }}}{\text { Variable }}$} & \multicolumn{2}{|c|}{ Mean } & \multicolumn{2}{|c|}{$t$-test } & \multirow[t]{2}{*}{ Significant? } & \multirow[t]{2}{*}{$\begin{array}{c}\text { Power of } \\
\text { the test }\end{array}$} \\
\hline & $\begin{array}{c}\text { Treated } \\
(\mathrm{N}=1599)\end{array}$ & $\begin{array}{c}\text { Control } \\
(\mathrm{N}=1599)\end{array}$ & t-value & $\mathrm{p}>|\mathrm{t}|$ & & \\
\hline Idiosyncratic variance & 0.055 & 0.054 & 0.94 & 0.349 & No & N/A \\
\hline Synchronicity & $(0.778)$ & $(0.776)$ & $(0.06)$ & 0.952 & No & N/A \\
\hline Ln of no. of analysts & 2.046 & 2.088 & $(1.27)$ & 0.205 & No & N/A \\
\hline Forecast errors & 0.061 & 0.032 & 1.11 & 0.267 & No & N/A \\
\hline Forecast dispersion & 0.007 & 0.006 & 1.65 & 0.100 & $*$ & 0.643 \\
\hline Insider holdings & 0.150 & 0.150 & $(0.03)$ & 0.974 & No & N/A \\
\hline Institutional holdings & 0.691 & 0.695 & $(0.43)$ & 0.668 & No & N/A \\
\hline Ln of market value & 20.424 & 20.475 & $(0.76)$ & 0.447 & No & N/A \\
\hline ROA & 0.011 & $(0.007)$ & $(0.65)$ & 0.515 & No & N/A \\
\hline $\begin{array}{l}\text { SD of ROA } \\
-5 \text { Years }\end{array}$ & 0.030 & 0.029 & 0.54 & 0.589 & No & N/A \\
\hline$\overline{\text { Idiosyncratic variance }}$ & 0.078 & 0.088 & $(2.35)$ & 0.020 & $* *$ & 0.757 \\
\hline Ln of no. of analysts & 1.814 & 1.510 & 3.26 & 0.001 & $* * *$ & 0.822 \\
\hline $\begin{array}{l}\text { Forecast dispersion } \\
-4 \text { Years }\end{array}$ & 0.013 & 0.009 & 1.71 & 0.088 & $*$ & 0.665 \\
\hline $\begin{array}{l}\text { N/A } \\
-3 \text { Years }\end{array}$ & N/A & N/A & N/A & N/A & N/A & N/A \\
\hline$\overline{\text { Ln of no. of analysts }}$ & 1.789 & 1.637 & 2.57 & 0.010 & $* * *$ & 0.594 \\
\hline Forecast errors & 0.055 & $(0.068)$ & 1.99 & 0.047 & $* *$ & 0.635 \\
\hline $\begin{array}{l}\text { Forecast dispersion } \\
\underline{-2 \text { Years }}\end{array}$ & 0.013 & 0.009 & 3.00 & 0.003 & $* * *$ & 0.749 \\
\hline$\overline{\text { Ln of no. of analysts }}$ & 1.805 & 1.695 & 2.06 & 0.039 & $* *$ & 0.662 \\
\hline $\begin{array}{l}\text { Forecast dispersion } \\
-1 \text { Year }\end{array}$ & 0.012 & .009 & 3.37 & 0.001 & $* * * *$ & 0.850 \\
\hline$\overline{\text { Forecast errors }}$ & 0.044 & -0.040 & 1.67 & 0.095 & $*$ & 0.651 \\
\hline Forecast dispersion & 0.011 & 0.009 & 2.35 & 0.019 & $* *$ & 0.758 \\
\hline
\end{tabular}




\section{Table 3.4 Expected Signs}

The following table includes the expected signs from the multivariate analysis. From consultation with the existing literature, I posit that if a firm employs a new CFO, the appointment should reduce the noise in the market hence the idiosyncratic variance. The relation between IDV and synchronicity is negative (lower errors or IDV increases $\mathrm{R}^{2}$ and vice versa in the equation presented in Table 3.1, row 1). The higher number of analysts would increase the information availability in the market. If the information eco-system is good, then both the analysts' forecast error and dispersion should be lower. The presence of a higher number of analysts reduces idiosyncratic variance and increases synchronicity. The higher proportion of ownership by insiders and institutions increase the quality of the information environment. Typically, a big firm has a better information environment due to having a higher number of analysts following the firm, an internal audit department, regular press release and other aid to quality information. The relationship between ROA and the number of analysts is not clear due to the fact that both good firms and distressed firms can be followed by a large number of analysts. The volatility of earnings (SD of ROA) is positively related with IDV, forecast error and dispersion and negatively related to synchronicity. The expected sign under the number of analysts is ambiguous.

\begin{tabular}{|c|c|c|}
\hline $\begin{array}{l}\text { Panel A: Dependent variables } \\
\text { Proxy variables to firm's information } \\
\text { environment }\end{array}$ & Expected sign & Description \\
\hline $\begin{array}{l}\text { Idiosyncratic variance (or noise or diversifiable } \\
\text { risk) }\end{array}$ & +2 & $\begin{array}{l}\text { Improve the info. } \\
\text { Environment }\end{array}$ \\
\hline Synchronicity & + & $\begin{array}{l}\text { Improve the info. } \\
\text { Environment }\end{array}$ \\
\hline Ln of number of analysts & + & $\begin{array}{l}\text { Improve the info. } \\
\text { Environment }\end{array}$ \\
\hline Forecast error & - & $\begin{array}{l}\text { Improve the info. } \\
\text { Environment }\end{array}$ \\
\hline Forecast dispersion & - & $\begin{array}{l}\text { Improve the info. } \\
\text { Environment }\end{array}$ \\
\hline Panel B: Independent variables & $\begin{array}{l}\text { Expected Sign } \\
\text { Dep. Variables }\end{array}$ & \\
\hline Ln of no. of analysts ${ }^{\dagger}$ &,-+ & $\begin{array}{l}\text { IDV should go } \\
\text { down and sync. } \\
\text { should go up }\end{array}$ \\
\hline Insider holdings &,,,,-++-- & \\
\hline Institutional holdings &,,,,-++-- & \\
\hline Ln of market value &,,,,-++-- & \\
\hline ROA & $-,+, ?,-,-$ & \\
\hline SDROA & $+,-, ?,+,+$ & \\
\hline
\end{tabular}

$\dagger$ (note: previous literature uses this variable with idiosyncratic variance and synchronicity in similar type of specification) 
Table 3.5 Multivariate Analysis (All Firms)

This table includes multivariate analysis using all firms together. Propensity score matching is used to pick the same number of control firms as treatment firms. In the first stage, a logit regression was run in which an indicator variable (CFO change firm $=1$, otherwise $=0$ ) is used as a dependent variable and the number of analysts, insider holdings, institutional holdings, market capitalization, earnings and volatility of earnings are used as independent variables. In the second stage, the same group of independent variables along with "post," "treatment," and "post*treatment" are used to test their impacts on information environment proxy variables: idiosyncratic variance, synchronicity, natural log of the number of analysts, analysts forecast errors and forecast dispersion. The variable of interest in this framework is the interaction term between post and treatment (=Post*Treatment). Post is an indicator variable taking value of 1 for the period after the CFO change, otherwise it takes a value of 0 . Treatment is also an indicator variable which takes a value of 1 for being a firm from the CFO change group, otherwise it takes a value of 0 . The interaction term tells us the nature and significance of effect a CFO change has on the firm's information environment. Even though post is significant at the $1 \%$ level under "synchronicity" the interaction term is not significant in any of the models. The number of analysts should increase the quality of firm's information environment, i.e., it should have a negative coefficient under the first model and positive coefficient under synchronicity. Although the number of analysts does not have the correct sign under IDV, the other independent variables have the correct signs. $t$-statistics are in parentheses. ***,**, and * denote statistical significance at the $1 \%, 5 \%$, and $10 \%$ levels, respectively. Type II error or $\beta$ error is falsely accepting an incorrect null hypothesis $\left(\mathrm{H}_{0}\right)$. 1- $\beta$ indicates the power of the test which depends on three parameters: level of significance, sample size and size effect. I use 5\% level of significance, actual sample size and size effect from $\mathrm{R}^{2}$ in calculating 1$\beta$. I use the $G^{*}$ Power 3 program by Faul et al. (2007) (available at http://www.gpower.hhu.de/) to compute the statistical power of the hypotheses. Post hoc power analyses (Cohen 1988) is used as "type" in the computation.

\begin{tabular}{lccccc}
\hline & $\begin{array}{c}\text { Idiosyncratic } \\
\text { variance }\end{array}$ & Synchronicity & $\begin{array}{c}\text { Ln of no. } \\
\text { of analysts }\end{array}$ & $\begin{array}{c}\text { Forecast } \\
\text { errors }\end{array}$ & $\begin{array}{c}\text { Forecast } \\
\text { dispersion }\end{array}$ \\
\hline Post & -0.00002 & $0.131 * * *$ & 0.010 & -0.035 & 0.00047 \\
Treatment & $(-0.01)$ & $(2.89)$ & $(0.33)$ & $(-0.94)$ & -0.710 \\
& 0.000 & 0.006 & -0.019 & 0.013 & 0.001 \\
Post*Treatment & $(-0.29)$ & $(0.13)$ & $(-0.61)$ & $(0.35)$ & $(1.23)$ \\
& 0.002 & 0.013 & -0.019 & 0.040 & 0.00008 \\
Ln of no. of & $(1.10)$ & $(0.20)$ & $(-0.42)$ & $(0.76)$ & $(0.09)$ \\
analysts & $0.005 * * *$ & $0.053 * *$ & & & \\
Insider & $(6.85)$ & $(2.14)$ & & & \\
holdings & & & & & \\
& 0.000 & $-0.211 * * *$ & $0.140 * * *$ & 0.048 & $-0.002 * *$ \\
& $(-0.16)$ & $(-3.15)$ & $(2.92)$ & $(0.88)$ & $(-2.27)$
\end{tabular}




\begin{tabular}{lccccc} 
Institutional & & & & \\
holdings & $-0.019 * * *$ & $0.424 * * *$ & $0.725 * * *$ & 0.068 & $-0.009 * * *$ \\
& $(-9.49)$ & $(5.77)$ & $(14.31)$ & $(1.10)$ & $(-7.94)$ \\
Ln of market & & & & & \\
value & $-0.007 * * *$ & $0.203 * * *$ & $0.338 * * *$ & $-0.016 *$ & $-0.001 * * *$ \\
& $(-19.77)$ & $(15.85)$ & $(47.79)$ & $(-1.89)$ & $(-8.63)$ \\
ROA & $-0.023 * * *$ & $0.247 * *$ & $-0.484 * * *$ & $0.458 * * *$ & $-0.017 * * *$ \\
& $(-8.38)$ & $(2.44)$ & $(-6.78)$ & $(5.29)$ & $(-10.59)$ \\
SD of ROA & $0.110 * * *$ & -0.655 & -0.127 & -0.063 & $0.047 * * *$ \\
& $(8.20)$ & $(-1.32)$ & $(-0.37)$ & $(-0.15)$ & $(5.97)$ \\
Constant & $0.194 * * *$ & $-5.338 * * *$ & $-5.367 * * *$ & $0.322 *$ & $0.038 * * *$ \\
& $(30.98)$ & $(-23.11)$ & $(-38.41)$ & $(1.89)$ & $(12.32)$ \\
NOBS & 3,198 & 3,198 & 3,198 & 2,904 & 2,850 \\
R-squared & 0.345 & 0.256 & 0.561 & 0.016 & 0.247 \\
Power of the & & & & & \\
test & 1.000 & 1.000 & 1.000 & 1.000 & 1.000 \\
\hline
\end{tabular}


Table 3.6 Multivariate analysis (-5 years)

Similar to Mian (2001), I separate the firms that are producing negative industry adjusted ROA for the last 5 years prior to CFO replacement. Propensity score matching is used to pick the same number of control firms as treatment firms. In the first stage, a logit regression was run in which an indicator variable $(\mathrm{CFO}$ changed firm $=1$, otherwise $=0)$ is used as a dependent variable and the number of analysts, insider holdings, institutional holdings, market capitalization, earnings, and volatility of earnings are used as independent variables. In the second stage, the same procedure was followed as previously mentioned in Table 3.5. Out of five proxies of information environment, two are significantly affected by the CFO turnover. For example, idiosyncratic variance is reduced by 0.019 unit for firms which have replaced their CFOs vis-à-vis firms that did not replace. In addition, analysts' forecast errors have reduced for the firms which replaced their CFOs. Other independent variables are in line with the expected signs outlined in Table 3.4. $t$-statistics are in parentheses. $* * *, * *$, and $*$ denote statistical significance at the $1 \%, 5 \%$, and $10 \%$ levels, respectively. The power of the test is computed by the $G^{*}$ Power 3 by Faul et al. (2007).

\begin{tabular}{lccccc}
\hline & $\begin{array}{c}\text { Idiosyncratic } \\
\text { variance }\end{array}$ & Synchronicity & $\begin{array}{c}\text { Ln of no. of } \\
\text { analysts }\end{array}$ & $\begin{array}{c}\text { Forecast } \\
\text { errors }\end{array}$ & $\begin{array}{c}\text { Forecast } \\
\text { dispersion }\end{array}$ \\
\hline Post & $0.026^{* * *}$ & 0.10 & 0.04 & $0.393 * * *$ & 0.00 \\
Treatment & $(4.71)$ & $(0.92)$ & $(0.48)$ & $(3.31)$ & $(1.37)$ \\
& 0.000 & -0.090 & 0.150 & $0.298^{* *}$ & $0.005^{*}$ \\
Post*Treatment & $(0.78)$ & $(-0.75)$ & $(1.58)$ & $(2.44)$ & $(1.91)$ \\
& $-0.019 * *$ & -0.080 & 0.030 & $-0.508^{* * *}$ & $(0.00)$ \\
Ln of no. of & $(-2.48)$ & $(-0.53)$ & $(0.26)$ & $(-3.03)$ & $(-0.80)$ \\
analysts & $-0.008^{* *}$ & 0.03 & & & \\
& $(-2.41)$ & $(0.41)$ & & & \\
Insider holdings & 0.010 & -0.030 & 0.100 & $-0.430^{* *}$ & 0.00 \\
& $(-1.64)$ & $(-0.19)$ & $(0.75)$ & $(-2.39)$ & $(0.60)$ \\
Institutional & $-0.041^{* * *}$ & $0.559^{* * *}$ & $0.844^{* * *}$ & 0.110 & $-0.008^{*}$ \\
holdings & $(-4.15)$ & $(2.81)$ & $(5.80)$ & $(0.52)$ & $(-1.96)$ \\
& 0.000 & $0.262^{* * *}$ & $0.419^{* * *}$ & $(0.00)$ & 0.00 \\
Ln of market value & $(0.33)$ & $(6.28)$ & $(16.75)$ & $(-0.12)$ & $(-0.06)$ \\
& -0.010 & $0.317 *$ & $-0.406^{* * *}$ & $0.300^{*}$ & $-0.013^{* * *}$ \\
ROA & $(-1.54)$ & $(1.91)$ & $(-3.24)$ & $(1.70)$ & $(-3.65)$ \\
& -0.060 & -0.320 & 0.90 & -0.610 & 0.000 \\
SD of ROA & $(-1.41)$ & $(-0.37)$ & $(1.42)$ & $(-0.63)$ & $(0.11)$ \\
& $0.099^{* * *}$ & $-6.332^{* * *}$ & $-7.166^{* * *}$ & 0.030 & 0.010 \\
Constant & $(2.71)$ & $(-8.65)$ & $(-15.88)$ & $(-0.05)$ & $(0.78)$ \\
& 402 & 402 & 402 & 346 & 336 \\
NOBS & 0.203 & 0.339 & 0.62 & 0.066 & 0.114 \\
R-squared & 1.000 & 1.000 & 1.000 & 0.960 & 0.999 \\
Power of the test & & & & &
\end{tabular}


Table 3.7 Multivariate Analysis (-4 years)

Similar to Mian (2001), I separate the firms that are producing negative industry adjusted ROA for the last 4 years prior to CFO replacement. Propensity score matching is used to pick the same number of control firms as treatment firms. In the first stage, a logit regression was run in which an indicator variable $(\mathrm{CFO}$ change firm $=1$, otherwise $=0)$ is used as dependent and the number of analysts, insider holdings, institutional holdings, market capitalization, earnings, and volatility of earnings are used as independent variables. In the second stage, the same procedure was followed as previously mentioned in Table 3.5. Out of five information environment proxies, one is marginally affected (at $10 \%$ ) by the CFO turnover. For example, analysts' forecast errors have reduced by 0.275 units for the firms which replaced their CFOs. Other independent variables are in line with the expected signs outlined in Table 4. $t$-statistics are in parentheses. ***, **, and $*$ denote statistical significance at the $1 \%, 5 \%$, and $10 \%$ levels, respectively. The power of the test is computed by the G*Power 3 program by Faul et al. (2007).

\begin{tabular}{lccccc}
\hline & $\begin{array}{c}\text { Idiosyncratic } \\
\text { variance }\end{array}$ & Synchronicity & $\begin{array}{c}\text { Ln of no. of } \\
\text { analysts }\end{array}$ & $\begin{array}{c}\text { Forecast } \\
\text { errors }\end{array}$ & $\begin{array}{c}\text { Forecast } \\
\text { dispersion }\end{array}$ \\
\hline Post & 0.000 & 0.072 & -0.024 & $0.232^{* *}$ & $-0.004^{*}$ \\
Treatment & $(0.11)$ & $(0.75)$ & $(-0.33)$ & $(2.19)$ & $(-1.90)$ \\
Post*Treatment & -0.001 & -0.145 & -0.002 & 0.127 & -0.002 \\
& $(-0.33)$ & $(-1.49)$ & $(-0.03)$ & $(1.17)$ & $(-0.76)$ \\
Ln of no. of analysts & 0.004 & 0.030 & 0.033 & $-0.275^{*}$ & 0.005 \\
& $(0.76)$ & $(0.22)$ & $(0.33)$ & $(-1.83)$ & $(1.43)$ \\
Insider holdings & -0.003 & $0.188^{* * *}$ & & & \\
Institutional holdings & $(-1.27)$ & $(3.50)$ & & & \\
& -0.001 & -0.242 & -0.054 & $-0.535^{* * *}$ & 0.003 \\
Ln of market value & $(-0.11)$ & $(-1.42)$ & $(-0.48)$ & $(-3.27)$ & $(0.82)$ \\
& $-0.023 * * *$ & $0.336 * *$ & $0.767 * * *$ & 0.001 & $-0.014 * * *$ \\
ROA & $(-3.57)$ & $(2.14)$ & $(6.67)$ & $(0.01)$ & $(-3.83)$ \\
SD of ROA & 0.000 & $0.196^{* * *}$ & $0.364 * * *$ & -0.028 & -0.001 \\
& $(0.25)$ & $(5.79)$ & $(17.93)$ & $(-0.90)$ & $(-1.21)$ \\
Constant & $-0.023 * * *$ & 0.199 & $-0.513 * * *$ & 0.241 & $-0.015 * * *$ \\
NOBS & $(-3.92)$ & $(1.39)$ & $(-4.69)$ & $(1.52)$ & $(-4.17)$ \\
R-squared & $0.052 *$ & $-1.804 * *$ & 0.302 & $-2.255^{* *}$ & $0.046^{* *}$ \\
Power of the test & $(1.74)$ & $(-2.42)$ & $(0.53)$ & $(-2.55)$ & $(2.49)$ \\
& $0.079 * * *$ & $-5.166^{* * *}$ & $-5.836 * * *$ & 0.66 & $0.035^{* * *}$ \\
& $(3.24)$ & $(-8.63)$ & $(-15.57)$ & $(1.11)$ & $(2.78)$ \\
& 632 & 632 & 632 & 538 & 530 \\
& 0.119 & 0.28 & 0.515 & 0.046 & 0.176 \\
& 1.000 & 1.000 & 1.000 & 0.972 & 1.000 \\
\hline
\end{tabular}


Table 3.8 Multivariate Analysis (-3 years)

Similar to Mian (2001), I separate the firms that are producing negative industry adjusted ROA for the last 3 years prior to CFO replacement. Propensity score matching is used to pick the same number of control firms as treatment firms. In the first stage, a logit regression was run in which an indicator variable $(\mathrm{CFO}$ change firm $=1$, otherwise $=0)$ is used as dependent and the number of analysts, insider holdings, institutional holdings, market capitalization, earnings, and volatility of earnings are used as independent variables. In the second stage, the same procedure was followed as previously mentioned in Table 3.5. Out of five proxies of information environment variables, two proxies are affected by the CFO turnover. For example, synchronous trading of stocks of the distressed companies increases after they replace their CFOs. In addition, more analysts are attracted after distressed companies change their CFOs. Other independent variables are in line with the expected signs outlined in Table 4. $t$-statistics are in parentheses. ***, **, and * denote statistical significance at the $1 \%, 5 \%$, and $10 \%$ levels, respectively. The power of the test is computed by the G*Power 3 program by Faul et al. (2007).

\begin{tabular}{|c|c|c|c|c|c|}
\hline & $\begin{array}{c}\text { Idiosyncratic } \\
\text { variance }\end{array}$ & Synchronicity & $\begin{array}{c}\text { Ln of no. of } \\
\text { analysts }\end{array}$ & $\begin{array}{c}\text { Forecast } \\
\text { errors }\end{array}$ & $\begin{array}{c}\text { Forecast } \\
\text { dispersion }\end{array}$ \\
\hline \multirow[t]{2}{*}{ Post } & $0.007 * *$ & $(0.12)$ & $-0.169 * * *$ & 0.03 & 0.00 \\
\hline & $(2.39)$ & $(-1.47)$ & $(-2.86)$ & $(0.39)$ & $(1.21)$ \\
\hline \multirow[t]{2}{*}{ Treatment } & 0.00 & $-0.203 * *$ & 0.03 & $0.144 *$ & $0.003 * *$ \\
\hline & $(1.13)$ & $(-2.55)$ & $(0.52)$ & $(1.68)$ & $(1.98)$ \\
\hline \multirow[t]{2}{*}{ Post*Treatment } & $(0.00)$ & $0.212 *$ & $0.221 * * *$ & $(0.06)$ & 0.00 \\
\hline & $(-0.48)$ & $(1.86)$ & $(2.65)$ & $(-0.50)$ & $(0.23)$ \\
\hline \multirow[t]{2}{*}{ Ln of no. of analysts } & 0.00 & $0.074 *$ & & & \\
\hline & $(-0.15)$ & $(1.68)$ & & & \\
\hline \multirow[t]{2}{*}{ Insider holdings } & 0.00 & $(0.06)$ & $(0.09)$ & $-0.253 *$ & $(0.00)$ \\
\hline & $(0.71)$ & $(-0.51)$ & $(-0.91)$ & $(-1.81)$ & $(-1.00)$ \\
\hline \multirow[t]{2}{*}{ Institutional holdings } & $-0.023 * * *$ & $0.374 * * *$ & $0.863 * * *$ & $(0.09)$ & $-0.009 * * *$ \\
\hline & $(-4.72)$ & $(2.80)$ & $(9.19)$ & $(-0.58)$ & $(-3.46)$ \\
\hline \multirow[t]{2}{*}{ Ln of market value } & 0.000 & $0.261 * * *$ & $0.341 * * *$ & 0.02 & $-0.002 * * *$ \\
\hline & $(-1.19)$ & $(9.20)$ & $(20.43)$ & $(0.70)$ & $(-4.26)$ \\
\hline \multirow[t]{2}{*}{$\mathrm{ROA}$} & $-0.018 * * *$ & $0.332 * *$ & $-0.337 * * *$ & $0.479 * * *$ & $-0.018 * * *$ \\
\hline & $(-3.76)$ & $(2.51)$ & $(-3.60)$ & $(3.57)$ & $(-6.94)$ \\
\hline \multirow[t]{2}{*}{$\mathrm{SD}$ of $\mathrm{ROA}$} & $0.076 * * *$ & $-1.202 *$ & $0.904 *$ & $(0.35)$ & $0.025^{*}$ \\
\hline & $(3.01)$ & $(-1.71)$ & $(1.86)$ & $(-0.47)$ & $(1.88)$ \\
\hline \multirow[t]{2}{*}{ Constant } & $0.096 * * *$ & $-6.272 * * *$ & $-5.516 * * *$ & $(0.27)$ & $0.051 * * *$ \\
\hline & $(5.31)$ & $(-12.55)$ & $(-17.97)$ & $(-0.55)$ & $(5.72)$ \\
\hline NOBS & 916 & 916 & 916 & 788 & 782 \\
\hline R-squared & 0.133 & 0.291 & 0.516 & 0.034 & 0.228 \\
\hline Power of the test & 1.000 & 1.000 & 1.000 & 0.981 & 1.000 \\
\hline
\end{tabular}


Table 3.9 Multivariate Analysis (-2 years)

Similar to Mian (2001), I separate the firms that are producing negative industry adjusted ROA for the last 2 years prior to CFO replacement. Propensity score matching is used to pick the same number of control firms as treatment firms. In the first stage, a logit regression was run in which an indicator variable $(\mathrm{CFO}$ change firm $=1$, otherwise $=0)$ is used as dependent and the number of analysts, insider holdings, institutional holdings, market capitalization, earnings, and volatility of earnings are used as independent variables. In the second stage, the same procedure was followed as previously mentioned in Table 3.5. None of the proxies for the information environment is significant in post$\mathrm{CFO}$ turnover. The number of analysts following the firm increases synchronous trading of the firm's stocks. Other independent variables are in line with the expected signs outlined in Table 4. $t$-statistics are in parentheses. $* * *, * *$, and $*$ denote statistical significance at the $1 \%, 5 \%$, and $10 \%$ levels, respectively. The power of the test is computed by the G*Power 3 program by Faul et al. (2007).

\begin{tabular}{|c|c|c|c|c|c|}
\hline & $\begin{array}{c}\text { Idiosyncratic } \\
\text { variance }\end{array}$ & Synchronicity & $\begin{array}{l}\text { Ln of no. } \\
\text { of analysts }\end{array}$ & $\begin{array}{c}\text { Forecast } \\
\text { errors }\end{array}$ & $\begin{array}{c}\text { Forecast } \\
\text { dispersion }\end{array}$ \\
\hline Post & $\begin{array}{c}0.008 * * * \\
(3.20)\end{array}$ & $\begin{array}{c}0.04 \\
(0.60)\end{array}$ & $\begin{array}{l}(0.02) \\
(-0.20)\end{array}$ & $\begin{array}{l}(0.13) \\
(-1.52)\end{array}$ & $\begin{array}{c}0.004 * * * \\
(2.79)\end{array}$ \\
\hline Treatment & $\begin{array}{c}0.00 \\
(1.28)\end{array}$ & $\begin{array}{l}-0.119 * \\
(-1.65)\end{array}$ & $\begin{array}{l}(0.10) \\
(-1.41)\end{array}$ & $\begin{array}{l}(0.03) \\
(-0.32)\end{array}$ & $\begin{array}{c}0.004 * * * \\
(3.23)\end{array}$ \\
\hline Post*Treatment & $\begin{array}{l}-0.003 \\
(-0.81)\end{array}$ & $\begin{array}{l}0.038 \\
(0.38)\end{array}$ & $\begin{array}{l}0.116 \\
(1.07)\end{array}$ & $\begin{array}{l}0.159 \\
(1.34)\end{array}$ & $\begin{array}{l}-0.001 \\
(-0.48)\end{array}$ \\
\hline $\begin{array}{l}\text { Ln of no. of } \\
\text { analysts }\end{array}$ & $\begin{array}{c}0.00 \\
(0.74)\end{array}$ & $\begin{array}{c}0.107 * * * \\
(2.72)\end{array}$ & & & \\
\hline Insider holdings & $\begin{array}{c}0.00 \\
(1.02)\end{array}$ & $\begin{array}{c}-0.234 * * \\
(-2.10)\end{array}$ & $\begin{array}{l}(0.20) \\
(-1.61)\end{array}$ & $\begin{array}{c}0.00 \\
(0.03)\end{array}$ & $\begin{array}{c}-0.003 * \\
(-1.78)\end{array}$ \\
\hline $\begin{array}{l}\text { Institutional } \\
\text { holdings }\end{array}$ & $\begin{array}{c}-0.014 * * * \\
(-3.39)\end{array}$ & $\begin{array}{c}0.503 * * * \\
(4.34)\end{array}$ & $\begin{array}{c}0.299 * * \\
(2.45)\end{array}$ & $\begin{array}{c}0.260 * \\
(1.84)\end{array}$ & $\begin{array}{c}-0.007 * * * \\
(-3.26)\end{array}$ \\
\hline Ln of market value & $\begin{array}{c}-0.006 * * * \\
(-6.13)\end{array}$ & $\begin{array}{c}0.251 * * * \\
(10.13)\end{array}$ & $\begin{array}{c}0.289 * * * \\
(13.71)\end{array}$ & $\begin{array}{c}-0.053 * * \\
(-2.12)\end{array}$ & $\begin{array}{c}-0.002 * * * \\
(-5.13)\end{array}$ \\
\hline ROA & $\begin{array}{c}-0.021 * * * \\
(-4.78)\end{array}$ & $\begin{array}{c}0.707 * * * \\
(5.90)\end{array}$ & $\begin{array}{c}0.20 \\
(1.58)\end{array}$ & $\begin{array}{c}0.324 * * \\
(2.20)\end{array}$ & $\begin{array}{c}-0.015 * * * \\
(-6.51)\end{array}$ \\
\hline SD of ROA & $\begin{array}{c}0.084 * * * \\
(3.94)\end{array}$ & $\begin{array}{c}2.031 * * * \\
(3.47)\end{array}$ & $\begin{array}{l}(1.03) \\
(-1.61)\end{array}$ & $\begin{array}{c}-1.311 * \\
(-1.77)\end{array}$ & $\begin{array}{c}0.033 * * * \\
(2.92)\end{array}$ \\
\hline Constant & $\begin{array}{c}0.171 * * * \\
(10.70)\end{array}$ & $\begin{array}{c}-6.398 * * * \\
(-14.68)\end{array}$ & $\begin{array}{c}-6.790 * * * \\
(-17.48)\end{array}$ & $\begin{array}{c}0.998 * * \\
(2.14)\end{array}$ & $\begin{array}{c}0.047 * * * \\
(6.52)\end{array}$ \\
\hline R-squared & 0.197 & 0.323 & 0.244 & 0.021 & 0.221 \\
\hline OBS & 1194 & 1194 & 1194 & 1038 & 1030 \\
\hline Power of the test & 1.000 & 1.000 & 1.000 & 0.943 & 1.000 \\
\hline
\end{tabular}


Table 3.10 Multivariate Analysis (-1 year)

Similar to Mian (2001), I separate the firms that are producing negative industry adjusted $\mathrm{ROA}$ in the year prior to CFO replacement. Propensity score matching is used to pick the same number of control firms as treatment firms. In the first stage, a logit regression was run in which an indicator variable $(\mathrm{CFO}$ change firm $=1$, otherwise $=0$ ) is used as dependent and the number of analysts, insider holdings, institutional holdings, market capitalization, earnings, and volatility of earnings are used as independent variables. In the second stage, the same procedure was followed as previously mentioned in Table 3.5. None of the proxies for the information environment is significant in post-CFO turnover. Higher institutional ownership and bigger firms improve information environment by attracting more analysts and reducing their dispersion. Other independent variables are in line with the expected signs outlined in Table 4 . $t$-statistics are in parentheses. ***, **, and $*$ denote statistical significance at the $1 \%, 5 \%$, and $10 \%$ levels, respectively. The power of the test is computed by the $\mathrm{G}^{*}$ Power 3 program by Faul et al. (2007).

\begin{tabular}{|c|c|c|c|c|c|}
\hline & $\begin{array}{c}\text { Idiosyncratic } \\
\text { variance }\end{array}$ & Synchronicity & $\begin{array}{c}\text { Ln of no. of } \\
\text { analysts }\end{array}$ & $\begin{array}{c}\begin{array}{c}\text { Forecast } \\
\text { errors }\end{array} \\
\end{array}$ & $\begin{array}{c}\text { Forecast } \\
\text { dispersion }\end{array}$ \\
\hline \multirow[t]{2}{*}{ Post } & $0.008 * * *$ & $0.246 * * *$ & $-0.098 * *$ & $-0.116^{*}$ & -0.001 \\
\hline & $(3.56)$ & $(3.87)$ & $(-2.05)$ & $(-1.65)$ & $(-0.71)$ \\
\hline \multirow[t]{2}{*}{ Treatment } & $0.004 *$ & -0.049 & -0.019 & 0.010 & 0.001 \\
\hline & $(1.81)$ & $(-0.77)$ & $(-0.40)$ & $(0.15)$ & $(0.82)$ \\
\hline \multirow[t]{2}{*}{ Post*Treatment } & -0.003 & -0.110 & 0.082 & 0.105 & 0.003 \\
\hline & $(-1.17)$ & $(-1.23)$ & $(1.21)$ & $(1.06)$ & $(1.49)$ \\
\hline \multicolumn{6}{|l|}{ Ln of no. of } \\
\hline \multirow[t]{2}{*}{ analysts } & 0.001 & 0.033 & & & \\
\hline & $(1.01)$ & $(0.98)$ & & & \\
\hline \multirow[t]{2}{*}{ Insider holdings } & 0.003 & -0.093 & -0.110 & 0.034 & $-0.004 *$ \\
\hline & $(0.77)$ & $(-0.93)$ & $(-1.42)$ & $(0.30)$ & $(-1.91)$ \\
\hline \multicolumn{6}{|l|}{ Institutional } \\
\hline holdings & $\begin{array}{c}-0.017 * * * \\
(-4.94)\end{array}$ & $\begin{array}{c}0.350 * * * \\
(3.31)\end{array}$ & $\begin{array}{c}0.692 * * * \\
(8.86)\end{array}$ & $\begin{array}{l}0.084 \\
(0.71)\end{array}$ & $\begin{array}{c}-0.010 * * * \\
(-4.74)\end{array}$ \\
\hline Ln of market value & $\begin{array}{c}-0.005 * * * \\
(-7.23)\end{array}$ & $\begin{array}{c}0.288 * * * \\
(13.88)\end{array}$ & $\begin{array}{c}0.345^{* * * *} \\
(26.13)\end{array}$ & $\begin{array}{l}-0.009 \\
(-0.46)\end{array}$ & $\begin{array}{c}-0.002 * * * \\
(-5.67)\end{array}$ \\
\hline ROA & $\begin{array}{c}-0.025 * * * \\
(-6.69)\end{array}$ & $\begin{array}{l}0.158 \\
(1.40)\end{array}$ & $\begin{array}{c}-0.490 * * * \\
(-5.68)\end{array}$ & $\begin{array}{c}0.538 * * * \\
(4.18)\end{array}$ & $\begin{array}{c}-0.005^{* *} \\
(-2.17)\end{array}$ \\
\hline SD of ROA & $\begin{array}{c}0.046 * * \\
(2.47)\end{array}$ & $\begin{array}{l}-0.860 \\
(-1.55)\end{array}$ & $\begin{array}{l}-0.010 \\
(-0.02)\end{array}$ & $\begin{array}{l}-0.397 \\
(-0.62)\end{array}$ & $\begin{array}{c}0.113 * * * \\
(9.73)\end{array}$ \\
\hline Constant & $\begin{array}{c}0.162 * * * \\
(13.15)\end{array}$ & $\begin{array}{c}-6.934 * * * \\
(-18.74)\end{array}$ & $\begin{array}{c}-5.419 * * * \\
(-21.66)\end{array}$ & $\begin{array}{l}0.221 \\
(0.59)\end{array}$ & $\begin{array}{c}0.050 * * * \\
(7.65)\end{array}$ \\
\hline OBS & 1560 & 1560 & 1560 & 1378 & 1344 \\
\hline R-squared & 0.208 & 0.293 & 0.463 & 0.029 & 0.214 \\
\hline Power of the test & 1.000 & 1.000 & 1.000 & 0.999 & 1.000 \\
\hline
\end{tabular}


Table 3.11 Multivariate Analysis for Internal CFO Appointment (All Firms)

In this table, I report the effects for a promoted CFO on the firm's information environment. Internal is an indicator variable which takes a value of 1 , if the CFO is promoted, and 0 , if the hired CFO is from outside. Both types of firms, good and distressed, are put together in this regression. Although post is significant under a couple of measures and internal is significant under synchronicity, their interaction is not significant under any measure of information environment. Therefore, I cannot conclusively comment on the effect of internal appointments on a firm's information environment. The effects of other variables are in line with the expected signs outlined in Table 4. $t$-statistics are in parentheses. ***, $* *$, and $*$ denote statistical significance at the $1 \%, 5 \%$, and $10 \%$ levels, respectively. The power of the test is computed by the G*Power 3 program by Faul et al. (2007).

\begin{tabular}{|c|c|c|c|c|c|}
\hline & $\begin{array}{c}\text { Idiosyncratic } \\
\text { variance }\end{array}$ & Synchronicity & $\begin{array}{l}\text { Ln of no. of } \\
\text { analysts }\end{array}$ & $\begin{array}{l}\text { Forecast } \\
\text { errors }\end{array}$ & $\begin{array}{l}\text { Forecast } \\
\text { dispersion }\end{array}$ \\
\hline \multirow[t]{2}{*}{ Post } & -0.001 & -0.045 & $-0.083^{*}$ & 0.039 & $0.002 *$ \\
\hline & $(-0.65)$ & $(-0.70)$ & $(-1.81)$ & $(0.77)$ & $(1.95)$ \\
\hline \multirow[t]{2}{*}{ Internal } & 0.001 & $0.138 * *$ & -0.015 & -0.053 & 0.001 \\
\hline & $(0.48)$ & $(2.12)$ & $(-0.32)$ & $(-0.99)$ & $(0.96)$ \\
\hline \multirow[t]{2}{*}{ Post*Internal } & 0.002 & 0.019 & 0.004 & 0.117 & 0.000 \\
\hline & $(0.67)$ & $(0.21)$ & $(0.06)$ & $(1.61)$ & $(-0.24)$ \\
\hline \multirow[t]{2}{*}{ Ln of no. of analysts } & $0.003 * * *$ & 0.04 & & & \\
\hline & (3.66) & (1.16) & & & \\
\hline \multirow[t]{2}{*}{ Insider holdings } & -0.003 & $-0.275 * * *$ & $0.143 * *$ & -0.011 & $-0.003 * *$ \\
\hline & $(-1.13)$ & $(-2.96)$ & $(2.13)$ & $(-0.15)$ & $(-2.51)$ \\
\hline \multirow[t]{2}{*}{ Institutional holdings } & $-0.022 * * *$ & $0.485 * * *$ & $0.817 * * *$ & -0.079 & $-0.010 * * *$ \\
\hline & $(-7.75)$ & $(4.55)$ & (10.99) & $(-0.91)$ & $(-6.86)$ \\
\hline \multirow[t]{2}{*}{ Ln of market value } & $-0.007 * * *$ & $0.217 * * *$ & $0.347 * * *$ & $-0.023^{*}$ & $-0.001 * * *$ \\
\hline & $(-13.10)$ & (11.4) & $(32.41)$ & $(-1.94)$ & $(-5.23)$ \\
\hline \multirow[t]{2}{*}{ ROA } & $-0.015 * * *$ & 0.199 & $-0.640 * * *$ & $0.393 * * *$ & $-0.027 * * *$ \\
\hline & $(-3.66)$ & (1.33) & $(-5.95)$ & $(3.16)$ & $(-12.31)$ \\
\hline \multirow[t]{2}{*}{$\mathrm{SD}$ of $\mathrm{ROA}$} & $0.126 * * *$ & $-2.093 * * *$ & -0.083 & $-0.975^{*}$ & $0.044 * * *$ \\
\hline & $(6.87)$ & $(-3.03)$ & $(-0.17)$ & $(-1.65)$ & $(4.36)$ \\
\hline \multirow[t]{2}{*}{ Constant } & $0.194 * * *$ & $-5.567 * * *$ & $-5.584 * * *$ & $0.606 * *$ & $0.034 * * *$ \\
\hline & (20.94) & $(-15.92)$ & $(-26.46)$ & $(2.54)$ & $(8.20)$ \\
\hline NOBS & 1,611 & 1,611 & 1,611 & 1,454 & 1,429 \\
\hline R-squared & 0.341 & 0.280 & 0.536 & 0.021 & 0.317 \\
\hline Power of the test & 1.000 & 1.000 & 1.000 & 0.9914 & 1.000 \\
\hline
\end{tabular}


Table 3.12 Multivariate Analysis for External CFO Appointment (All Firms)

In this table, I show the CFO replacement effect for a newly hired CFO from external sources. External is an indicator variable which takes a value of 1, if the hired CFO is from outside, and 0, if the hired CFO has been promoted. Both types of firms, good and distressed, are put together in this regression. Although post is significant under synchronicity and external is significant under the number of analysts and forecast dispersion, their interaction is not significant. Therefore, we cannot conclusively comment on the effect of CFO-type on a firm's information environment. The effects of other variables are in line with the expected signs outlined in Table 4. $t$-statistics are in parentheses. $* * *, * *$, and $*$ denote statistical significance at the $1 \%, 5 \%$, and $10 \%$ levels, respectively. The power of the test is computed by the G*Power 3 program by Faul et al. (2007).

\begin{tabular}{lccccc}
\hline & $\begin{array}{c}\text { Idiosyncratic } \\
\text { variance }\end{array}$ & Synchronicity & $\begin{array}{c}\text { Ln of no. of } \\
\text { analysts }\end{array}$ & $\begin{array}{c}\text { Forecast } \\
\text { errors }\end{array}$ & $\begin{array}{c}\text { Forecast } \\
\text { dispersion }\end{array}$ \\
\hline Post & 0.002 & $0.154^{* *}$ & -0.013 & 0.064 & 0.001 \\
External & $(1.45)$ & $(2.48)$ & $(-0.29)$ & $(1.29)$ & $(0.65)$ \\
& 0.001 & 0.045 & $0.083^{*}$ & -0.039 & $-0.002^{*}$ \\
Post*External & $(0.65)$ & $(0.70)$ & $(1.81)$ & $(-0.77)$ & $(-1.95)$ \\
& -0.002 & -0.013 & 0.000 & -0.116 & 0.000 \\
Ln of no. of analysts & $(-0.64)$ & $(-0.15)$ & $(0.01)$ & $(-1.60)$ & $(0.28)$ \\
& $0.003^{* * *}$ & 0.04 & & & \\
Insider holdings & $(3.65)$ & $(1.16)$ & & & \\
& -0.003 & $-0.275^{* * *}$ & $0.143^{* *}$ & -0.011 & $-0.003^{* *}$ \\
Institutional holdings & $-0.022^{* * *}$ & $0.484^{* * *}$ & $0.816^{* * *}$ & -0.078 & $-0.010^{* * *}$ \\
& $(-7.75)$ & $(4.55)$ & $(10.99)$ & $(-0.90)$ & $(-6.85)$ \\
Ln of market value & $-0.007^{* * *}$ & $0.217^{* * *}$ & $0.347^{* * *}$ & $-0.023^{*}$ & $-0.001^{* * *}$ \\
& $(-13.10)$ & $(11.41)$ & $(32.42)$ & $(-1.94)$ & $(-5.22)$ \\
ROA & $-0.015^{* * *}$ & 0.199 & $-0.640^{* * *}$ & $0.392^{* * * *}$ & $-0.027^{* * *}$ \\
& $(-3.66)$ & $(1.32)$ & $(-5.95)$ & $(3.16)$ & $(-12.32)$ \\
SD of ROA & $0.126 * * *$ & $-2.095^{* * *}$ & -0.084 & $-0.975^{*}$ & $0.044^{* * *}$ \\
& $(6.87)$ & $(-3.03)$ & $(-0.17)$ & $(-1.65)$ & $(4.35)$ \\
Constant & $0.193^{* * *}$ & $-5.616^{* * * *}$ & $-5.669^{* * *}$ & $0.644^{* * * *}$ & $0.036^{* * *}$ \\
& $(20.39)$ & $(-15.72)$ & $(-26.23)$ & $(2.63)$ & $(8.40)$ \\
NOBS & 1599 & 1599 & 1599 & 1454 & 1429 \\
R-squared & 0.341 & 0.28 & 0.536 & 0.021 & 0.317 \\
Power of the test & 1.000 & 1.000 & 1.000 & 0.991 & 1.000 \\
\hline & & & & & \\
\hline
\end{tabular}


Table 3.13 Multivariate Analysis for External CFO Appointment (-5 Years)

I divide CFO class to see whether CFO hire within the firm or outside the firm affects the firm's information environment differently, conditional on the fact that CFO change affects information environment (refer to Table 3.6). Propensity score matching is used to pick the same number of distressed and non-distressed firms. In the first stage, a logit regression was run in which an indicator variable (distressed firm $=1$ and sound firm $=0$ ) is used as dependent and the number of analysts, insider holdings, institutional holdings, market capitalization, earnings, and volatility of earnings risk are used as independent variables. In the second stage, the same procedure was followed as previously mentioned in Table 3.5. As expected, $\mathrm{CFO}$ change from external source matters more. Bringing a CFO from outside significantly improves information environment (analysts' forecast error is reduced significantly). The finding is consistent with Mian (2001). The power of the test is computed by the G*Power 3 program by Faul et al. (2007).

\begin{tabular}{|c|c|c|c|c|c|}
\hline & $\begin{array}{c}\text { Idiosyncratic } \\
\text { variance }\end{array}$ & Synchronicity & $\begin{array}{l}\text { Ln of no. } \\
\text { of analysts }\end{array}$ & $\begin{array}{l}\text { Forecast } \\
\text { errors }\end{array}$ & $\begin{array}{l}\text { Forecast } \\
\text { dispersion }\end{array}$ \\
\hline \multirow[t]{2}{*}{ Post } & 0.003 & 0.070 & $(0.009)$ & 0.086 & $(0.003)$ \\
\hline & $(0.70)$ & $(0.58)$ & $(-0.09)$ & $(0.66)$ & $(-0.82)$ \\
\hline \multirow[t]{2}{*}{ External } & $(0.007)$ & 0.147 & $(0.079)$ & 0.098 & $(0.005)$ \\
\hline & $(-1.44)$ & $(1.22)$ & $(-0.76)$ & $(0.76)$ & $(-1.36)$ \\
\hline \multirow[t]{2}{*}{ Post*External } & 0.000 & $(0.014)$ & $(0.078)$ & $-0.371 * *$ & 0.001 \\
\hline & $(-0.04)$ & $(-0.09)$ & $(-0.55)$ & $(-2.06)$ & $(0.180)$ \\
\hline \multirow[t]{2}{*}{ Ln of no. of analysts } & 0.001 & $(0.016)$ & & & \\
\hline & $(0.640)$ & $(-0.27)$ & & & \\
\hline \multirow[t]{2}{*}{ Insider holdings } & $(0.010)$ & $(0.086)$ & $0.590 * * *$ & $-0.435 * *$ & $(0.003)$ \\
\hline & $(-1.14)$ & $(-0.40)$ & $(3.25)$ & $(-2.27)$ & $(-0.57)$ \\
\hline \multirow[t]{2}{*}{ Institutional holdings } & $-0.035 * * *$ & $0.685 * * *$ & $0.753 * * *$ & 0.041 & $-0.021 * * *$ \\
\hline & $(-5.05)$ & $(3.910)$ & $(5.140)$ & $(0.210)$ & $(-3.89)$ \\
\hline \multirow[t]{2}{*}{ Ln of market value } & $-0.004 * *$ & $0.267 * * *$ & $0.377 * * *$ & $(0.041)$ & $(0.001)$ \\
\hline & $(-2.30)$ & $(6.840)$ & $(13.540)$ & $(-1.11)$ & $(-1.13)$ \\
\hline \multirow[t]{2}{*}{ ROA } & $(0.011)$ & 0.282 & $-0.533 * * *$ & $0.588 * * *$ & $-0.029 * * *$ \\
\hline & $(-1.46)$ & $(1.470)$ & $(-3.26)$ & $(2.690)$ & $(-5.20)$ \\
\hline \multirow[t]{2}{*}{$\mathrm{SD}$ of $\mathrm{ROA}$} & $0.089 * * *$ & $-1.517 *$ & $-1.608 * *$ & 0.044 & $(0.002)$ \\
\hline & $(2.600)$ & $(-1.75)$ & $(-2.16)$ & $(0.040)$ & $(-0.06)$ \\
\hline \multirow[t]{2}{*}{ Distressed } & $0.009 * * *$ & $-0.251 * * *$ & 0.069 & $(0.004)$ & $-0.005^{* *}$ \\
\hline & $(2.660)$ & $(-2.99)$ & $(0.950)$ & $(-0.04)$ & $(-2.22)$ \\
\hline \multirow[t]{2}{*}{ Constant } & $0.154 * * *$ & $-6.303 * * *$ & $-6.061 * * *$ & 0.986 & $0.052 * * *$ \\
\hline & $(5.560)$ & $(-8.99)$ & $(-11.58)$ & $(1.420)$ & $(2.930)$ \\
\hline NOBS & 402 & 402 & 402 & 346 & 336 \\
\hline R-squared & 0.197 & 0.341 & 0.499 & 0.052 & 0.232 \\
\hline Power of the test & 1.000 & 1.000 & 1.000 & 0.874 & 1.000 \\
\hline
\end{tabular}


Table 3.14 Multivariate Analysis for External CFO Appointment (-4 Years)

I divide CFO class to see whether CFO hire within the firm or outside the firm affects the firm's information environment differently, conditional on the fact that CFO change affects information environment (refer to Table 3.7). Propensity score matching is used to pick the same number of distressed and non-distressed firms. In the first stage, a logit regression was run in which an indicator variable (distressed firm $=1$, otherwise $=0$ ) is used as dependent and the number of analysts, insider holdings, institutional holdings, market capitalization, earnings, and volatility of earnings risk are used as independent variables. In the second stage, the same procedure was followed as previously mentioned in Table 3.5. In order to capture any effect due just being "distressed," I use the dummy variable distressed in the regression. Being only a distressed firm significantly increases market noise or idiosyncratic variance and reduces synchronicity. However, when a CFO is hired from an external source, the information environment (synchronicity) of the firm improves significantly. The finding is consistent with that of Mian (2001). The power of the test is computed by the G*Power 3 program by Faul et al. (2007).

\begin{tabular}{|c|c|c|c|c|c|}
\hline & $\begin{array}{c}\text { Idiosyncratic } \\
\text { variance }\end{array}$ & Synchronicity & $\begin{array}{l}\text { Ln of no. } \\
\text { of analysts }\end{array}$ & $\begin{array}{c}\text { Forecast } \\
\text { errors }\end{array}$ & $\begin{array}{l}\text { Forecast } \\
\text { dispersion }\end{array}$ \\
\hline \multirow[t]{2}{*}{ Post } & 0.004 & $(0.051)$ & $-0.157 *$ & 0.023 & $0.005 * *$ \\
\hline & $(1.230)$ & $(-0.54)$ & $(-1.89)$ & $(0.210)$ & $(2.170)$ \\
\hline \multirow[t]{2}{*}{ External } & 0.000 & 0.042 & $(0.116)$ & $(0.053)$ & 0.000 \\
\hline & $(-0.12)$ & $(0.440)$ & $(-1.39)$ & $(-0.49)$ & $(-0.04)$ \\
\hline \multirow[t]{2}{*}{ Post*External } & $(0.005)$ & $0.227 *$ & 0.126 & $(0.233)$ & $(0.005)$ \\
\hline & $(-0.95)$ & $(1.74)$ & (1.09) & $(-1.53)$ & $(-1.56)$ \\
\hline \multirow[t]{2}{*}{ Ln of no. of analysts } & $0.004 * *$ & 0.074 & & & \\
\hline & $(2.18)$ & (1.63) & & & \\
\hline \multirow[t]{2}{*}{ Insider holdings } & $(0.001)$ & $(0.113)$ & $0.291 * *$ & $(0.226)$ & $(0.002)$ \\
\hline & $(-0.17)$ & $(-0.74)$ & $(2.18)$ & $(-1.29)$ & $(-0.66)$ \\
\hline \multirow[t]{2}{*}{ Institutional holdings } & $-0.031 * * *$ & $0.661 * * *$ & $0.596 * * *$ & $(0.141)$ & $-0.016 * * *$ \\
\hline & $(-5.83)$ & $(4.720)$ & $(4.90)$ & $(-0.88)$ & $(-4.65)$ \\
\hline \multirow[t]{2}{*}{ Ln of market value } & $-0.004 * * *$ & $0.229 * * *$ & $0.381 * * *$ & 0.011 & $-0.002 * *$ \\
\hline & $(-3.13)$ & $(7.250)$ & $(16.350)$ & $(0.370)$ & $(-2.34)$ \\
\hline \multirow[t]{2}{*}{ ROA } & $-0.014 * *$ & $0.282 *$ & $-0.854 * * *$ & 0.246 & $-0.026 * * *$ \\
\hline & $(-2.28)$ & $(1.750)$ & $(-6.18)$ & $(1.320)$ & $(-6.44)$ \\
\hline \multirow[t]{2}{*}{ SD of ROA } & $0.082 * * *$ & $(0.998)$ & $-1.306^{* *}$ & (1.180) & $0.034 *$ \\
\hline & $(3.12)$ & $(-1.46)$ & $(-2.17)$ & $(-1.24)$ & $(1.83)$ \\
\hline \multirow[t]{2}{*}{ Distressed } & $0.005 * *$ & $-0.308 * * *$ & 0.092 & $(0.017)$ & $(0.002)$ \\
\hline & $(2.13)$ & $(-4.68)$ & $(1.59)$ & $(-0.23)$ & $(-1.00)$ \\
\hline \multirow[t]{2}{*}{ Constant } & $0.147 * * *$ & $-5.709 * * *$ & $-6.053 * * *$ & 0.096 & $0.050 * * *$ \\
\hline & $(6.74)$ & $(-10.02)$ & $(-13.75)$ & $(0.17)$ & $(3.97)$ \\
\hline NOBS & 632 & 632 & 632 & 538 & 530 \\
\hline R-squared & 0.166 & 0.323 & 0.437 & 0.031 & 0.258 \\
\hline Power of the test & 1.000 & 1.000 & 1.000 & 0.837 & 1.000 \\
\hline
\end{tabular}


Table 3.15 Multivariate Analysis for External CFO Appointment (-3 Years)

I divide CFO class to see whether CFO hire within the firm or outside the firm affects firm's information environment differently, conditional on the fact that CFO change affects information environment (refer to Table 3.8). Propensity score matching is used to pick the same number of distressed and non-distressed firms. In the first stage, a logit regression was run in which an indicator variable (distressed firm $=1$, otherwise $=0$ ) is used as dependent and the number of analysts, insider holdings, institutional holdings, market capitalization, earnings, and volatility of earnings risk are used as independent variables. In the second stage, the same procedure was followed as previously mentioned in Table 3.5. In order to capture any effect due to just being "distressed," I use the dummy variable distressed in the regression. Being only a distressed firm significantly increases market noise or idiosyncratic variance and reduces synchronicity. However, when a CFO is hired from an external source, the information environment (synchronicity) of the firm improves: two information environment variables are significant. The finding is consistent with that of Mian (2001). The power of the test is computed by the G*Power 3 program by Faul et al. (2007).

\begin{tabular}{lccccc}
\hline & $\begin{array}{c}\text { Idiosyncratic } \\
\text { variance }\end{array}$ & Synchronicity & $\begin{array}{c}\text { Ln of no. } \\
\text { of analysts }\end{array}$ & $\begin{array}{c}\text { Forecast } \\
\text { errors }\end{array}$ & $\begin{array}{c}\text { Forecast } \\
\text { dispersion }\end{array}$ \\
\hline Post & $0.005 *$ & 0.088 & $-0.130 *$ & 0.067 & -0.001 \\
External & $(1.82)$ & $(1.04)$ & $(-1.87)$ & $(0.75)$ & $(-0.38)$ \\
& -0.000 & 0.023 & -0.029 & 0.100 & $-0.004 * *$ \\
Post*External & $(-0.02)$ & $(0.27)$ & $(-0.42)$ & $(1.14)$ & $(-2.29)$ \\
& -0.005 & 0.029 & $0.161 *$ & $-0.319 * *$ & 0.002 \\
Ln of no. of analysts & $(-1.19)$ & $(0.25)$ & $(1.68)$ & $(-2.51)$ & $(0.95)$ \\
Insider holdings & $0.004 * * *$ & $0.076^{*}$ & & & \\
& $(2.73)$ & $(1.90)$ & & & \\
Institutional holdings & -0.006 & -0.136 & $0.232 * *$ & -0.179 & $-0.006 * *$ \\
Ln of market value & $(-1.43)$ & $(-1.02)$ & $(2.10)$ & $(-1.24)$ & $(-2.29)$ \\
& $-0.027 * * *$ & $0.344 * * *$ & $0.751 * * *$ & -0.204 & $-0.019 * * *$ \\
ROA & $(-6.34)$ & $(2.62)$ & $(7.13)$ & $(-1.41)$ & $(-6.89)$ \\
& $-0.006 * * *$ & $0.223 * * *$ & $0.366 * * *$ & $0.060 * *$ & $-0.001 * *$ \\
SD of ROA & $(-6.27)$ & $(7.96)$ & $(18.64)$ & $(2.28)$ & $(-2.44)$ \\
& $-0.014 * * *$ & 0.231 & $-0.770 * * *$ & 0.232 & $-0.024 * * *$ \\
Distressed & $(-2.64)$ & $(1.45)$ & $(-5.95)$ & $(1.40)$ & $(-7.67)$ \\
Constant & $0.058 * *$ & $-1.560 * *$ & -0.297 & -0.271 & $0.032 * *$ \\
NOBS & $(2.52)$ & $(-2.24)$ & $(-0.52)$ & $(-0.33)$ & $(2.33)$ \\
R-squared & $0.007 * * *$ & -0.084 & 0.049 & 0.073 & -0.001 \\
Power of the test & $(3.31)$ & $(-1.40)$ & $(0.98)$ & $(1.12)$ & $(-0.46)$ \\
& $0.181 * * *$ & $-5.639 * * *$ & $-5.940 * * *$ & $-0.996 * *$ & $0.047 * * *$ \\
& $(10.97)$ & $(-11.24)$ & $(-16.27)$ & $(-2.04)$ & $(5.21)$ \\
& 632 & 632 & 632 & 538 & 530 \\
& 0.215 & 0.244 & 0.451 & 0.029 & 0.264 \\
& 1.000 & 1.000 & 1.000 & 0.805 & 1.000 \\
\hline
\end{tabular}




\section{REFERENCES}

Ahern, K.R., 2009. Sample selection and event study estimation. Journal of Empirical Finance 16, 466-482.

Aier, K.J., Comprix, J., Gunlock, K.M., Lee, D., 2005. The financial expertise of CFOs and accounting restatements. Accounting Horizons 19, 123-135.

Aktas, N., DeBondt, E., Cousin, J-G., 2007. Event studies with a contaminated period. Journal of Corporate Finance 13, 129-145.

Alford, A., Berger, P., 1999. A simultaneous equation analysis of forecast accuracy, analyst following, and trading volume. Journal of Accounting, Auditing \& Finance 14, 219-246.

Armstrong, S.C., Jagolinzer, D.A., Larcker, F.D., 2010. Chief executive officer equity incentives and accounting irregularities. Journal of Accounting Research 48, 225-271.

Avramov, D., Chordia, T., Goyal, A., 2006. The impact of trades on daily volatility. The Review of Financial Studies 19, 1241-1277.

Balsam, S., Puthenpurackal, J., Upadhyay, A., 2016. The determinants and performance impact of outside board leadership. Journal of Financial and Quantitative Analysis, Forthcoming article. Abstract available at:

http://depts.washington.edu/jfqa/forthcoming.html

Barron, E.O., Kim, O., Lim, C.S., Stevens, D.E., 1998. Using analysts' forecasts to measure properties of analysts' information environment. The Accounting Review 73, 421-433.

Barron, E.O., Stuerke, S.P., 1998. Dispersion in analysts' earnings forecasts as a measure of uncertainty. Journal of Accounting, Auditing \& Finance 13, 245-270.

Barry, B.C., Jennings, H.R., 1992. Information and diversity of analyst opinion, Journal of Financial and Quantitative Analysis 27, 169-183.

Bebchuk, L., Cohen, A., Ferrell, A., 2009. What matters in corporate governance? The Review of Financial Studies 22, 1-45.

Bertrand, M., Schoar, A., 2003. Managing with style: The effect of managers on firm policies. The Quarterly Journal of Economics 118, 1169-1208.

Bhushan, R., 1989. Firm characteristics and analyst following. Journal of Accounting and Economics 22, 255-274.

Bonnier, K-A., Bruner R.F., 1989. An analysis of stock price reaction to management change in distressed firms. Journal of Accounting and Economics 11, 95-106. 
Brockman, P., Yan, X., 2009. Block ownership and firm-specific information. Journal of Banking and Finance 33, 308-316.

Ben-David, I., Graham, J.R., Harvey, C.R., 2010. Managerial miscalibration. Working Paper 16215 NBER Working Paper Series http://www.nber.org/papers/w16215

Billett, T.M., Garfinkel, A.J., Jiang, Y., 2011. The influence of governance on investment: Evidence from a hazard model. Journal of Financial Economics 102, 643-670.

Brettel, M., Kasch, M., Mueller, A., 2008. CFO overconfidence, optimism, and corporate financing. FMA Annual Meeting Paper, available at fma.org

Chan, K., Hameed, A., 2006. Stock price synchronicity and analyst coverage in emerging markets. Journal of Financial Economics 80, 115-147.

Chang, X., Dasgupta, S., Hilary, G., 2009. The effect of auditor quality on financing decisions. The Accounting Review 84, 1085-1117.

Chung, K.H., Elder, J. Kim, J.-C., (2010). Corporate governance and liquidity. Journal of Financial and Quantitative Analysis, 265-291.

Coffee, J., 2002. Racing towards the top? The impact of cross-listings and stock market competition on international corporate governance. Columbia Law Review 102, 17571831.

Cohen, J., 1988. Statistical power analysis for the behavioral sciences (2nd ed.). Hillsdale, NJ: Erlbaum

Cools, K., Van Praag, C.M., 2007. The value relevance of top executive departures: Evidence from the Netherlands. Journal of Corporate Finance 13, 721-742.

Cremers, M., Grinstein, Y., 2008. The Market for CEO Talent: Implications for CEO compensation. Available at: https://www.binghamton.edu/som/files/Cremers\%20\%20Grinstein\%20-\%20The\%20Market\%20for\%20CEO\%20Talent\%20\%20Sept\%202008.pdf.

Coyne, K.P., Coyne, E.J., 2007. Surviving your new CEO. Harvard Business Review, available at www.hbr.org.

Davison, R., Dey, A., Simth, A., 2013. Executives' "off-the-job" behavior, corporate culture, and financial reporting risk. Journal of Financial Economics, Article in the press.

Dechow, P.M., Ge, W., Larson, C.R, Sloan, R.G., 2011. Predicting material accounting misstatements. Contemporary Accounting Research, 28, 17-82.

Denis, D., Denis, D., 1995. Performance changes following top management dismissals. Journal of Finance 50 (4), 1029-1057. 
Dittmar A., Thakor, A., 2007. Why do firms issue equity? The Journal of Finance 62, 154.

Doidge, C., Karolyi, G.A., Lins, K., Miller, D., Stulz, R., 2009. Private benefits of control, ownership and the cross-listing decision. Journal of Finance 64, 425-466.

Errunza, V., Miller, D., 2000. Market segmentation and the cost of capital in international equity markets. Journal of Financial and Quantitative Analysis 35, 577-600.

Fama, F.E., French, R.K., 2005, Financing decisions: Who issues stock? Journal of Financial Economics 76, 549-582.

Faul, F., Erdfelder, E., Lang, A.G. Buchner, A., 2007. G* Power 3: A flexible statistical power analysis program for the social, behavioral, and biomedical sciences. Behavior research methods, 39, 175-191.

Favaro, K., Karlsson, P.-O., Katzenbach, J., Neilson, G., 2010. CEO succession 2000-2009: A decade of convergence and compression, Booz \& Company. Sponsored by the Chicago Booth Executive Education.

Fee, E.C., Hadlock, C.J., 2004. Management turnover across the corporate hierarchy. Journal of Accounting and Economics, 37, 3-38.

Ferdinand A. Gul, F.A, Srinidhi, B., Anthony, C. N., 2011. Does board gender diversity improve the informativeness of stock prices? Journal of Accounting and Economics 51 (2011) 314-338

Fernandes, N., Ferreira, A.M., 2008. Does international cross-listing improve the information environment? Journal of Financial Economics 88, 216-244.

Ferris, P.S., Jayaraman, N., Lim, J., 2014. Six decades of CEO successions: The importance of being an insider. 2014 FMA Annual Meeting Papers. Available at: http://www.fma.org/Nashville/NashProgram.htm.

Foucault, T., Gehrig, T., 2008. Stock price informativeness, cross-listings, and investment decisions. Journal of Financial Economics 88, 146-168.

Frank, M.Z., Goyal, V.K., 2009. Capital structure decisions: Which factors are reliably important? Financial Management Spring, 1-37.

Furtado, E., Rozeff, M., 1987. The wealth effects of company initiated management changes. Journal of Financial Economics 18, 147-160.

Geiger M.A., North D.S., 2006. Does hiring a new CFO change things? An investigation of changes in discretionary accruals. The Accounting Review 81, 781-809. 
Gilson, C.S., 1989. Management turnover and financial distress. Journal of Financial Economics 25, $241-262$

Gompers, P., Ishii, J., Metrick A., 2003. Corporate Governance and Equity Prices. Quarterly Journal of Economics 118, 107-55.

Graham, R.J., Harvey, C., 2001. The theory and practice of corporate finance: evidence from the field. Journal of Financial Economics 60, 187-243.

Graham, R.J., Harvey, R.C., Rajgopal, S., 2005. The economic implications of corporate financial reporting. Journal of Accounting and Economics 40 (2005) 3-73.

Grossman, S.J., Stiglitz, J.E., 1980. On the possibility of informationally efficient markets. American Economic Review 70, 393-408.

Greenwood, R., 2005. Aggregate corporate liquidity and stock returns. Working paper. Harvard University.

Gul, A.F., Srinidhi, B., Ng, C.A., 2011. Does board gender diversity improve the informativeness of stock prices? Journal of Accounting and Economics 51, 314-338

Hayes, R.M., Oyer, P., Schaefer, S., 2002. Stability of top management teams. Available at SSRN.

Hazarika S., Karpoff, M.J., Nahata, R., 2012. Internal corporate governance, CEO turnover, and earnings management Journal of Financial Economics 104, 44-69.

Herrmann, D., Kang, K., Yoo, K.Y., 2015. The impact of cross-listing in the United States on the precision of public and private information. Journal of International Business Studies 46, 87-103.

Hovakimian, A., Opler, T., Titman, S., 2001. The debt-equity choice. Journal of Financial and Quantitative Analysis 36, 1-24.

Hovakimian, A., Hovakimian, G., Tehranian. H., 2004. Determinants of target capital structure: The case of dual debt and equity issues. Journal of Financial Economics 71, $517-540$.

Huson, M., Parrino, R., Starks, L., 2001. Internal monitoring mechanisms and CEO turnover: a long-term perspective. Journal of Finance 56, 2265-2297.

Indjejikian R., Matejka., M., 2009. CFO fiduciary responsibilities and annual bonus incentives Journal of Accounting Research 47, 1061-1093.

Jiang, J., Petroni, K.R., Wang, I.Y., 2010. CFOs and CEOs: who have the most influence on earnings management? Journal of Financial Economics, 96, 513-526. 
Johnson, C.T. 2004. Forecast dispersion and the cross section of expected returns. The Journal of Finance 59, 1957-1978.

Jalal, A.M., Prezas, A.P., 2012. Outsider CEO succession and firm performance. Journal of Economics and Business 64, 399-426.

Jiang, J., Petroni, K.R., Wang, I.Y., 2010. CFOs and CEOs: Who have the most influence on earnings management? Journal of Financial Economics, 96, 513-526.

Li, C., Sun, L., Ettredge, M., 2010. Financial executive qualifications, financial executive turnover, and adverse SOX 404 opinions. Journal of Accounting and Economics, 50, 93110.

Lobo, L.G., Zhou, J., 2006. Did conservatism in financial reporting increase after the Sarbanes-Oxley act? Initial Evidence. Accounting Horizons 20, 57-73.

Matsunaga, R.S., Yeung, E.P., 2008. Evidence on the Impact of a CEO's Financial Experience on Quality of the Firm's Financial Reports and Disclosures. AAA 2008 Financial Accounting and Reporting Section (FARS) Paper. Available at http://papers.ssrn.com/sol3/papers.cfm?abstract_id=1014097\#\#.

McAnally, M., Weaver, C., Srivastava, A., 2008. Executive stock options, missed earnings targets and earnings management. The Accounting Review 83, 185-216.

McCloskey, D.N., Ziliak, S.T., 1996. The standard error of regressions. Journal of Economic Literature 34, 97-114.

Mian, S., 2001. On the choice and replacement of chief financial officers. Journal of Financial Economics 60, 143-175.

Miller, D., 1999. The market reaction to international cross-listings: evidence from Depositary Receipts. Journal of Financial Economics 51, 103-123.

Molina, A.C., 2002. Predicting bank failures using a hazard model: The Venezuelan banking crisis. Emerging Markets Review 3, 31-50.

Morck, R., Yeung, B., Yu, W., 2000. The information content of stock markets: Why do emerging markets have synchronous stock price movements? Journal of Financial Economics 58, 215-260.

Murphy, J.K., and Zábojník, J., 2003. Managerial capital and the market for CEOs. Unpublished Manuscript. University of Southern California.

Murphy, J.K., and Zábojník, J., 2004. CEO pay and appointments: A market-based explanation for recent trends. American Economic Review, Papers and Proceedings, 192-196. 
Myers, S., 1984. The capital structure puzzle. Journal of Finance 39, 575-592.

Myers, S.C., Majluf, N. S., 1984. Corporate financing and investment decisions when firms have information that investors do not have. Journal of Financial Economics 13 (June), 187-221.

Parrino, R., 1997. CEO turnover and outside succession: A cross-section analysis. Journal of Financial Economics 46, 165-197.

Piotroski, J.D., Roulstone, D.T., 2004. The influence of analysts, institutional investors, and insiders on the incorporation of market, industry, and firm-specific information into stock prices. Accounting Review 79, 1119-1151.

Richardson, S., Sloan, R., Soliman, M., Tuna, I., 2005. Accrual reliability, earnings persistence, and stock prices. Journal of Accounting and Economics 39, 437-85.

Shumway, T., 2001. Forecasting bankruptcy more accurately: a simple hazard model. The Journal of Business 74, 101-124.

Soyer, E., Hogarth, R.M., 2012. The illusion of predictability: How regression statistics mislead experts. International Journal of Forecasting 28, 695-711.

Spruance, L.S., Reid, E.J., Grace, M., Samore, M., 2004. Hazard ratio in clinical trials. Antimicrobial Agents and Chemotherapy Aug., 2787-2792.

Taylor, A.L., 2010. Why are CEOs rarely fired? Evidence from structural estimation. The Journal of Finance 65, 2051-2087.

Thomas, S., 2002. Firm diversification and asymmetric information: evidence from analysts' forecasts and earnings announcements. Journal of Financial Economics 64, 373-396.

Walker, D.M., Yost, K., 2008. Seasoned equity offerings: What firms say, do, and how the market reacts. Journal of Corporate Finance 14, 376-386.

Warner, J., Watts, R., Wruck, K., 1988. Stock-prices and top management changes. Journal of Financial Economics 20, 461-492.

Weisbach, M., 1988. Outside directors and CEO turnover. Journal of Financial Economics 20, 431-460.

Weisbach, M.S., 1995. CEO turnover and the firm's investment decisions. Journal of Financial Economics 37, 159-188. 


\section{APPENDIX: VARIABLE DEFINITIONS}

[Variables related to equity choice of a firm are taken from Chang et al. 2009 and Hovakimian et al. 2001]

CFO turnover: an indicator variable. It takes a value of 1 if a firm experienced CFO turnover in the current year, otherwise 0 .

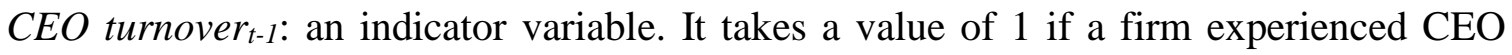
turnover in the previous year, otherwise 0 .

Return: it is defined as “firm's buy-and-hold stock return for the period ending at the start of the fiscal year during which the departure takes place less the value-weighted 2-digit compounded monthly industry return over this same period (Fee and Hadlock 2004, p.14)."

Ln of sales: natural log of annual sales

F-score: it calculates the probability of restating earnings and is calculated following Dechow et al. (2011).

Restatement: it is an indicator variable; takes a value of 1 if the firm restated earnings, otherwise 0. Restatement data is obtained from Audit Analytics.

Year: it is a trend or time variable. The starting year, 2004 was subtracted from the current year. Thus, it can be from $0(=2004-2004)$ to $11(=2015-2004)$.

Debt percent: Net debt issue/Beginning balance of assets $=($ Long Term Debt IssuanceLong Term Debt Reduction+ Current Debt Changes)/TAt-1 
Equity percent: Net equity issue/Beginning balance of assets= (Sale of Common and Preferred Stock- Purchase of Common and Preferred Stock)/TA 1 -1

Internal CFO (INTERNAL): A dummy variable taking a value of 1 if the hired CFO is promoted and has worked for the firm at least one year, 0 if the hired CFO worked for the company 0 year. The previous work experience of a CFO with the same company has been defined as the difference when his or her EXECID (executive ID) showed up in the EXECUCOMP dataset working for a firm and his or her appointment as a CFO. For new external hires, the year in which the ID first showed up and appointment year will be same, hence, the difference will be zero. In order to ensure that internal CFO has worked at least for one year for the appointing firm, I defined internal CFOs when year difference is greater than or equal to 2 (refer to Figure 2.1 for a graphical explanation). Title "CFO" includes, "chief financial officer," "CFO," "chief finance officer," "sr. exec.-finance," "vice president of finance," "principal financial officer," "chf. fin. Offr.," "V-P-finance," "VPfinance," "VP-strategy \& finance," "V-P-fin," “exec. fin. offr.," "sr. exec.-finance," and excludes "interim chief financial officer" "acting chief finance officer" "former chief finance officer" in the Annual Title column of EXECUCOMP dataset.

Industry $\mathrm{CFO}$ ratio: number of internal $\mathrm{CFO}$ appointments (excluding the sample firm) in a 2-digit SIC divided by the total number of firms in the industry in a year. It is used as an instrument.

Firm governance: it is proxied by the entrenchment index or e-index which implies the alignment (agreement) between firm's management and investors about the future payoffs of the projects. The index is calculated using Bebchuk, Cohen and Ferrell (2009): 


$$
E-\text { index }=\sum_{i=1}^{6} \text { EProvision }_{i}
$$

Which says that E-index is a sum of six entrenchment provisions. For the presence of each provision a value of 1 is assigned and 0 for the absence of the provision. The six entrenchment provisions are, "staggered board: a board in which directors are divided into separate classes (typically three) with each class being elected to overlapping terms, limitation on amending bylaws: a provision limiting shareholders' ability through majority vote to amend the corporate bylaws, limitation on amending the charter: a provision limiting shareholders' ability through majority vote to amend the corporate charter, supermajority to approve a merger: a requirement that requires more than a majority of shareholders to approve a merger, golden parachute: a severance agreement that provides benefits to management/board members in the event of firing, demotion, or resignation following a change in control, and poison pill: a shareholder right that is triggered in the event of an unauthorized change in control that typically renders the target company financially unattractive or dilutes the voting power of the acquirer" Bebchuk et al. 2009. The index value ranges from 0 to $6 ; 0$ being the absence of any entrenchment and 6 being high entrenchment toward investors. Highly entrenched firms have strong protection to remove or hold management accountable for their actions.

Ln of assets: Natural log of book value of assets.

Tangibility: Net PPE-to-Asset ratio.

Leverage ratio: Total debt/ (total assets + market value of equity - book value of equity). 
Market-to-Book ratio: (Total assets+ market value of equity- book value of equity)/ total assets.

Finance size: Total financing needs/ total assets $=($ net debt issued + net equity issued $) /$ total assets.

Share turnover: Median value of monthly shares traded (volume) divided by shares outstanding over a 12-month period.

Ln of firm age: Natural log of year difference between the first year the firm entered into COMPUSTAT database and current fiscal year.

Debt rating: Dummy variable if the firm has a debt rating assigned by Standard \& Poor's, and 0 otherwise.

Number of analyst: The maximum number of analysts making annual earnings forecasts at any month over a 12-month period. I assume firms that are not covered by I/B/E/S have zero analyst's coverage (Chang et al., 2009).

Volatility of earnings: Historical volatility using previous ten years of the ratio of EBITDA to total assets.

Volatility of stock returns: Standard deviation of the daily stock return calculated for each firm for each year.

Compounded stock return: Compounded annual stock returns over a twelve-month period.

Industry leverage ratio: The median industry leverage ratio is computed as the median of the ratio of total debt to the market value of assets by the 3-digit SIC code and by year. 
Number of analysts following: In previous research it is used as a control variable for information related dependent variables. I take the natural log of the number of analysts following because a small number of analysts follow small firms whereas a large number of analysts follow larger firms.

Institutional Holdings: I extract the variables from Thompson Reuters of Wharton Database (13f, s34 dataset). The database has three types of holding: direct institutional holding, indirect institutional holding and total institutional holding as a percentage of total stock outstanding. I use total holding by institutions such as mutual funds and other professional investment or money managers.

Insider Holdings: I extract the variables from Thompson Reuters of Wharton Database (TFN, Table \#1 dataset). It includes stock holding by the employees of the organization. I put "CEO," "COO," "CFO," “CB," “O," "D," "VP," and "P" as "rolecodes1" while extracting the data. It is defined as a percentage of total stock holdings.

Market Capitalization: Market price of a stock multiplied by the total shares outstanding. I take the natural logarithm of market capitalization.

Return on Assets (ROA): Income before extraordinary items divided by total assets.

Standard Deviation (SD) of ROA: Standard deviation of ROA is calculated using +/-12 quarterly ROA (Brockman et al. 2009) surrounding the CFO change date.

The following variables (used in calculation of F-score) are taken from Dechow et al. (2011) p.35-36: 
RSST accruals: RSST (Richardson, Sloan, Soliman and Tuna, 2005) accruals is calculated following Dechow et al. (2011). In their paper, it is calculated as, $(\Delta \mathrm{WC}+\Delta \mathrm{NCO}+\Delta \mathrm{FIN}) /$ Average total assets, where WC $=[$ Current Assets - Cash and Short-term Investments $]-$ [Current Liabilities - Debt in Current Liabilities $] ; \mathrm{NCO}=[$ Total Assets-Current AssetsInvestments and Advances ] - [Total Liabilities - Current Liabilities - Long-term Debt]. $\mathrm{FIN}=[$ Short-term Investments + Long-term Investments $]-[$ Long-term Debt + Debt in Current Liabilities + Preferred Stock].

$\Delta$ in receivables: $\Delta$ Accounts Receivable/Average total assets.

$\Delta$ in inventories: $\Delta$ Inventory/Average total assets.

Soft assets: (Total Assets- PP\&E-Cash and Cash Equivalent)/Total Assets.

$\Delta$ in cash sales: Percentage change in cash sales: Sales- $\Delta$ Accounts Receivable.

$\Delta$ in ROA: [Earningst/Average total assets $\mathrm{t}$ - [Earnings $\mathrm{t}_{\mathrm{t}-1} /$ Average total assets $\left.\mathrm{t}-1\right]$.

$\Delta$ in employees: Percentage change in the number of employees-percentage change in assets.

Lease dummy: An indicator variable coded 1 if the future operating lease obligations are greater than zero, otherwise 0 .

Issue: An indicator variable. It takes a value of 1 if the firm either issues long-term debt or equity, otherwise 0. 
VITA

BAKHTEAR TALUKDAR

Born, Jhalokati, Bangladesh

2004

B.B.A., Finance (Summa Cum Laude)

University of Dhaka

Dhaka, Bangladesh

2011

M.B.A., Finance (Ranked Third)

Willamette University

Salem, Oregon

2012-2016

Graduate Teaching Assistant

Florida International University

Miami, Florida

\section{PUBLICATIONS AND PRESENTATIONS}

Abdullah, Shahnaz, Chugh, Lal, and Talukdar, Bakhtear, 2014. "Do Female CEOs Add Value for Stockholders? A Case Study of Yahoo!" Journal of Finance and Accountancy Volume 16-Sept.

Mollah, Sabur and Talukdar, Bakhtear, 2007. "Ownership Structure, Corporate Governance, and Firm's Performance in Emerging Markets: Evidence from Bangladesh." The International Journal of Finance Volume 19(1): 4315-4333.

Market Return and Risk Factors for the Emerging Economies, with Ali M Parhizgari. 2015 FMA Annual Meeting, Orlando, FL and 2015 Global Finance Conference, Hangzhou, China, Apr. 24-26, 2015.

Financial Performance and Compensation Alignment of Male and Female CEOs, with Shahnaz Abdullah, and Lal Chugh. 80 ${ }^{\text {th }}$ International Atlantic Economic Conference, Boston, Oct. 8-11, 2015.

Executive Compensation and Firm Performance: Evidence from the Insurance Industry in the United States, with Deanne Butchey, Therese Pactwa, and Jerry Haar. 2014 Academy of Financial Services Conference, Nashville, Oct. 16-17, 2014.

Intraday Volume-Volatility Relationship in Pre and Post Decimalization Era, with Shahid Hamid and Rafiqul Bhuyan. 2014 Global Finance Conference, Dubai, UAE, Mar. 30-April $2,2014$.

Do Female CEOs Add Value for Stockholders? A Case Study of Yahoo!, with Shahnaz Abdullah, and Lal Chugh. 2014 Academy of Finance Conference, Chicago, March 26-28, 2014. 